Please note: This is a preprint for an article accepted for publication with PSPB. It may be subject to editing and other changes.

\title{
The nature of Islamophobia: A test of a tripartite view in five countries
}

\author{
Fatih Uenal ${ }^{1,2^{*}}$, Robin Bergh ${ }^{1}$, Jim Sidanius ${ }^{1}$, Andreas Zick ${ }^{3}$, Sasha Kimel ${ }^{4}$, and Jonas R. Kunst ${ }^{5,6}$ \\ ${ }^{1}$ Department of Psychology, Harvard University \\ ${ }^{2}$ Department of Psychology, University of Cambridge \\ ${ }^{3} \mathrm{IKG}$, University of Bielefeld \\ ${ }^{4}$ Department of Psychology, California State University San Marcos \\ ${ }^{5}$ Department of Psychology, University of Oslo \\ ${ }^{6}$ Center for research on extremism, University of Oslo \\ *Corresponding author
}

Please direct correspondence to Dr. Fatih Uenal, Department of Psychology, University of Cambridge, Old Cavendish Building, Free School Lane, CB2 3RQ, Cambridge, UK, E-mail:

\section{fu212@cam.ac.uk}

Word count: 9999 (Excluding title page, tables and figures)

Conflict of Interest: None

Ethical Approval: This Study partly was approved by Harvard University-Area Committee on the Use of Human Subject (IRB 16-1810).

Data Sharing: Please contact the PI for data accessibility.

Preregistration: asPredicted \#20961 (http://aspredicted.org/blind.php?x=6sk9gm)

Acknowledgements: The research was supported, in part, by a post-doctoral stipend from the Humboldt University Berlin within the Excellence Initiative of the states and the federal government (German Research Foundation). We also want to thank the reviewers and editor for their helpful comments. 


\begin{abstract}
This article provides an examination of the structure of Islamophobia across cultures. Our novel measure - the Tripartite Islamophobia Scale (TIS) - embeds three theoretically and statistically grounded subcomponents of Islamophobia: anti-Muslim prejudice, anti-Islamic sentiment, and conspiracy beliefs. Across six samples (i.e., India, Poland, Germany, France, and the USA), preregistered analyses corroborated that these three subcomponents are statistically distinct. Measurement invariance analyses indicated full scalar invariance, suggesting that the tripartite understanding of Islamophobia is generalizable across cultural contexts. Further, the subcomponents were partially dissociated in terms of the intergroup emotions they are predicted by as well as the intergroup outcomes they predict (e.g., dehumanization, ethnic persecution). For example, intergroup anger and disgust underpin Islamophobic attitudes, over and above the impact of fear. Finally, our results show that SDO and ingroup identification moderate intergroup emotions and Islamophobia. We address both theoretical implications for the nature of Islamophobia and practical interventions to reduce it.
\end{abstract}

Keywords: Fear, Anger, Disgust, Islamophobia, Measurement-Invariance 


\section{The nature of Islamophobia: A test of a tripartite view in five countries}

A growing number of people in the West view Islam and Muslims negatively (e.g., Gallup, 2013). According to a recent survey, 55\% of Europe's population agreed that migration from predominantly Muslim countries should be stopped (Goodwin, Rains, \& Cutts, 2017). Similarly, Muslims are the least favorably viewed, and most dehumanized, religious group in the USA (Kteily, Bruneau, Waytz, \& Cotterill, 2015; PEW, 2017), with outcomes ranging from institutional discrimination (e.g., "Muslim Ban") to hate crimes (e.g., Elahi \& Khan, 2017). In many parts of the world, Muslims also face arbitrary detention, forced sterilization, torture, and ethno-religious “cleansing” (HRW, 2018; UN, 2018).

Yet, despite the prevalence of Islamophobia - commonly used to refer to negative attitudes, emotions, and behaviors towards the Islamic religion and Muslims - no agreed-upon operationalization of the term exists (e.g., Bleich, 2011, Helbling, 2012; Klug, 2012; Uenal, 2016a). This absence is reflected in researchers' use of disparate items and scales (e.g., Imhoff \& Recker, 2012; Lee, Reid, Short, Gibbons, Yeh, \& Campbell, 2013). Moreover, to the best of our knowledge, these measurement approaches have not been validated cross-culturally. Crucially, due to this dearth of cross-cultural validation, the extent to which Islamophobia's dimensionality is generalizable across contexts remains unknown (Bleich, 2011; Küntzl, 2008; Uenal, 2016a; but see Kunst, Sam, \& Ulleberg, 2013 for perceived Islamophobia). Furthermore, Islamophobia's underlying emotional origins, psychological mechanisms, and its consequences remain understudied (e.g., Choma, Hodson, \& Costello, 2012; Choma, Haji, Hodson, \& Hoffarth, 2016; Uenal, 2016a, 2016b, 2017c).

In this paper, we propose, and cross-culturally validate, a tripartite view of Islamophobia, which differentiates between psychologically distinct components. Importantly, we also address 
a current debate over whether Islamophobia is primarily fear-based or, instead, whether it is better explained as socio-functional threat-based psychological reactions of anger and/or disgust to a social group, in addition to fear (e.g., Ketelaar, 2015; Neuberg \& Schaller, 2016; Park, Schaller, \& Crandall, 2007; Plutchik, 1980). Finally, we test two individual difference variables (social dominance orientation and ingroup identification), which might explain why some individuals react with fear while others display anger and/or disgust in response to Islam and Muslims (e.g., Choma et al., 2016; Matthews \& Levin, 2012). Thus, this paper aims to advance research on the nature of Islamophobia by addressing persistent theoretical and methodological issues including Islamophobia's conceptualization, measurement, cross-cultural validity, emotional origins, and societal consequences.

\section{What constitutes Islamophobia?}

Most commonly, Islamophobia is defined as negative, fear-based attitudes and behaviors towards Islam and its adherents - Muslims (e.g., Bangstadt, 2016; Conway, 1997; Bleich, 2011; Halliday, 1999; Klug, 2012). Accordingly, prominent measures of Islamophobia conflate items pertaining to both Islam (religious concept) and Muslims (social group; e.g., Imhoff \& Recker, 2012; Helbling, 2012; Lee et al., 2013). Yet, we argue that this comes with several interrelated caveats.

\section{Conflating Individuals and Concepts: Theoretical and Methodological Concerns}

In the social psychological literature, stereotyping, prejudice, and discrimination primarily refer to biases towards individuals based on their membership in a group and not towards the cultures, religions, institutions, or ideologies that individuals are a part of (e.g., Allport, 1954; Brown, 2010). In other words, traditional bias measures assess attitudes towards members of social groups (e.g., Jews, Atheists), not the abstract concept the group is adhering to 
(e.g. Judaism, Atheism). Importantly, research suggests that individuals are evaluated more positively than their larger impersonal representations (sometimes referred to as a personpositivity bias; e.g., Sears, 1983). For example, political party leaders (individuals) are more positively evaluated than the political institution they are part of (i.e., Nilsson \& Ekehammar, 1987). Indeed, previous research indicates that Muslims are more positively evaluated than their less personal representations (e.g., Islam; Leibold \& Kühnel, 2006). However, whereas modern measures of negativity towards Jews and Judaism differentiate between evaluation of its members (anti-Semitism) and its religion (anti-Judaism); Bilewicz \& Krzeminski, 2010; Bilewicz, Winiewski, Kofta, \& Wójcik, 2013), measures of Islamophobia do not.

Although it may seem reasonable to assume that individuals holding negative sentiments towards the Islamic religion are likely to also be biased against Muslims (Klug, 2012; Miles \& Brown, 2003), this relationship remains understudied (Uenal, 2016a). Furthermore, the conflation between Muslims and Islam has also triggered a heated debate about the comparability of Islamophobia with other types of prejudices like anti-Semitism (e.g., Bangstad, 2016; Bleich, 2011; Küntzl, 2008). In order to address this, here, we explicitly examine both attitudes about Muslims (individuals) and Islam (religious concept). We expect them to be statically distinguishable.

\section{A Secret Islamization of the West: Integrating Islamophobic Conspiracy Beliefs}

Another key component of Islamophobia - Islamophobic conspiracy beliefs - also remains understudied and has not yet been integrated into current conceptualizations and measurements (O’Donnell, 2018; Swami, Barron, Weis, \& Furnham, 2017; Uenal, 2016b). The belief in an Islamic conspiracy or a secret and ongoing "Islamization of the Western world" (e.g., Hafez, 2013) shows resemblance to anti-Semitic narratives (e.g., Zia-Ebrahimi, 2018) and is 
propelled by the idea of a demographic threat (e.g., Schiffer \& Wagner, 2011). Some believers claim that there is a well-orchestrated campaign (e.g., "EURABIA") to impose Islamic practices on the West. Such beliefs can have highly consequential outcomes. Indeed, they inspired the Norwegian terrorist, Anders Behring Breivik, to kill 77 people (Fekete, 2012; Uenal, 2016c). Belief in conspiracies has been shown to be distinct from stereotypes or prejudices (Abalakina-Paap, Stephan, Craig, \& Gregory, 1999; Moscovici, 1987). They are also uniquely associated with negative psychological and behavioral outcomes (Bilewicz \& Krzeminski, 2010), including political violence (Bartlett \& Miller, 2010), and they show strong associations with anxiety, uncertainty, and a perceived lack of control (e.g., van Prooijen \& Douglas, 2018; Whitson \& Galinsky, 2008). Notably, in the context of anti-Semitism, Bilewicz and colleagues (2013) showed that conspiracy beliefs predicted discriminatory behavioral intentions, above and beyond prejudice alone. Based on this, we expect conspiracy beliefs to be statistically distinct from anti-Muslim prejudice and anti-Islam sentiment, to uniquely predict discriminatory attitudes and behaviors, and to be primarily associated with intergroup fear.

\section{Emotional Underpinnings of Islamophobia: Who is Afraid of Islam?}

Another understudied issue regards Islamophobia's emotional underpinning. Closely resembling concepts like Homophobia and Xenophobia, Islamophobia has been conceptualized from a standard social psychological research perspective, which puts fear and uncertainty about outgroups at the heart of the prejudiced mindset (e.g., Adorno, Frenkel-Brunswick, Levinson, \& Sanford, 1950; Jost, Glaser, Kruglanski, \& Sulloway, 2003; Wilson, 1973). This fear-primacy axiom is derived from research on the authoritarian character and the conservative mind more generally, which posits that political conservatism is embraced as an ideology because of its fear, anxiety, and uncertainty reducing qualities (Sibley \& Duckitt, 2008; Jost et al., 2003). Indeed, the 
most frequently cited psychological definitions of Islamophobia hypothesizes that fear is its main affective component (e.g., Conway, 1997; Lee et al., 2013). Yet, despite these claims, the role of fear in Islamophobia has not been systematically explored.

A socio-functional threat-based perspective on prejudice argues that different social groups can elicit different social threat perceptions, which in turn motivate specific attitudinal, emotional, and behavioral reactions to effectively mitigate perceived threats (e.g., Neuberg \& Schaller, 2016; Park, Schaller, \& Crandall, 2007). For instance, Choma and colleagues (2012, 2016) have shown that intergroup disgust sensitivity is a robust predictor of Islamophobia. Given this, a socio-functional perspective may be better suited to understanding Islamophobia than focusing on fear alone. However, no previous studies have systematically analyzed multiple negative emotions (i.e., fear, disgust, and anger) concurrently and, thus, the emotional bases of Islamophobia and its subdimensions remain unclear.

\section{Fear, Anger \& Disgust: The Potential Moderating Role of Social Dominance Orientation and Ingroup Identification}

A further understudied question is whether individual differences modulate the emotional reactions underlying Islamophobia (e.g., Choma et al., 2016; Matthews \& Levin, 2012). Previous research has shown that group-based emotions can toggle between fear, anger, and/or disgust depending on a variety of other factors, including individual differences (for an overview see, Mackie \& Smith, 2015) such as ingroup identification (e.g., Mackie, Devos, \& Smith, 2000) and social dominance orientation (i.e., SDO; Pratto, Sidanius, Stallworth, \& Malle, 1994). In many Western countries, Muslims and Islam are highly salient categories, frequently associated with negative connotations such as ideological/value conflicts, terrorism as well as with realistic threats (e.g., to countries' welfare systems; Bleich, 2011; Uenal, 2016a). Thus, individuals highly 
identified with their ingroup and/or high in SDO may be more likely to perceive Muslims and Islam as threatening, albeit accompanied with differing emotional reactions.

A significant body of research shows that negative outgroup affect is robustly predicted by SDO across various intergroup contexts (e.g., Sidanius, Cotterill, Sheehy-Skeffington, Kteily, \& Carvacho, 2017). Individuals high in SDO are concerned with the maintenance of social hierarchies in general and are especially averse to low-status groups (e.g., Sibley \& Duckitt, 2008; Levin \& Sidanius, 1999). Importantly, some studies indicate that individuals high in SDO react with more anger and disgust, rather than fear, towards subordinate outgroups (e.g., Kossowska et al., 2008; Matthews \& Levin, 2012) that are perceived to threaten the existing hierarchical order (Thomsen, Green, \& Sidanius, 2008). More specifically, for individuals high in SDO, when Muslims and Islam are perceived as threating, anger and disgust should be amplified in order to reinforce boundaries and preserve the hierarchical arrangement of society since these emotions are associated with behavioral tendencies which help facilitate actions to mitigate potential threats through aggressive means. Thus, anger and disgust are more reflective of a high SDO mindset towards threatening outgroups (e.g., Matthews \& Levin, 2012; Sibley \& Duckitt, 2008) while, for individuals low in SDO, given their more egalitarian worldview, the effects of existing anger and disgust should be buffered.

Another such variable that might explain individual differences in emotional reactions towards ethno-religious minorities is ingroup identification. Individuals who are highly identified with their ingroup tend to be more concerned about the well-being and distinctiveness of their own group and, in turn, more sensitive to ethnic/religious minority groups as potential threats (e.g., Riek, Mania, \& Gaertner, 2006) and more likely to react with negative intergroup affect (e.g., Mackie, Devos, \& Smith, 2000). The relationship between ingroup identification and 
specific emotional reactions seems less clear-cut than with SDO and has been shown to vary in conjunction with further variables such as perceived collective support (Dumont, Yzerbyt, Wigboldus, \& Gordijn, 2003; Mackie, Devos, \& Smith, 2000). Thus, the specific affective response might vary independently of the strength of identification. Importantly, however, ingroup identification has been primarily linked to increased ingroup preference and love rather than outgroup derogation and aggression per se (Brewer, 1999; Levin \& Sidanius, 1999). Thus, Muslims and Islam might trigger protective strategies to increase feelings of ingroup distinctiveness and facilitate ingroup solidarity. Against this background, it seems reasonable to assume that high ingroup identification might primarily moderate feelings of fear and disgust towards Islam and Muslims, such that higher fear and disgust might interact with higher ingroup identification as a means to signal ingroup distinctiveness and solidarity via outgroup derogation while, for individuals with low ingroup identification we expect that group-based fear and disgust might be less salient due to low group-based concern.

\section{Overview of Studies}

We had three main goals, which we tested across two studies, the first of which included five separate samples. First, to the best of our knowledge, there are no cross-national tests of the structure of Islamophobia. Thus, our first goal was to fill this research gap by cross-culturally validating our novel Islamophobia measure across five different contexts (i.e., USA, India, Germany, France, Poland). These five contexts were selected because they differ in characteristics such as culture, level of economic prosperity, relative size of Muslim population, history of conflict, and levels of immigration - all factors that may contribute to different understandings (i.e., measurement structures) of Islamophobia. Here, particularly analytic attention was given to testing the cross-cultural equivalence (or measurement invariance [MI]) of 
the scale or "whether or not, under different conditions of observing and studying phenomena, measurement operations yield measures of the same attribute" (Horn \& McArdle, 1992, p. 117). Next, despite assumptions about fear in particular underlying Islamophobia, to our knowledge, this has also not been directly investigated. Thus, our second goal was to test the relationship of our measure with the intergroup emotions of fear, anger, and disgust. Given the cross-cultural nature of the present research, we were able to test whether the same emotions underpin Islamophobia across cultures.

In Study 2, we aimed to further investigate the relationship between intergroup emotions and Islamophobia by analyzing the role of two individual difference variables as potential moderators of this relationship in the USA We also aimed to further gauge the scale's psychometric qualities by testing its incremental validity. Here, we predicted that the Tripartite Islamophobia Scale (TIS) would predict negative intergroup outcomes such as dehumanization and ethnic persecution above and beyond well-established predictors. Furthermore, based on insights gained from research on anti-Semitism (e.g., Bilewicz \& Krzeminski, 2010), we expected that the sub-components of anti-Muslim prejudice and conspiracy belief would predict our criterion variables over and above anti-Islam sentiment.

For each study, the required sample sizes were calculated via power analyses (G*Power, Faul et al., 2009) for each statistical analysis individually to meet an $80 \%$ chance to observe a small to medium effect $\left(f^{2}=.04-f^{2}=.05\right)$. Detailed power analyses calculations for each statistical analysis are included in SOM (S1). All measures, conditions, quality checks, and data exclusions are reported in the respective method sections and in the SOM (see Tables S1-S4). 
NATURE OF ISLAMOPHOBIA

\section{Study 1}

\section{Methods}

Participants. The present study was pre-registered (see

http://aspredicted.org/blind.php? $\mathrm{x}=6 \mathrm{sk} 9 \mathrm{gm})$. We aimed to collect 300 participants in each country (for power analyses, see S1 in SOM). In the USA $(n=295)$ and India $(n=293)$, the data were collected via Amazon MTurk. In Germany $(n=293)$, Poland $(n=297)$, and France $(n=$ 288), the data were collected via the online participant recruitment service PROLIFIC. All samples were drawn between March and April 2019. The sample was $44.9 \%$ female and the average age was $36.4(S D=12.24)$. Detailed descriptive statistics for each country are provided in the SOM (Tables S1-S5).

\section{Instruments.}

Tripartite Islamophobia Scale (TIS). Based on a preliminary study (Uenal, 2016c) and a review of existing academic and non-academic literature, 25 items were adapted and/or developed to measure the three proposed subcomponents of Islamophobia. This item selection was subsequently presented and discussed in various research labs in the USA, Germany, Austria, Poland, and France and with leading academic researchers in Islamophobia studies. This led to making further adjustments and selecting 15 items in total. The final items were translated into English, Polish, and French from German and back-translated by native speakers and/or professional translators (see Tables S14-S15 SOM for all translations). As discussed in the introduction, the TIS was designed to capture three distinct aspects of beliefs and attitudes about Muslims and Islam (see Table S3 SOM). Cronbach's alphas were satisfactory for each country and are listed in the SOM (see Table S4). Anti-Muslim prejudice (average $\alpha=.91$ ), anti-Islam sentiment (average $\alpha=.91$ ) Islamophobic conspiracy beliefs (average $\alpha=.95$ ), and TIS 
aggregated scale (average $\alpha=.93$ ), were each measured with five items (see Figure 1). These items were measured on a five-point scale ranging from 1 (definitively false) to 5 (definitively true). In addition to the scale, participants completed the following measures assessed on 5-point scales ranging from 1 (strongly disagree) to 5 (strongly agree), unless otherwise noted.

Intergroup emotions. The intergroup emotions of fear, anger, and disgust were assessed with four items each framed toward Muslims and four corresponding items framed towards Islam (e.g., "I feel fearful when I think about Muslims [Islam]," "I feel repelled when I think about Muslims [Islam]," "I feel angry when I think about Muslims [Islam]"; Mackie, Devos, \& Smith, 2000). Due to length considerations, for the main analysis, we computed three variables, representing Fear of Muslims and Islam (average $\alpha=.97$ ), Anger toward Islam and Muslims (average $\alpha=.97$ ), and Disgust toward Islam and Muslims (average $\alpha=.97$ ). Additional analyses analyzing each emotion relating either to Islam or Muslims individually, showed no overall differences and are provided in the SOM (for correlation analysis see: Table S5; for regression analyses see: Tables S6-S7).

Analysis of data. We first ran Confirmatory Factor Analyses (CFA) in each country to test the proposed tripartite factor structure of Islamophobia. To this end, we tested if a threefactor model would fit the data better than a one-factor model, or theoretically justifiable twofactor models, in each analyzed country individually as well as in the overall sample. Next, we conducted multi-group measurement invariance analysis to test whether the proposed Tripartite Islamophobia Scale (TIS) showed cross-cultural equivalence. We then proceeded with the analysis of the emotional underpinnings of Islamophobia. We tested whether fear, anger, or disgust would be most predictive of our scale, by running multiple regression analyses and relative weights analysis (Tonidandel \& LeBreton, 2015). 
NATURE OF ISLAMOPHOBIA

\section{Results}

Descriptive statistics. Table 1 shows the mean scores, standard deviations, and intercorrelations among the intergroup emotion variables and the Islamophobia subscales for the overall aggregate sample.

Table 1

Means, Standard Deviations, and Intercorrelations Between all Variables Across Samples.

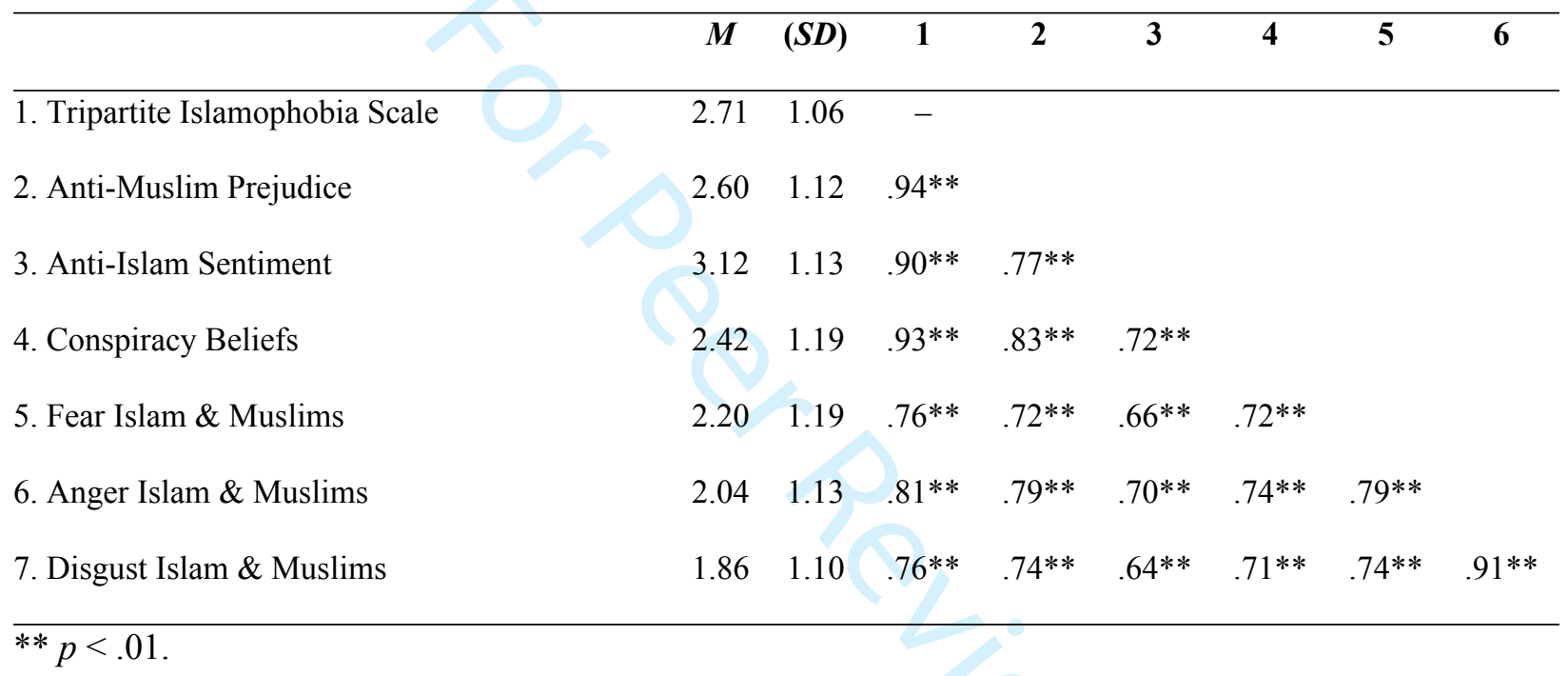

\section{Factorial structure and measurement equivalence.}

Confirmatory factor analysis. All CFAs were calculated using lavaan version $0.5-23$ in R (Rosseel, 2012). A test of normality of the latent variables indicated a non-normal distribution. We, therefore, employed the Satorra-Bentler rescaling method for CFA estimation, as suggested by Rosseel (2012).

For the overall aggregate sample, the results revealed that the proposed three-factor solution yielded good fit to the data, $\chi^{2} / d f=5.16 ; C F I=.98 ; T L I=.98 ; S R M R=.029 ; R M S E A$ $=.045$ with $90 \%$ CI $[.041-.050]$; and $A I C=54336.215$, and indeed better than a one-factor, 
$\chi^{2} / d f=18.85 ; C F I=.93 ; T L I=.91 ; S R M R=.48 ; R M S E A=.096$ with $90 \%$ CI $[.092-.100] ;$ and

$A I C=55509.398$, and all possible two-factor solutions (see SOM Table S9). Next, the threefactor model also yielded better results for each country individually (see Tables S8-S9 in the $\mathrm{SOM}$ ). Figure 1 depicts the results of a CFA with the confirmed three-factor structure for the overall aggregate sample.

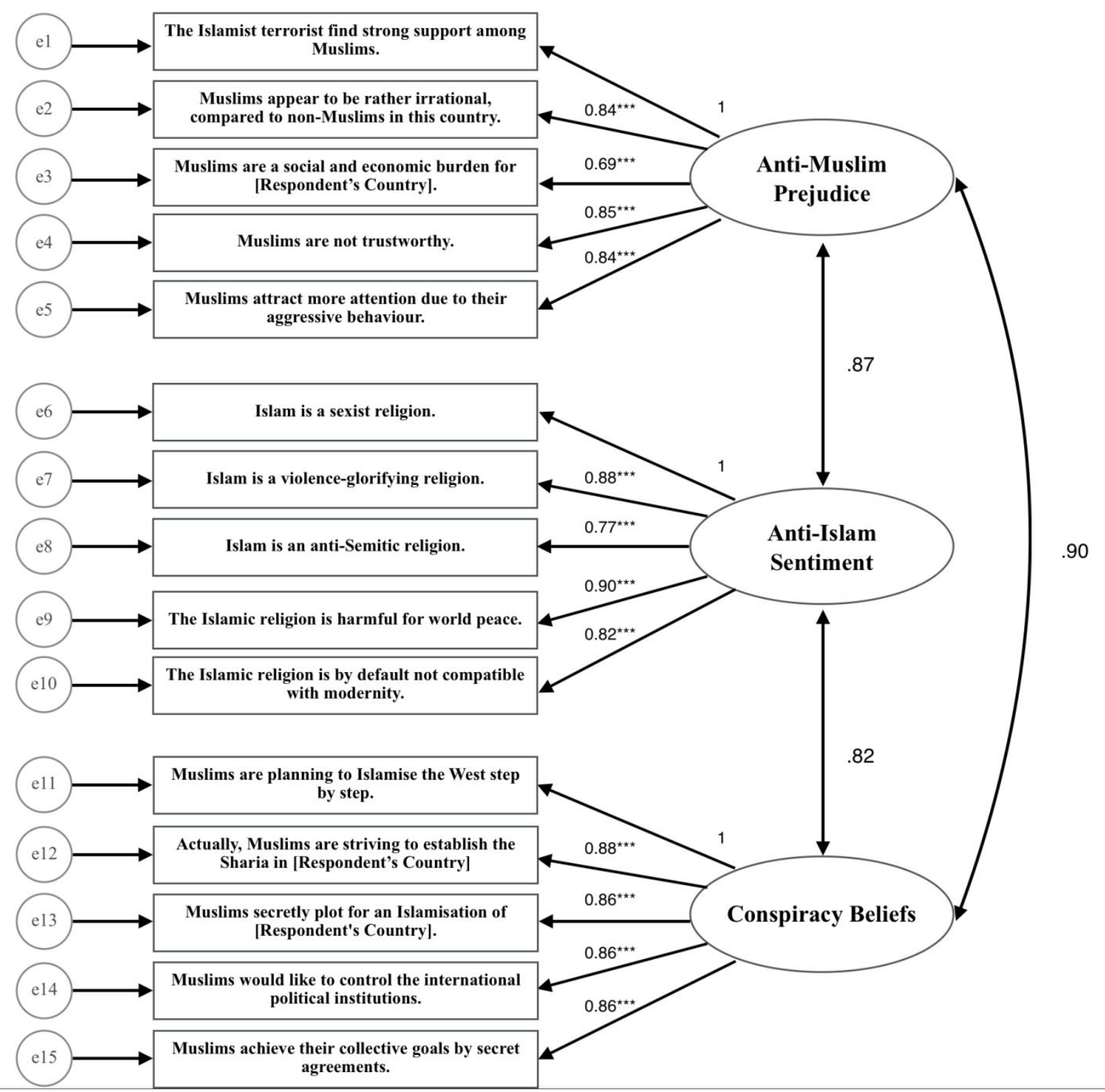

Figure 1. The three-factor measurement model of the Tripartite Islamophobia Scale. The numbers are 
standardized factor loadings as estimated in a configural model with no constraints. The model $\chi^{2}$ of 719.837 indicates a lack of an absolute fit $(p<.001)$, which is not uncommon for larger sample sizes $(N=$ 1466). However, all the other fit measures indicate that the model has a good model fit: $\chi^{2} / d f=5.16$; $C F I$ $=.98 ; T L I=.98 ;$ SRMR $=.029 ;$ and $R M S E A=.045$ with $90 \%$ CI $[.041-.050]$.

Measurement invariance analysis. Next, we tested whether our Islamophobia measure was cross-culturally equivalent by examining measurement invariance (MI) across the five samples. The primary objective was to ensure that the measurement models conducted under different conditions (geography, population, culture) yielded equivalent representations of the same construct (Jöreskog, 1971). The process of establishing MI includes six stages of analysis in total, of which only the first three steps are reported here due to space limitations (Steenkamp \& Baumgartner, 1998). For further details on additional analysis (i.e., bi-factor model, secondorder model), see caption of Table 2. By assessing whether factor loadings, intercepts, and residual variances are equivalent in a multi-group factor model (i.e., testing whether we measure the same underlying construct across the different contexts), we aimed to assure that comparisons that are made on our Islamophobia measure are valid across groups. If the first three levels of invariance - configural (same factor structure), metric (same factor loadings), and scalar (same intercept loadings) - across groups are met, comparison of the construct and item means across countries are justified. For comparison of effects, however, only the first two levels of invariance are required. Following Steenkamp and Baumgartner (1998), we adopted a "bottom-up" test strategy.

Chi-square difference tests are generally recommended to test for MI by comparing nested models. However, the $\chi^{2}$ difference test is influenced by sample size, almost always being significant in large samples (Chen et al., 2007). Therefore, we adopted a change in CFI between nested models of $\geq 0.010$ in addition to a change in the $R M S E A$ of $\geq 0.015$ or a change in $S R M R$ 
of $\geq 0.030$ (for loading invariance) and $\geq 0.010$ (for intercept invariance) as an appropriate criterion indicating a significant decrement in fit between models following Chen et al. (2007). However, Chen et al. (2007) suggested primarily using the change in CFI among the three indices for nested model comparisons as the other two are also affected by sample size.

Table 2

Multiple-Group Confirmatory Factor Analysis: Fit Measures and Differences of the Invariance Analysis.

\begin{tabular}{lllllllll}
\hline Model & \multirow{2}{*}{$\chi^{2}(d f)$} & $\boldsymbol{\Delta} \chi^{2}$ & CFI & $\Delta$ CFI & RMSEA & $\Delta$ RMSEA & SRMR & $\Delta$ SRMR \\
\hline Configural invariance & $909.198(410)$ & - & .980 & - & 0.051 & - & 0.036 & - \\
Full metric invariance & $989.972(458)$ & $80.77^{* * *}$ & .977 & 0.003 & 0.051 & 0.000 & 0.054 & 0.018 \\
Full scalar invariance & $1171.276(506)$ & $144.20^{* * *}$ & .970 & 0.010 & 0.056 & 0.005 & 0.058 & 0.022
\end{tabular}

Notes. Robust SEM Model-fit (Satorra-Bentler correction; Mplus Variant). $d f$-degrees of freedom; $C F I$ - comparative fit index; delta CFI - difference in CFI from the previous model in the sequence; RMSEA root mean square error of approximation, $S R M R$ - standardized root mean square residual.

*** significant at $p<0.01$.

Additionally, we also tested an alternative approach to the first-order factor measurement invariance analysis by also testing a second-order measurement invariance analysis and a bifactor model of our scale as comparisons. The results indicate that the fit of the first-order and second-order solutions fit the data equally good and better than the bifactor models. Results can be obtained by contacting the author.

Table 2 shows the results of a multi-group confirmatory factor analysis (MGCFA). The relative differences in $C F I$ and RMSEA between the three models were below the required threshold of $C F I_{\text {difference }} \geq 0.010$ and $R M S E A_{\text {difference }} \geq 0.015$ (i.e., suggesting that they have equivalent fit to the data), indicating configural invariance, full metric invariance, and full scalar invariance. As a result, group comparison can be made on valid grounds. 
Emotional underpinnings of Islamophobia. Having established cross-cultural equivalence at the metric level, the data further enabled us to test whether our Islamophobia measure is primarily associated with intergroup fear - as proposed by the most commonly referenced definitions (e.g., Conway, 1997; Lee et al., 2013) - or also by the intergroup emotions anger and/or disgust, as implicated by a socio-functional perspective (e.g., Neuberg \& Schaller, 2016). To this end, we proceeded by testing whether fear, anger, and disgust are uniquely and significantly predictive of Islamophobia and to compare the relative strength of each intergroup emotion on our criterion variables.

Given the high intercorrelation between the intergroup emotions, we chose not to rely solely on standard multiple regression analysis due to known issues in over- and/or underestimating the relative effect sizes within settings of multicollinearity (e.g., Tonidandel \& LeBreton, 2015). As an alternative we chose relative weights analysis (Johnson, 2000), which remedies multicollinearity issues by creating new sets of predictors, which are orthogonal to the original predictors and provide more accurate estimates of the relative strength of each predictor. Specifically, we tested and compared the relative weight of each intergroup emotion on the TIS as a whole as well as on each of its subcomponents following the approach outlined by Tonidandel and LeBreton (2015). Comparing these weights within the sample yields estimates about which emotion is relatively more important compared to others in explaining our criterion variables. We also included results from the traditional multiple regression analyses to display the direction of the relationships between intergroup emotions and our criterion variables.

Table 3 displays the results from the hierarchical regression and relative weights analyses. Due to length considerations, the results for the hierarchical regression analyses are 
presented in SOM (Tables S10-S11). Importance weights are interpreted as the proportion of each variance's contribution to the criterion value (Tonidandel \& LeBreton, 2015); therefore, 
higher relative weights are associated with a higher portion of a model's $R^{2}$. The rescaled importance weights are the percentage of the importance weights' contribution to a model's $R^{2}$ value. Hence, a higher percentage is interpreted as a higher proportion of the total $R^{2}$ value. We included the beta values for comparison purposes and to assess discrepancies between them and importance weights.

Table 3

Multiple Regression and Relative Importance of Intergroup Emotions on Islamophobia and its Subcomponents in the Aggregated Sample $(N=1466)$.

\begin{tabular}{|c|c|c|c|c|c|c|c|c|c|c|c|c|c|}
\hline \multirow[t]{2}{*}{ Country } & \multirow[t]{2}{*}{ Predictors } & \multicolumn{3}{|c|}{ Tripartite Islamophobia Scale } & \multicolumn{3}{|c|}{ Anti-Islam Sentiment } & \multicolumn{3}{|c|}{ Anti-Muslim Prejudice } & \multicolumn{3}{|c|}{ Conspiracy Beliefs } \\
\hline & & $\bar{\beta}$ & $I W$ & $R I W(\%)$ & $\bar{\beta}$ & $I W$ & $R I W(\%)$ & $\bar{\beta}$ & $I W$ & $R I W(\%)$ & $\bar{\beta}$ & $I W$ & $R I W(\%)$ \\
\hline \multirow{6}{*}{$\begin{array}{l}5 \\
\text { Countries } \\
(\mathrm{N}=1466)\end{array}$} & $\begin{array}{l}\text { Fear Islam \& } \\
\text { Muslims }\end{array}$ & $0.32 * * *$ & $.23^{*}$ & 34.04 & $0.25 * * *$ & $.18^{*}$ & 34.05 & $0.26 * * *$ & $.21^{*}$ & 31.93 & $0.35^{* * *}$ & $.21 *$ & 36.03 \\
\hline & $\begin{array}{l}\text { Anger Islam \& } \\
\text { Muslims }\end{array}$ & $0.46^{* * *}$ & $.25^{*}$ & 36.10 & $0.50 * * *$ & $.20^{*}$ & 37.81 & $0.49 * * *$ & $.24^{*}$ & 37.34 & $0.30 * * *$ & $.20 *$ & 33.41 \\
\hline & $\begin{array}{l}\text { Disgust Islam \& } \\
\text { Muslims }\end{array}$ & $0.10^{* *}$ & $.20^{*}$ & 29.86 & -0.01 & $.14^{*}$ & 28.13 & $0.10^{* *}$ & $.20^{*}$ & 30.73 & $0.18^{* * *}$ & $.18^{*}$ & 30.56 \\
\hline & $R^{2}$ & .69 & & & .52 & & & .65 & & & .60 & & \\
\hline & $I W$ & & .69 & & & .52 & & & .65 & & & .60 & \\
\hline & $R I W$ & & & 100 & & & 100 & & & 100 & & & 100 \\
\hline \multirow[t]{3}{*}{$\begin{array}{l}\text { USA } \\
(\mathrm{n}=\mathbf{2 9 5})\end{array}$} & $\begin{array}{l}\text { Fear Islam \& } \\
\text { Muslims }\end{array}$ & $0.30 * * *$ & $.24^{*}$ & 33.39 & $0.29 * * *$ & $.19 *$ & 33.93 & $0.21 * * *$ & $.20^{*}$ & 30.84 & $0.35^{* * *}$ & $.22 *$ & 35.37 \\
\hline & $\begin{array}{l}\text { Anger Islam \& } \\
\text { Muslims }\end{array}$ & $0.60 * * *$ & $.26^{*}$ & 36.90 & $0.63 * * *$ & $.22 *$ & 37.87 & $0.56 * * *$ & $.25^{*}$ & 37.53 & $0.48^{* * *}$ & $.22 *$ & 35.32 \\
\hline & Disgust Islam \& & -0.03 & $.21^{*}$ & 29.71 & -0.15 & $.16^{*}$ & 28.19 & 0.07 & $.21^{*}$ & 31.63 & 0.01 & $.18^{*}$ & 29.31 \\
\hline
\end{tabular}




\section{NATURE OF ISLAMOPHOBIA}

Muslims $\begin{array}{ll}R^{2} & .71\end{array}$

RIW

100

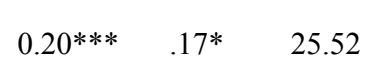

.56

$I W$

$R I W$

Poland Fear Islam \&

( $\mathbf{n}=\mathbf{2 9 7}) \quad$ Muslims

Anger Islam \& Muslims

.67

.56

100

100

.65

.42

100

100

Disgust Islam \& Muslims

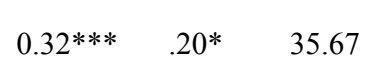

.46

100

.34

100

100

100

France Fear Islam \&

(n= 289) Muslims

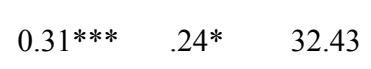




\section{NATURE OF ISLAMOPHOBIA}

Muslims

$R^{2}$

IW

$R I W$

India

(n=292)

\section{Fear Islam \&}

Muslims

Anger Islam \&

Muslims

Disgust Islam \&

Muslims

$R^{2}$

$I W$

IW
.74

.74

100
.51

$\begin{array}{ccc}0.20 * * * & .21 * & 30.52 \\ 0.61 * * * & .25 * & 36.93 \\ 0.04 & .22 * & 32.55\end{array}$

.69
20

.72

.72

100
31.37

$\begin{array}{lll}0.21 * & .17 * & 31.37 \\ 0.64 * * & 20 * \quad 37.45\end{array}$

0.08

.18

27.72

$0.55^{* * *}$

.24

37.62

$0.18 \quad .22 \quad 34.66$

.64

.64

100
.54

100
.64

.64

100

Notes. IW, Importance Weight; RIW, Rescaled Importance Weight. Importance weights are relative weights which sum to the R2 of the full model. Rescaled importance weights are calculated by dividing the importance weight by the R2 of the model.

$* p<.05 ; * * p<.01 ; * * * p<.001$.

In line with our expectations, all three emotions showed unique and significant contributions in explaining our criterion variables (see Table 3 and Tables S10-S11 in the SOM). More specifically, intergroup anger was predictive of Islamophobia, above and beyond fear, in the overall sample as well as in the individual country analyses in terms of explained variance. Intergroup disgust was predictive of Islamophobia in the overall sample and for Germany and France in the country-level analyses. For the USA, Poland, and India, disgust was not predictive of Islamophobia over and above fear and anger. Regarding the subcomponents, again, anger was 
predictive of each subcomponent of our scale across all five countries. Disgust was predictive of some subcomponents in Germany, India, France but not in the USA or Poland (see Table 3).

Taken at face value, the relative weight analyses indicate that anger showed slightly larger and more consistent relative importance weights and explained larger proportions of variance for the TIS as a whole $(I W=0.25, p<0.05 ; R I W=36 \%)$, for antiIslam sentiment $(I W=0.20, p<0.05 ; R I W=37 \%)$, and anti-Muslim prejudice $(I W=0.24 p<0.05 ; R I W=37 \%)$, compared to fear and disgust. On the other hand, fear showed larger relative importance weight and explained larger proportions of variance in regard to conspiracy beliefs $(I W=0.21, p<0.05 ; R I W=36 \%)$.

Next, we tested whether the relative importance weights between the three emotions were significantly different from each other (see Table 4).

Table 4

Comparing Relative Importance Weights of Intergroup Emotions in Predicting Islamophobia and its Subcomponents Across All Samples.

\begin{tabular}{|c|c|c|c|c|c|c|c|c|c|}
\hline \multirow[t]{2}{*}{ Country } & \multirow{2}{*}{$\begin{array}{l}\text { Reference Predictor Emotion } \\
\text { (Intergroup Fear) }\end{array}$} & \multicolumn{2}{|c|}{ Tripartite Islamophobia Scale } & \multicolumn{2}{|c|}{ Anti-Islam Sentiment } & \multicolumn{2}{|c|}{ Anti-Muslim Prejudice } & \multicolumn{2}{|c|}{ Conspiracy Beliefs } \\
\hline & & $\overline{\text { LLCI }}$ & ULCI & LLCI & ULCI & LLCI & ULCI & LLCI & ULCI \\
\hline 5 Countries & Anger Islam \& Muslims & -0.014 & 0.041 & -0.007 & 0.045 & 0.006 & 0.063 & -0.046 & 0.013 \\
\hline$(N=1466)$ & Disgust Islam \& Muslims & -0.055 & -0.002 & -0.055 & -0.007 & -0.036 & 0.020 & -0.063 & -0.003 \\
\hline USA $(n=295)$ & Anger Islam \& Muslims & -0.039 & 0.079 & -0.039 & 0.081 & -0.006 & 0.096 & -0.059 & 0.058 \\
\hline
\end{tabular}




\begin{tabular}{|c|c|c|c|c|c|c|c|c|c|}
\hline & Disgust Islam \& Muslims & -0.083 & 0.011 & -0.083 & 0.012 & -0.043 & 0.053 & -0.093 & 0.017 \\
\hline \multirow[t]{2}{*}{ Germany $(n=293)$} & Anger Islam \& Muslims & 0.022 & 0.140 & 0.032 & 0.133 & 0.048 & 0.171 & -0.064 & 0.072 \\
\hline & Disgust Islam \& Muslims & 0.014 & 0.146 & 0.015 & 0.137 & 0.034 & 0.171 & -0.067 & 0.083 \\
\hline \multirow[t]{2}{*}{ Poland $(n=297)$} & Anger Islam \& Muslims & -0.064 & 0.092 & -0.058 & 0.085 & -0.053 & 0.103 & -0.080 & 0.075 \\
\hline & Disgust Islam \& Muslims & -0.124 & 0.019 & -0.104 & 0.023 & -0.130 & 0.013 & -0.103 & 0.049 \\
\hline \multirow[t]{2}{*}{ France $(n=289)$} & Anger Islam \& Muslims & -0.032 & 0.088 & -0.046 & 0.068 & -0.024 & 0.103 & -0.062 & 0.065 \\
\hline & Disgust Islam \& Muslims & -0.053 & 0.082 & -0.087 & 0.023 & -0.011 & 0.126 & -0.063 & 0.081 \\
\hline \multirow[t]{2}{*}{ India $(n=292)$} & Anger Islam \& Muslims & -0.008 & 0.097 & -0.024 & 0.084 & 0.016 & 0.116 & -0.034 & 0.071 \\
\hline & Disgust Islam \& Muslims & -0.032 & 0.061 & -0.049 & 0.045 & 0.001 & 0.093 & -0.051 & 0.042 \\
\hline
\end{tabular}

Notes. The reference intergroup emotion fear is compared to anger and disgust. If zero is not included in the confidence intervals, weights are significantly different from one another. Significant differences are displayed in bold.

Fear and anger did not show significant differences in their relative weights in explaining TIS, 95\% CI [-.014, .041], anti-Islam sentiment, 95\% CI [-.007, .045], or conspiracy beliefs, 95\% CI [-.046, .013]. However, for anti-Muslim prejudices, the 95\% CI $[.006, .063]$ did not include zero, and thus the results indicate that anger $(I W=0.24 p<0.05, R I W=37 \%)$ had a relatively larger weight size compared to fear $(I W=0.21 p<0.05, R I W=31 \%)$. In the country-level analyses, anger and disgust did now show significant differences in the USA, Poland, or France. However, both anger and disgust were stronger predictors, compared to fear, for the TIS, anti-Islam sentiment, and anti-Muslim prejudice, in Germany. Moreover, both anger and disgust were also significantly 
stronger predictors of anti-Muslim prejudice in India. Table 5 shows the comparison of relative importance weights with disgust as reference predictor.

Table 5

Comparing Relative Importance Weights of Intergroup Emotions in Predicting Islamophobia and its Subcomponents Across All Samples.

\begin{tabular}{|c|c|c|c|c|c|c|c|c|c|}
\hline \multirow[t]{2}{*}{ Country } & \multirow{2}{*}{$\begin{array}{l}\text { Reference Predictor Emotion } \\
\text { (Intergroup Disgust) }\end{array}$} & \multicolumn{2}{|c|}{ Tripartite Islamophobia Scale } & \multicolumn{2}{|c|}{ Anti-Islam Sentiment } & \multicolumn{2}{|c|}{ Anti-Muslim Prejudice } & \multicolumn{2}{|c|}{ Conspiracy Beliefs } \\
\hline & & LLCI & ULCI & LLCI & ULCI & LLCI & ULCI & LLCI & $\overline{\text { ULCI }}$ \\
\hline \multirow[t]{2}{*}{5 Countries $(\mathrm{N}=1466)$} & Fear Islam \& Muslims & 0.001 & 0.055 & 0.006 & 0.055 & -0.020 & 0.036 & 0.003 & 0.062 \\
\hline & Anger Islam \& Muslims & 0.027 & 0.059 & 0.035 & 0.066 & 0.026 & 0.059 & 0.000 & 0.034 \\
\hline \multirow[t]{2}{*}{ USA $(n=295)$} & Fear Islam \& Muslims & -0.023 & 0.077 & -0.011 & 0.085 & -0.055 & 0.041 & -0.014 & 0.093 \\
\hline & Anger Islam \& Muslims & 0.018 & 0.009 & 0.023 & 0.098 & 0.010 & 0.078 & 0.005 & 0.076 \\
\hline \multirow[t]{2}{*}{ Germany $(n=293)$} & Fear Islam \& Muslims & -0.145 & -0.014 & -0.135 & -0.016 & -0.171 & -0.033 & -0.085 & 0.064 \\
\hline & Anger Islam \& Muslims & -0.047 & 0.055 & -0.040 & 0.054 & -0.041 & 0.058 & -0.053 & 0.048 \\
\hline \multirow[t]{2}{*}{ Poland $(n=297)$} & Fear Islam \& Muslims & -0.021 & 0.124 & -0.019 & 0.107 & -0.014 & 0.130 & -0.047 & 0.102 \\
\hline & Anger Islam \& Muslims & 0.029 & 0.108 & 0.014 & 0.091 & 0.048 & 0.128 & -0.021 & 0.065 \\
\hline \multirow[t]{2}{*}{ France $(n=289)$} & Fear Islam \& Muslims & -0.081 & 0.054 & -0.023 & 0.087 & -0.124 & 0.010 & -0.080 & 0.063 \\
\hline & Anger Islam \& Muslims & -0.021 & 0.040 & 0.011 & 0.074 & -0.054 & 0.023 & -0.048 & 0.031 \\
\hline \multirow[t]{2}{*}{ India $(n=292)$} & Fear Islam \& Muslims & -0.061 & 0.033 & -0.047 & 0.049 & -0.093 & -0.001 & -0.041 & 0.053 \\
\hline & Anger Islam \& Muslims & 0.002 & 0.073 & 0.008 & 0.070 & -0.011 & 0.062 & -0.002 & 0.059 \\
\hline
\end{tabular}




\section{NATURE OF ISLAMOPHOBIA}

Notes. The reference intergroup emotion disgust is compared to anger and fear. If zero is not included in the confidence intervals, weights are significantly different from one another. Significant differences are displayed in bold.

In the overall aggregated sample, both fear and anger showed significantly larger associations compared to disgust, except for anti-

Muslim prejudice (see Table 5). Regarding the individual country-analyses, anger was a significantly stronger predictor, compared to disgust for the USA and Poland, while fear and disgust did not differ for these countries. Disgust was also a stronger predictor compared to fear in Germany (except for conspiracy beliefs). Disgust was also relatively stronger compared to fear in predicting antiMuslim prejudice in India. 


\section{Study 1 Discussion}

Study 1 lends support for our hypothesis that Islamophobia is best explained as a threefactor model, consisting of anti-Muslim prejudice, anti-Islam sentiment, and Islamophobic conspiracy beliefs. The Tripartite Islamophobia Scale (TIS) also showed scalar invariance in the overall sample. Hence, the TIS seems appropriate for cross-cultural analysis, including the comparison of mean values. As for the second aim of exploring emotional associations with the TIS, the results were partially in line with our expectations that anger and disgust would be predictive of Islamophobia, above and beyond fear. In the aggregated sample analyses, fear, anger, and disgust were all uniquely associated with Islamophobia as a whole as well as its subcomponents. However, anger and fear did not differ in their relative weight in explaining Islamophobia as a whole. Regarding the analyses of the individual subcomponents, anger was significantly more predictive than fear of the anti-Muslim prejudice dimensions. Moreover, disgust was less predictive than fear of all, except the anti-Muslim prejudice dimension. In terms of country-level analyses, we found a more heterogenous picture which we discuss in more detail in the general discussion.

\section{Study 2}

The aim of Study 2 was twofold. First, we investigated the moderating role of two potential individual differences (i.e., ingroup identification and social dominance orientation) on the relationship between intergroup emotions and Islamophobia (e.g., Kossowska et al., 2008; Matthews \& Levin, 2012). Second, we investigated a number of attitudinal and behavioral outcomes expected to differentially relate to each subcomponent of the TIS. To this end, we tested whether our Islamophobia scale would predict negative intergroup outcome variables as criterion variables while controlling for further related variables. Moreover, based on previous 
research on anti-Semitism (e.g., Bilewicz \& Krzeminski, 2010), we hypothesized that prejudices and conspiracy beliefs would be stronger predictors of intergroup attitudes and behaviors focused on the overt domination and subjugation of Muslims (i.e., ethnic persecution) than anti-Islamic sentiment.

\section{Methods}

Participants. Amazon MTurk was used to collect a USA sample $(N=213)$ between March and April of 2019. The sample consisted of 46.9\% women and the average age was 31.70 $(S D=1.17)$. Moreover, $14.6 \%$ had completed high school or less, $22.5 \%$ had completed some college, $37.6 \%$ had completed a bachelor's degree, and $8.5 \%$ had partially completed or completed a graduate or professional degree. Detailed descriptive statistics for the sample are provided in the SOM (see Table S2).

Instruments. Tripartite Islamophobia Scale (TIS). The TIS developed in Study 1 was administered (anti-Islam sentiment, $\alpha=.91$; anti-Muslim prejudice, $\alpha=.92$; anti-Muslim conspiracy beliefs, $\alpha=.97$; TIS aggregated scale, $\alpha=.96)$ together with the same intergroup emotions scales (fear of Islam and Muslims, $\alpha=.97$; anger toward Islam and Muslims, $\alpha=.97$; disgust toward Islam and Muslims, $\alpha=.97)$. For the TIS, confirmatory factor analysis replicated measurement structure from Study 1 (see Table S13 in SOM).

Individual difference measures. We administered two additional measures, both scored on a five-point scale ranging from 1 (strongly disagree) to 5 (strongly agree).

Social Dominance Orientation. Social dominance orientation was assessed through use of the 16-item (e.g., "Some groups of people are simply inferior to other groups"; $\alpha=.96$ ) SDO7 scale (Ho et al., 2015).

Ingroup identification. Ingroup identification was measured using five items (e.g.; "I feel 
NATURE OF ISLAMOPHOBIA

strongly connected to other Americans"; $\alpha=.96$ ) adapted from the collective self-esteem scale (Luhtanen \& Crocker, 1992).

Predictive validation measures. To assess the incremental validity of our scale, we administered three additional measures. All predictive measures were scored on a five-point scale ranging from 1 (strongly disagree) to 5 (strongly agree) unless stated otherwise.

Ethnic persecution. Ethnic persecution was measured by an adapted version (Thomsen, Green, \& Sidanius, 2008) of Altemeyer's (1996) posse scale. Six items assess one's willingness to participate in the politically sanctioned persecution of Muslims (e.g., "I would participate in attacks on Muslim headquarters if supervised by the proper authorities"; $\alpha=.93$ ).

Anti-Muslim policy support. Support for anti-Muslim policies was assessed by nine items from Kteily, Hodson, and Bruneau (2016; e.g., "We need to stop accepting Muslim refugees into this country, period"; $\alpha=.97)$.

Dehumanization. Dehumanization of outgroup members (i.e., Muslims) was assessed with the Ascent of Man scale (Kteily et al., 2015) in which participants rated the average 'evolvedness' of Muslims from 0-100 (full humanity). We used a reverse score for analysis, with higher values indicating more dehumanization.

Analysis of data. First, we tested whether social dominance orientation and/or ingroup identification moderate the relationship between the intergroup emotions and Islamophobia. Next, to test for the predictive validity of the TIS, we used hierarchical regression analysis by stepwise regressing three criterion variables (e.g., ethnic persecutions) on the three subcomponents of TIS and our individual differences measures. 
NATURE OF ISLAMOPHOBIA

\section{Results}

Table 6 shows the mean scores, standard deviations, and inter-correlations among the criterion variables and the Islamophobia subscales. All the measures showed significant intercorrelations in the expected direction. Additional results are provided in the SOM (Table S12), investigating each intergroup emotion separately for Islam and Muslims.

Table 6

Means, Standard Deviations, Scales, and Intercorrelations Between Variables $(N=213$, USA:

Sample 6).

$\begin{array}{lllllllll}M(S D) & 1 & 2 & 3 & 4 & 5 & 6 & 7 & 8\end{array}$

1. Social dominance orientation $2.010 .97 \quad-$

2. Ingroup identification $\quad 3.731 .07 .26^{* *}$

3. Fear of Islam \& Muslims $\quad 2.171 .29 .44 * * .32 * *$

4. Anger Islam \& Muslims $\quad 2.121 .23 .50 * * .27 * * .83 * *$

5. Disgust Islam \& Muslims $\quad 2.061 .26 .51 * * .25 * * .80 * * .95 * *$

6. Anti-Islam Sentiment $\quad 2.500 .96 .36^{* *} .34 * * .64 * .77 * * .73 * *$

7. Anti-Muslim Prejudice $\quad 2.080 .97 .52 * * .37 * * .73 * * .79 * * .78 * * .79 * *$

8. Conspiracy Beliefs $\quad 2.381 .36 .47 * * .34 * * .71 * * .80 * * .78 * * .81 * * .87 * *$

9. Tripartite Islamophobia Scale $2.351 .04 .48 * * .37 * * .75^{* *} .83 * * .80 * * .92 * * .94 * * .94 * *$ ** $p<.01$.

Moderation analysis. To test whether ingroup identification and/or SDO would moderate the relationship between the three intergroup emotions and Islamophobia we ran a hierarchical regression analysis. In the first step, we entered both individual difference variables 
NATURE OF ISLAMOPHOBIA

ingroup identification and SDO along with the intergroup emotions. In the second step, we additionally entered the interaction terms between the moderators (centered) and the intergroup emotions (centered). Table 7 shows a summary of the hierarchical regression analysis for Islamophobia.

Table 7

Regression Analyses Predicting Islamophobia.

\begin{tabular}{|c|c|c|c|c|c|}
\hline \multirow[t]{2}{*}{ 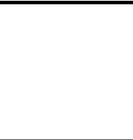 } & \multirow[t]{2}{*}{ Model } & \multicolumn{4}{|c|}{ Tripartite Islamophobia Scale } \\
\hline & & $B$ & $S E(H C 4)$ & $t$ & $p$ \\
\hline \multirow[t]{5}{*}{ Step 1} & Ingroup identification & 0.15 & .05 & 2.72 & .007 \\
\hline & Social dominance orientation & 0.08 & .07 & 1.22 & .225 \\
\hline & Intergroup fear & 0.11 & .08 & 1.44 & .152 \\
\hline & Intergroup anger & 0.51 & .15 & 3.32 & .001 \\
\hline & Intergroup disgust & 0.21 & .14 & 1.45 & .148 \\
\hline \multirow[t]{11}{*}{ Step 2} & Ingroup identification (ID) & 0.14 & .06 & 2.41 & .017 \\
\hline & Social dominance orientation (SDO) & 0.12 & .07 & 1.76 & .079 \\
\hline & Intergroup fear & 0.08 & .08 & 0.97 & .334 \\
\hline & Intergroup anger & 0.41 & .16 & 2.55 & .011 \\
\hline & Intergroup disgust & 0.34 & .15 & 2.18 & .030 \\
\hline & ID*Fear & 0.26 & .09 & 2.88 & .004 \\
\hline & ID*Anger & -0.16 & .14 & -1.15 & .250 \\
\hline & ID*Disgust & -0.08 & .13 & -0.58 & .565 \\
\hline & SDO*Fear & -0.19 & .07 & 2.61 & .009 \\
\hline & SDO*Anger & 0.39 & .19 & 2.00 & .046 \\
\hline & SDO*Disgust & -0.24 & .17 & -1.39 & .166 \\
\hline
\end{tabular}

Notes. Continuous variables (ingroup identification, social dominance orientation, and intergroup emotions) are centered. Significant effects are displayed in bold. 
In the first step of the analysis, $F(5,207)=81.1, p<.001, R^{2}=.66$, only ingroup identification and intergroup anger showed significant effects on Islamophobia. Entering the interaction terms in the second step of the analysis, $F(11,201)=39.11, p<.001, R^{2}=.68$, increased the explained variance slightly by $2 \%$. In the second step, intergroup disgust also showed a significant positive effect. ${ }^{1}$ Regarding the moderation analyses, in line with our expectations, ingroup identification and fear showed a significant interaction, such that higher fear was associated with increased Islamophobia among those with higher ingroup identification (see Figure 2).
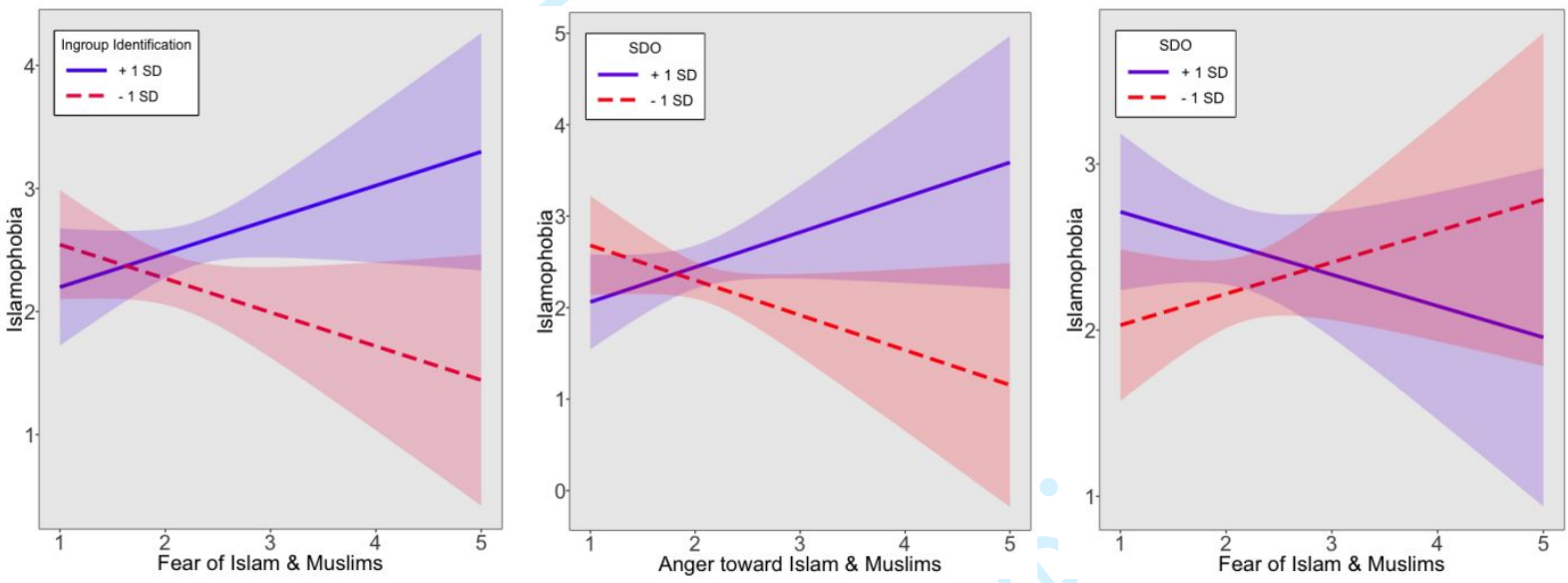

Figure 2. Simple slopes for interactions between intergroup emotions and ingroup identification and SDO. Ribbons present 95\% confidence intervals.

Moreover, in line with our hypothesis, anger and SDO showed a significant interaction such that higher anger was associated with increased Islamophobia for individuals high in SDO. Unexpectedly, SDO also showed a significant interaction with fear, such that higher fear was associated with significantly higher Islamophobia for low SDO individuals. No interaction between disgust and SDO or ingroup identification was indicated. 
NATURE OF ISLAMOPHOBIA

Predictive validity. Lastly, we regressed three negative intergroup outcome variables (dehumanization, support for anti-Muslim policies, and ethnic persecutions) on demographic indicators, ingroup identification, SDO, and our TIS subscales in hierarchical multiple regression analyses. This enabled us to test the incremental validity of our scale by controlling for predictors expected to be related to the criterion variables. In the first step, we entered demographic variables (age, gender, education, and political orientation), ingroup identification and SDO. In the second step, we entered all subcomponents of our Islamophobia scale (antiMuslim prejudice, anti-Islam sentiment, and conspiracy beliefs) into the model (see Table 8).

Table 8

Regression Analysis with the Three Subcomponents of the Tripartite Islamophobia Scale and Criterion Variables $(N=213$, Sample 6).

Islamophobia criteria

Dehumanization Anti-Muslim Policy Ethnic Persecution

$\begin{array}{llllllllll}\beta & S E(H C 4) & p & \beta & S E(H C 4) & p & \beta & S E(H C 4) & p\end{array}$

\begin{tabular}{|c|c|c|c|c|c|c|c|c|c|}
\hline \multicolumn{10}{|l|}{$\overline{\text { Step } 1}$} \\
\hline Age & .19 & 0.06 & .752 & -.18 & 0.03 & .581 & -.05 & 0.04 & .198 \\
\hline Gender & .13 & 0.14 & .348 & .15 & 0.08 & .045 & -.18 & 0.09 & .048 \\
\hline Education & .00 & 0.05 & .972 & -.04 & 0.03 & .187 & -.04 & 0.03 & .231 \\
\hline Political orientation & .05 & 0.06 & .412 & -.00 & 0.03 & .957 & -.03 & 0.04 & .519 \\
\hline Ingroup identification & -.07 & 0.07 & .338 & .04 & 0.04 & .300 & .00 & 0.04 & .962 \\
\hline SDO & .18 & 0.09 & .049 & -.18 & 0.03 & $<.001$ & -.05 & 0.04 & $<.001$ \\
\hline \multicolumn{10}{|l|}{ Step 2} \\
\hline Anti-Islam Sentiment & .03 & 0.13 & .795 & -.13 & 0.07 & .075 & -.17 & 0.08 & .037 \\
\hline Anti-Muslim Prejudice & .12 & 0.16 & .452 & .73 & 0.09 & $<.001$ & .52 & 0.10 & $<.001$ \\
\hline Conspiracy Beliefs & .39 & 0.12 & $<.001$ & .37 & 0.06 & $<.001$ & .26 & 0.07 & $<.001$ \\
\hline Adjusted $\mathbf{R}^{2}$ & \multicolumn{4}{|c|}{.36} & \multicolumn{2}{|c|}{.83} & \multicolumn{3}{|c|}{.67} \\
\hline Change in adjusted $R^{2}$ & \multicolumn{4}{|c|}{.17} & \multicolumn{2}{|c|}{.37} & \multicolumn{3}{|c|}{.23} \\
\hline
\end{tabular}


$\begin{array}{llll}\text { Standard error of estimate } & .97 & .53 & .62\end{array}$

Significant $\boldsymbol{F}$ change $\quad p<.001 \quad p<.001 \quad p<.001$

Notes. Values reflect $\beta$ coefficients for the full model. Age: 1 (lower) - 5 (higher); Gender: 1 (Male) - 2

(Female); Education: 1 (low) - 12 (high); Political Orientation: 1 (left) - 5 (right). All constructs were entered stepwise in a two-step hierarchical regression model. Significant effects are displayed in bold.

Consistent with our expectation, anti-Muslim prejudice and the conspiracy belief subcomponents were significant and unique predictors, controlling for all the remaining measures, and explained an additional $17 \%$ to $37 \%$ of the total variance, over and above the well-established measures in the model (see Table 8). ${ }^{2}$ In line with our expectation, anti-Muslim prejudice and conspiracy beliefs outperformed anti-Islam sentiment in predictive power. Conspiracy beliefs were, moreover, significantly associated with dehumanization.

\section{Study 2 Discussion}

Study 2 tested two individual difference variables explaining distinct emotional reactions to Islam and Muslims. Furthermore, we analyzed the incremental validity of the TIS. As hypothesized, especially for individuals high in SDO, anger was associated with higher Islamophobia. This is in line with previous research indicating a close relationship between SDO and intergroup anger (e.g., Matthews \& Levin, 2012). Moreover, as expected, social identification moderated the effects of fear on Islamophobia. Unexpectedly, the results indicated that SDO also interacted with fear, such that higher fear and low SDO interacted in predicting increased Islamophobia. However, no interaction with disgust was shown. This suggests that other potential moderating factors might be at play that need further exploration to explain the disgust-Islamophobia nexus. We will discuss these finding in more detail in the general discussion. 
Regarding the incremental validity of our scale, we hypothesized and found support that, compared to anti-Islamic sentiment, both anti-Muslim prejudice and conspiracy beliefs had larger effects on behavioral inclinations that promote the active and forceful oppression of Muslims and Islamic organizations (e.g., support for anti-Muslim policies). This prediction was partly based on research on anti-Semitism, which showed that above and beyond anti-Semitic prejudices, anti-Semitic conspiracy beliefs were most significantly predictive of negative intergroup outcome measures (Bilewicz et al., 2013).

\section{General Discussion}

Since the introduction of the term about 30 years ago, several conceptualizations and models of Islamophobia have been proposed (Bleich, 2011; Klug, 2012). Yet, many theoretical and methodological issues have persisted including a lack of knowledge about Islamophobia's 1) components, 2) cross-cultural validity, 3) emotional underpinnings, 4) relation to individual differences, and 5) societal consequences. In this paper, we aimed to address each of these issues. Across several cultures, we reliably distinguished between three different types of attitudes and beliefs about Islam and Muslims, using the Tripartite Islamophobia Scale (TIS). Second, across cultural contexts, we systematically showed that both anger and - to a lesser degree - disgust predict Islamophobia in addition to fear. Third, we demonstrate that individual differences in the emotional reactions of anger and fear can be explained as a function of social dominance orientation and ingroup identification. Finally, we analyze the scale's predictive validity and demonstrate its relevance in explaining important societal outcomes (e.g., blatant dehumanization, anti-Muslim policy support). 


\section{A New and Cross-Culturally Valid Islamophobia Measure}

One of the more persistent issues regarding research on Islamophobia was the lack of a cross-culturally validated instrument to measure the phenomena across time, groups, and geographical regions. Therefore, we designed and tested our Islamophobia measure in five different cultural contexts. The results show that our TIS instrument indicates full scalar invariance. This suggests that the scale assesses the same underlying constructs in each setting and, hence, may be used to make valid comparisons, including among different mean levels, of Islamophobia across cultures.

Moreover, we contribute to current discussions of the comparability of Islamophobia with anti-Semitism and other prejudices, a topic which has triggered heated debates in the academic and public discourse, including questioning whether or not these phenomena are comparable to each other (e.g., Küntzl, 2008; Uenal, 2016c). Our results indicate that - comparable to modern anti-Semitism - Islamophobia manifest itself in different ways: negative sentiments against the Islamic religion, prejudice against Muslim individuals, and conspiracy beliefs about Muslims as collective agents with malicious and deceptive intentions. Our measure, thus, offers a conceptually sound way to compare Islamophobia with other forms of prejudices and conspiracy beliefs.

\section{Conspiracy Beliefs as Component of Islamophobia}

Our research advances theoretical discussions on Islamophobia by adding to a neglected, yet crucial, aspect of the concept: conspiracy beliefs. The results of this paper indicate that Islamophobic conspiracy beliefs were a statistically unique factor in five different cultural settings. We also found that the subcomponents disassociated in terms of the downstream intergroup outcomes they best predicted (i.e., ethnic persecution, dehumanization, anti-Muslim 
policy support). Similar to findings on anti-Semitism (Bilewicz \& Krzeminski, 2010; Bilewicz et al., 2013), on which we partly based our hypothesis, we found that beyond anti-Islam sentiment alone, anti-Muslim prejudice and especially adherence to conspiracy beliefs were most predictive of these outcomes. Both of these subcomponents explained our three criterion variables over and above anti-Islamic sentiment. Crucially, our scale also showed good incremental validity and predicted the criterion variables, even when controlling for demographic variables, ingroup identification, and social dominance orientation. Moreover, we found that the conspiracy beliefs sub-component showed robust association with fear across the samples and, compared to disgust, slightly stronger associations with fear in the overall sample analyses. This finding aligns with previous experimental research showing that belief in conspiracy theories is associated with anxiety, uncertainty, and a perceived lack of control (e.g., van Prooijen \& Douglas, 2018; Whitson \& Galinsky, 2008).

\section{Emotional Underpinnings of Islamophobia Across Cultures}

Taking a socio-functional and threat-based approach to prejudice (e.g., Neuberg \& Schaller, 2016), we hypothesized that anger and disgust would be predictive of Islamophobia, above and beyond fear. Indeed, we found that, controlling for intergroup fear, anger and disgust were unique and significant predictors of Islamophobia in the aggregated sample, explaining Islamophobia taken as a whole as well as its subcomponents, albeit to varying degrees. Nevertheless, applying a more stringent test to compare the relative strength of each emotion showed that anger and fear did not significantly differ in their relative predictive strength for the aggregated Islamophobia scale. However, anger was a significantly stronger predictor for the anti-Muslim prejudice component compared to both fear and disgust. Also, both anger and fear were significantly stronger predictors, compared to disgust, of the aggregated scale as well as 
two of its subcomponents. Thus, in addition to fear, considering both anger and disgust as integral parts of Islamophobia seems warranted.

In the country level analyses, the results were more heterogenous. To start with, fear did not differ in relative strength from anger and disgust for the USA, Poland, and France. However, for Germany, we found that both anger and disgust showed significantly stronger associations with Islamophobia compared to fear. Anger, on the other hand, was significantly stronger compared to disgust for the USA, Poland and, partially, also for both France (anti-Islam sentiment) and India (TIS and anti-Islam sentiment).

Overall, this paper advances research on the emotional underpinning of Islamophobia by providing cross-cultural evidence for the relevance of the anger- and disgust-bases of Islamophobia. While our results indicate that fear does play a significant role in explaining Islamophobia, as suggested by the most prominent definitions and conceptualizations of current Islamophobia, our results ascribe anger an equally large role for explaining Islamophobia. Disgust, though significantly smaller in effect size, also played a significant role in predicting Islamophobia in the aggregated sample, and thus warrants more attention. Our findings on the country-level of analysis paint a more heterogenous picture and point to context-dependent emotional underpinnings of Islamophobia. While it exceeds the aim and scope of this paper to explain the country-level variations that were not based on representative samples, they nevertheless raise intriguing questions as to how to explain such cross-cultural differences. For instance, in Germany, France, and also partially in India where anger and disgust were significant predictors of Islamophobia and most of its individual subcomponents, there are much larger Muslim populations (6.1\% in Germany, $8.8 \%$ in France, and 15\% in India; PEW, 2017) compared to the USA and Poland (less than 1\% of the overall population; PEW, 2017). Given 
this, greater anger and disgust reactions in these samples might be a function of perceptions of increased socio-economic competition as well as perceptions of decreased collective support for the non-Muslim ingroup relative to population strength. Another interesting pattern which emerged is that anti-Muslim prejudice was more strongly associated with anger compared to fear, and in some countries, also stronger compared to disgust. Future research should further investigate these patterns and contextual differences.

\section{Fear \& Anger: Moderation by Social Dominance Orientation and Ingroup Identification}

This article also advances previous research by examining how differential emotional underpinnings of Islamophobia seem to partially serve as a function of psychological mechanisms (i.e., SDO and ingroup identification). Partially in line with our hypotheses, we found that individuals who scored higher on SDO showed more Islamophobia in conjunction with anger, but not disgust or fear. This is in accordance with previous research analyzing the associations of SDO and emotions in predicting negative intergroup outcomes, which points to anger as the primary affective component of an SDO mindset (e.g., Matthews \& Levin, 2012). SDO has been consistently shown to be a robust predictor of negative outgroup attitudes and behavior signaling aggression towards low-status groups (Sidanius et al., 2017). An interesting, yet unexpected, finding of our study is the significant interaction between fear and SDO negatively predicting Islamophobia. More specifically, our results show that the effect of fear on Islamophobia seems to be buffered for high SDO individuals, while for low SDO individuals, fear leads to more Islamophobia. Low SDO has been previously associated with less negative intergroup bias. Individuals low in SDO are construed as more egalitarian and less dominant and as such, less prejudiced. However, our results indicate, if intergroup fear is present, low SDO can be associated with higher prejudice. 
In contrast to SDO, we hypothesized that fear and disgust, but not anger, would interact with higher ingroup identification in predicting Islamophobia. Indeed, for individuals highly identified with their ingroup, we found that fear amplifies Islamophobic attitudes and beliefs. We interpret this finding in light of research which shows that ingroup identification is more indicative of ingroup love rather than outgroup derogation per se (Brewer, 1999; Levin \& Sidanius, 1999). Individuals highly attached to their ingroup might adopt derogatory outgroup attitudes as a means of signaling their ingroup preference and thereby re-asserting their distinctiveness and facilitating ingroup solidarity. Nevertheless, previous research has also shown that the association between ingroup identification and negative outgroup affect varies in tandem with other factors, such as perceived collective support (e.g., Mackie \& Smith, 2015). Future studies might consider assessing both ingroup identification and perceived collective support as potential moderators to further explore the fear-Islamophobia nexus. Finally, we could not find an interaction with either of our moderators and disgust. Previous research has shown that right-wing authoritarianism (Altemeyer, 1996), an individual difference construct closely related, yet distinct from SDO, might be a better suited moderator between disgust and prejudice (e.g., Sibley \& Duckitt, 2008).

Overall, our findings add to previous efforts of assessing ideological attitudes and social identification together with intergroup emotions in predicting specific intergroup outcomes (e.g., Kossowska et al., 2008; Matthews \& Levin, 2012). In addition to corroborating previous results, our findings contribute to research by showing that low SDO can also be associated with higher prejudice, given the presence of intergroup fear. This is novel in light of previous research which has consistently found low SDO to be associated with less prejudice across different intergroup contexts (Sidanius et al., 2017). Our results indicate that an egalitarian and non-dominant 
NATURE OF ISLAMOPHOBIA

worldview, as indicated by low levels of SDO, might not be sufficient to buffer the effects of fear on prejudice, at least not in the case of Islamophobia. Future studies could further explore this relationship.

\section{Limits on Generality}

While we believe that the cross-cultural approach taken in this study is a strength, the results should also be interpreted in light of some limitations. For instance, some sociodemographics varied between the countries (see Table S2 SOM). Moreover, although MTurk samples (and, presumably, PROLIFIC samples as well), are more representative than traditional social psychological samples (Paolacci \& Chandler, 2014), these samples are not fully representative. In addition, concepts like Islamophobia are not static entities and develop over time. Thus, future research might re-evaluate item selections depending on time, geography, and socio-political contexts, and potentially add further items to the scale. Indeed, the cross-cultural approach taken in the present research does not claim that the culturally most relevant or even most valid aspects of Islamophobia were assessed in each study. Although the item selection was based on extensive preliminary research and literature and was discussed with researchers from most of the countries in which data were collected, future research may profitably validate the content of the scales by, for instance, using qualitative methods as well. Beside others, this may allow a validation of the scale's content against people's evaluations, attitudes and feelings regarding Muslims and their religion from a bottom-up perspective. Furthermore, future studies could consider behavioral validation methods, in addition to self-report validation approaches, to further gauge the psychometric properties of our scale.

Moreover, the three subcomponents of the TIS were strongly correlated. On the one hand, this may indicate the intertwined nature of Islamophobic attitudes and sentiments. On the other 
hand, future refinements of this scale may test whether rephrasing some of the items possibly reduces linguistic overlap between them, which may have led to higher inter-item correlations. Nevertheless, despite these findings, it is important to note that our proposed three-factor solution was confirmed across five culturally different countries supporting the tripartite nature of Islamophobia. Furthermore, criterion validation analyses further corroborated our tripartite view by showing theoretically justifiable, and statistically significant disassociation, of the three subcomponents in regard to their respective emotional antecedents as well as the intergroup outcomes they predict.

\section{Practical Implications and Future Directions}

An interesting area for future research highlighted by the present work concerns Islamophobic conspiracy beliefs. Our results indicate that the phenomenon is common across the analyzed cultural contexts and statistically distinct from the other two subcomponents. Yet, it remains an under-investigated phenomenon. Further research on the emotional bases of Islamophobia (and other prejudices) in different regional contexts could advance knowledge on the proximal, ultimate, and societal factors that may explain cross-country variations. Future studies could also investigate further individual and group differences as potential moderators of the relationship between intergroup emotions and Islamophobia. Specifically, analyzing the role of perceived collective support and threat perceptions in fear-modulation might prove fruitful. We hope that by providing a more rigorous operationalization, as well as enhanced tools of assessment of Islamophobia and its substantive subcomponents, the present research can help facilitate further research concerned with the causes and consequences of Islamophobia. 
NATURE OF ISLAMOPHOBIA

\section{References}

Abalakina-Paap, M., Stephan, W. G., Craig, T., \& Gregory, W. L. (1999). Beliefs in

Conspiracies. Political Psychology, 20(3), 637-647. http://doi.org/10.1111/0162-

$895 X .00160$

Adorno, T. W., Frenkel-Brunswik, E., Levinson, D. J., \& Sanford, R. N. (1950). The Authoritarian Personality. New York, NY: Harper and Row.

Allport, G. W. (1954). The nature of Prejudice. Reading MA: Addison-Wesley.

Altemeyer, B. (1996). The authoritarian specter. Cambridge, MA: Harvard University Press.

Bangstad, S. (2016). Islamophobia: What's in a Name? Journal of Muslims in Europe, 5(2), 145-169. http://doi.org/10.1163/22117954-12341324

Bartlett, J., \& Miller, C. (2010). The power of unreason: conspiracy theories, extremism and counter-terrorism. London: Demos. Retrieved April 13, 2018, from http://westernvoice.net/Power of Unreason.pdf

Bilewicz, M., \& Krzeminski, I. (2010). Anti-Semitism in Poland and Ukraine: The belief in Jewish control as a mechanism of scapegoating. International Journal of Conflict and Violence, 4(2), 234-243.

Bilewicz, M., Winiewski, M., Kofta, M., \& Wójcik, A. (2013). Harmful ideas, The structure and consequences of Anti-Semitic beliefs in Poland. Political Psychology, 34(6), 821-839. http://doi.org/DOI: 10.1111/pops.12024

Bleich, E. (2011). What Is Islamophobia and How Much Is There? Theorizing and Measuring an Emerging Comparative Concept. American Behavioral Scientist, 55(12), 1581-1600. http://doi.org/10.1177/0002764211409387

Brewer, M. B. (1999). The psychology of prejudice: Ingroup love or outgroup hate? Journal of 
Social Issues, 55(3), 429-444. https://doi.org/10.1111/0022-4537.00126

Brown, R. (2010). Prejudice : its social psychology (2nd Ed.). Oxford: Wiley-Blackwell.

Chen, F. F. (2007). Sensitivity of Goodness of Fit Indexes to Lack of Measurement Invariance. Structural Equation Modeling: A Multidisciplinary Journal, 14(3), 464-504. http://doi.org/10.1080/10705510701301834

Choma, B. L., Hodson, G., \& Costello, K. (2012). Intergroup disgust sensitivity as a predictor of islamophobia: The modulating effect of fear. Journal of Experimental Social Psychology, 48(2), 499-506. http://doi.org/10.1016/j.jesp.2011.10.014

Choma, B. L., Haji, R., Hodson, G., \& Hoffarth, M. (2016). Avoiding cultural contamination: Intergroup disgust sensitivity and religious identification as predictors of interfaith threat, faith-based policies, and islamophobia. Personality and Individual Differences, 95, 50-55. http://doi.org/10.1016/j.paid.2016.02.013

Conway, G. (1997). Islamophobia - A challenge for us all. Report of the Runnymede Trust Commission on British Muslims and Islamophobia. London, UK.

Duckitt, J. (2001). A dual-process cognitive-motivational theory of ideology and prejudice. Advances in Experimental Social Psychology, 33, 41-113. https://doi.org/10.1016/s00652601(01)80004-6

Dumont, M., Yzerbyt, V., Wigboldus, D., \& Gordijn, E. H. (2003). Social Categorization and Fear Reactions to the September 11th Terrorist Attacks. Personality and Social Psychology Bulletin, 29(12), 1509-1520. https://doi.org/10.1177/0146167203256923

Elahi, F., \& Khan, O. (2017). Islamophobia. Still a challenge for us all. A 20th-anniversary report. London, UK. Retrieved February 9, 2018, from https://www.runnymedetrust.org/projects-and-publications/equality-and- 
NATURE OF ISLAMOPHOBIA

integration/islamophobia.html

Faul, F., Erdfelder, E., Buchner, A., \& Lang, A.-G. (2009). Statistical power analyses using G*Power 3.1: Tests for correlation and regression analyses. Behavior Research Methods, 41(4), 1149-1160. https://doi.org/10.3758/BRM.41.4.1149

Fekete, L. (2012). The Muslim conspiracy theory and the Oslo massacre. Race \& Class, 53(3), 30-47. http://doi.org/10.1177/0306396811425984

Gallup World. (2013). Islamophobia: understanding anti-Muslim sentiment in the West. Retrieved February 4, 2018, from http://www.gallup.com/poll/157082/islamophobiaunderstanding-anti-muslim-sentiment-west.aspx

Goodwin, M. J., Raines, T., \& Cutts, D. (2017). What Do Europeans Think About Muslim Immigration? London, UK. Retrieved March 3, 2017, from https://www.chathamhouse.org/expert/comment/what-do-europeans-think-about-muslimimmigration

Hafez, F. (2013). Islamophobe Weltverschwörungstheorien [Islamophobic Conspiracy Theories]. Journal Für Psychologie, 21(1), 1-22.

Halliday, F. (1999). "Islamophobia” reconsidered. Ethnic and Racial Studies, 22(5), 892-902. http://doi.org/10.1080/014198799329305

Helbling, M. (2012). Islamophobia in the West: Measuring and Explaining Individual Attitudes. (M. Helbling, Ed.). London: Routledge.

Ho, A. K., Sidanius, J., Kteily, N., Sheehy-Skeffington, J., Pratto, F., Henkel, K. E., ... Stewart, A. L. (2015). The nature of social dominance orientation: Theorizing and measuring preferences for intergroup inequality using the new $\mathrm{SDO}_{7}$ scale. Journal of Personality and Social Psychology, 109(6), 1003-28. http://doi.org/10.1037/pspi0000033 
Horn, J. L., \& Mcardle, J. J. (1992). A practical and theoretical guide to measurement invariance in aging research. Experimental Aging Research, 18(3), 117-144. https://doi.org/10.1080/03610739208253916

Hodson, G., Choma, B. L., Boisvert, J., Hafer, C. L., MacInnis, C. C., \& Costello, K. (2013). The role of intergroup disgust in predicting negative outgroup evaluations. Journal of Experimental Social Psychology, 49(2), 195-205. https://doi.org/10.1016/J.JESP.2012.11.002

Human Rights Watch (2018). “Eradicating Ideological Viruses” China’s Campaign of Repression Against Xinjiang's Muslims. Retrieved May 20, 2019, from https://www.hrw.org/report/2018/09/09/eradicating-ideological-viruses/chinas-campaignrepression-against-xinjiangs

Imhoff, R., \& Recker, J. (2012). Differentiating Islamophobia: Introducing a New Scale to Measure Islamoprejudice and Secular Islam Critique. Political Psychology, 33(6), 811-824. http://doi.org/10.1111/j.1467-9221.2012.00911.x

Johnson, J. W. (2000). A heuristic method for estimating the relative weight of predictor variables in multiple regression. Multivariate Behavioral Research, 35(1), 1-19. https://doi.org/10.1207/S15327906MBR3501_1

Jost, J. T., Glaser, J., Kruglanski, A. W., \& Sulloway, F. J. (2003). Political conservatism as motivated social cognition. Psychological Bulletin, 129(3), 339-375. http://doi.org/10.1037/0033-2909.129.3.339

Jöreskog, K. G. (1971). Simultaneous factor analysis in several populations. Psychometrika, 36(4), 409-426. http://doi.org/10.1007/BF02291366

Ketelaar, T. (2015). Evolutionary Psychology and Emotion: A Brief History. In V. Zeigler-Hill, 
L. L. M. Welling, \& T. K. Shackelford (Eds.), Evolutionary Perspectives on Social Psychology (pp. 51-67). Cham: Springer. http://doi.org/10.1007/978-3-319-12697-5_5

Klug, B. (2012). Islamophobia: A concept comes of age. Ethnicities, 12(5), 665-681. http://doi.org/10.1177/1468796812450363

Kteily, N., Bruneau, E., Waytz, A., \& Cotterill, S. (2015). The ascent of man: Theoretical and empirical evidence for blatant dehumanization. Journal of Personality and Social Psychology, 109(5), 901-931. http://doi.org/10.1037/pspp0000048

Kteily, N., Hodson, G., \& Bruneau, E. (2016). They see us as less than human: Metadehumanization predicts intergroup conflict via reciprocal dehumanization. Journal of Personality and Social Psychology, 110(3), 343-370. http://doi.org/10.1037/pspa0000044

Kunst, J. R., Sam, D. L., \& Ulleberg, P. (2013). Perceived islamophobia: Scale development and validation. International Journal of Intercultural Relations, 37(2), 225-237. https://doi.org/10.1016/j.ijintrel.2012.11.001

Küntzl, M. (2008). "Islamophobia” or “Truthophobia"? Berlin’s anti-Semitism center is going astray. Retrieved October 22, 2014, from http://online.wsj.com/news/articlesSB122869182286886467

Lee, S. A., Reid, C. A., Short, S. D., Gibbons, J. A., Yeh, R., \& Campbell, M. L. (2013). Fear of Muslims: Psychometric evaluation of the Islamophobia Scale. Psychology of Religion and Spirituality, 5(3), 157-171. http://doi.org/10.1037/a0032117

Leibold, J., \& Kühnel, S. (2006). Islamophobie: Differenzierung tut not [Islamophobia: Differentiation is necessary]. In W. Heitmeyer (Ed.), Deutsche Zustände. Folge 4 (pp. 135155). Frankfurt a. Main: Suhrkamp.

Levin, S., \& Sidanius, J. (1999). Social dominance and social identity in the United States and 
Israel: Ingroup favoritism or outgroup derogation? Political Psychology, 20(1), 99-126. https://doi.org/10.1111/0162-895X.00138

Luhtanen, R., \& Crocker, J. (1992). A collective Self-Esteem Scale: Self-Evaluation of One's Social Identity. Personality and Social Psychology Bulletin, 18(3), 302-318. http://doi.org/10.1177/0146167292183006

Kossowska, Małgorzata Bukowskia, M., \& Van Hielb, A. (2008). The impact of submissive versus dominant authoritarianism and negative emotions on prejudice. Personality and Individual Differences, 45, 744-749.

Mackie, D. M., Devos, T., \& Smith, E. R. (2000). Intergroup emotions: Explaining offensive action tendencies in an intergroup context. Journal of Personality and Social Psychology, 79(4), 602-616. http://doi.org/10.1037//0022-3514.79.4.602

Mackie, D. M., \& Smith, E. R. (2015). Intergroup emotions. In APA handbook of personality and social psychology, Volume 2: Group processes. (pp. 263-293). American Psychological Association. https://doi.org/10.1037/14342-010

Matthews, M., \& Levin, S. (2012). Testing a dual process model of prejudice: Assessment of group threat perceptions and emotions. Motivation and Emotion, 36(4), 564-574. https://doi.org/10.1007/s11031-012-9280-y

Miles, R., \& Brown, M. (2003). Racism (2nd editio). London, UK: Routledge.

Moscovici, S. (1987). The Conspiracy Mentality. In C. F. Graumann \& S. Moscovici (Eds.), Changing Conceptions of Conspiracy (pp. 151-169). New York, NY: Springer. http://doi.org/10.1007/978-1-4612-4618-3

Neuberg, S. L., \& Schaller, M. (2016). An evolutionary threat-management approach to prejudices. Current Opinion in Psychology, 7, 1-5. 
NATURE OF ISLAMOPHOBIA

http://doi.org/10.1016/j.copsyc.2015.06.004

Nilsson, I., \& Ekehammar, B. (1987). Person-positivity bias in political perception? European Journal of Social Psychology, 17(2), 247-252. https://doi.org/10.1002/ejsp.2420170210

O’Donnell, S. J. (2018). Islamophobic conspiracism and neoliberal subjectivity: the inassimilable society. Patterns of Prejudice, 52(1), 1-23. http://doi.org/10.1080/0031322X.2017.1414473

Paolacci, G., \& Chandler, J. (2014). Inside the Turk: Understanding Mechanical Turk as a Participant Pool. Current Directions in Psychological Science, 23(3), 184-188. https://doi.org/10.1177/0963721414531598

Park, J. H., Schaller, M., \& Crandall, C. S. (2007). Pathogen-avoidance mechanisms and the stigmatization of obese people. Evolution and Human Behavior, 28(6), 410-414. http://doi.org/10.1016/j.evolhumbehav.2007.05.008

Pew Research Center. (2017). “Europe’s Growing Muslim Population” (Nov. 29, 2017). Retrieved August 19, 2019, from https:/www.pewforum.org/2017/11/29/europes-growingmuslim-population/

PEW. (2017). “Americans Express Increasingly Warm Feelings Toward Religious Groups.” Retrieved February 3, 2018, from http://assets.pewresearch.org/wpcontent/uploads/sites/11/2017/02/15093007/Feeling-thermometer-report-FOR-WEB.pdf Plutchik, R. (1980). Emotion: A psychoevolutionary synthesis. New York, NY, US: Harper \& Row.

Pratto, F., Sidanius, J., Stallworth, L. M., \& Malle, B. F. (1994). Social dominance orientation: A personality variable predicting social and political attitudes. Journal of Personality and Social Psychology, 67(4), 741-763. https://doi.org/10.1037//0022-3514.67.4.741

Riek, B. M., Mania, E. W., \& Gaertner, S. L. (2006). Intergroup Threat and Outgroup Attitudes: 
A Meta-Analytic Review. Personality and Social Psychology Review, 10(4), 336-353. https://doi.org/10.1207/s15327957pspr1004_4

Rosseel, Y. (2012). lavaan: An $R$ Package for Structural Equation Modeling. Journal of Statistical Software, 48(2), 1-36. http://doi.org/10.18637/jss.v048.i02

Schaller, M., \& Park, J. H. (2011). The Behavioral Immune System (and Why It Matters). Current Directions in Psychological Science, 20(2), 99-103. http://doi.org/10.1177/0963721411402596

Schiffer, S., \& Wagner, C. (2011). Anti-Semitism and Islamophobia - new enemies, old patterns. Race \& Class, 52(3), 77-84. http://doi.org/10.1177/0306396810389927

Sears, D. O. (1983). The person-positivity bias. Journal of Personality and Social Psychology, 44(2), 233-250. https://doi.org/10.1037/0022-3514.44.2.233

Sibley, C. G., \& Duckitt, J. (2008). Personality and Prejudice: A Meta-Analysis and Theoretical Review. Personality and Social Psychology Review, 12(3), 248-279. https://doi.org/10.1177/1088868308319226

Sidanius, J., Cotterill, S., Sheehy-Skeffington, J., Kteily, N., \& Carvacho, H. (2017). Social Dominance Theory: Explorations in the Psychology of Oppression. In C. G. Sibley \& F. K. Barlow (Eds.), The Cambridge Handbook of the Psychology of Prejudice (pp. 149-187). Cambridge: Cambridge University Press. http://doi.org/10.1017/9781316161579.008

Steenkamp, J. E. M., \& Baumgartner, H. (1998). Assessing Measurement Invariance in Cross-National Consumer Research. Journal of Consumer Research, 25(1), 78-107. http://doi.org/10.1086/209528

Swami, V., Barron, D., Weis, L., \& Furnham, A. (2018). To Brexit or not to Brexit: The roles of Islamophobia, conspiracist beliefs, and integrated threat in voting intentions for the United 
NATURE OF ISLAMOPHOBIA

Kingdom European Union membership referendum. British Journal of Psychology, 109(1), 156-179. http://doi.org/10.1111/bjop.12252

Thomsen, L., Green, E. G. T., \& Sidanius, J. (2008). We will hunt them down: How social dominance orientation and right-wing authoritarianism fuel ethnic persecution of immigrants in fundamentally different ways. Journal of Experimental Social Psychology, 44(6), 1455-1464. http://doi.org/10.1016/j.jesp.2008.06.011

Tonidandel, S., \& LeBreton, J. M. (2015, June 1). RWA Web: A Free, Comprehensive, WebBased, and User-Friendly Tool for Relative Weight Analyses. Journal of Business and Psychology. Springer New York LLC. https://doi.org/10.1007/s10869-014-9351-z

Uenal, F. (2016a). Disentangling Islamophobia: The differential effects of symbolic, realistic, and terroristic threat perceptions as mediators between social dominance orientation and Islamophobia. Journal of Social and Political Psychology, 4(1), 66-90. https://doi.org/10.5964/jspp.v4i1.463

Uenal, F. (2016b). The "Secret Islamization" of Europe: Exploring Integrated Threat Theory for Predicting Islamophobic Conspiracy Stereotypes. International Journal of Conflict and Violence, 10(1), 93-108. https://doi.org/10.41119/UNIBI/ijcv.499

Uenal, F. (2016c). Islamophobia \& Anti-Semitism. Comparing the social psychological underpinnings of Anti-Semitic and Anti-Muslim Beliefs in Contemporary Germany. Islamophobia Studies Journal, 3(2), 35-55.

United Nations. (2018, March 6). "No other conclusion," ethnic cleansing of Rohingyas in Myanmar continues - senior UN rights official. UN News. Retrieved April 3, 2018, from https://news.un.org/en/story/2018/03/1004232

van Prooijen, J.-W., \& Douglas, K. M. (2018). Belief in conspiracy theories: Basic principles of 
an emerging research domain. European Journal of Social Psychology, 48(7), 897-908. https://doi.org/10.1002/ejsp.2530

Whitson, J. A., \& Galinsky, A. D. (2008). Lacking Control Increases Illusory Pattern Perception. Science, 322(5898), 115-117. http://doi.org/10.1126/science.1159845

Wilson, G. D. (1973). The Psychology of Conservatism. London, UK: Academic Press.

Zia-Ebrahimi, R. (2018). When the Elders of Zion relocated to Eurabia: conspiratorial racialization in antisemitism and Islamophobia. Patterns of Prejudice, 52(4), 314-337. https://doi.org/10.1080/0031322X.2018.1493876 
NATURE OF ISLAMOPHOBIA

\title{
Footnotes
}

\begin{abstract}
${ }^{1}$ Only main effects and two-way interactions were predicted. However, we also conducted analyses with all possible and meaningful interactions. These interactions were not significant, and did not improve the predictive ability of the models. These higher-order interactions are not discussed in this paper.

${ }^{2}$ In two out of the three regression analyses the anti-Islam sentiment subcomponent shows a negative regression coefficient. However, running the analyses without the other two subcomponents indicates that anti-Islam sentiment has a significant and positive effect on the outcome variables. Given the high intercorrelation between the subcomponents, these results are due to multicollinearity and thus the negative coefficient can be interpreted as suppression effect rather than a true negative effect.
\end{abstract}




\section{SUPPLEMENTAL ONLINE MATERIALS: NATURE OF ISLAMOPHOBIA}

\section{Supplemental Online Materials}

The nature of Islamophobia: A test of a tripartite view in five countries 


\section{SUPPLEMENTAL ONLINE MATERIALS: NATURE OF ISLAMOPHOBIA}

S1

Participants and Power Analysis Across all Studies and Analyses.

Study 1 - Confirmatory Factor Analyses and Measurement invariance Analyses (Table 2, and Tables S8-S9 in the SOM)

In contrast to experimental studies there is still a lack of clear guidance and commonly accepted rules and techniques when it comes to determine adequate sample size for confirmatory factor analyses (CFA; e.g., Putnick \& Bornstein, 2016). For instance, older approaches suggested aiming for a 5:1 or 10:1 ratio of observations to parameter estimates (or constructs). However, these approaches have been shown to be inadequate (e.g. Little, 2013). Other approaches such as Monte Carlo simulation studies on the other hand do not account for the complexities when it comes to more complex CFAs such as multi-group CFA research designs. Nevertheless, key factors in determining the required sample size include, besides other factors, the reliability of the measured scales and the convergent and discriminant validity of the indicators and the constructs (ibid.). In a previous study (Uenal, 2016c), an earlier version of the Tripartite Islamophobia Scale showed good reliability, as well as good discriminant and convergent validity. Given these preliminary results, we decided to rely on an absolute sample size guideline. Following the recommendations by Little (2013) and Meade and Bauer (2007), we chose a medium size sample size of 300 individuals per population. Our final sample of 1,466 therefore represents a size that is adequate according to the consulted literature. 


\section{SUPPLEMENTAL ONLINE MATERIALS: NATURE OF ISLAMOPHOBIA}

Study 1 - Hierarchical Regression Analyses (Intergroup Emotions and TIS) (Tables 3-5, and Tables S6-S7 and S10-S11 in the SOM)

As determined via power analyses (G*Power, Faul et al., 2009; Linear multiple regression: Fixed model, $R^{2}$ increase), a total of 292 participants per population and 1460 participants for five countries in total would be needed to have an $80 \%$ chance to observe an effect of small size $\left(f^{2}=.04\right)$.

Hence, to satisfy this criterion and leave some flexibility to exclude inattentive participants, we aim at recruiting 1500 participants via Amazon Mechanical Turk and/or PROLIFIC services for an online study.

Study 2 - Hierarchical Regression analyses (SDO*ID*Emotions, and TIS) (Table 7)

As determined via power analyses (G*Power, Faul et al., 2009; Linear multiple regression: Fixed model, $R^{2}$ increase), a total of 187 participants in total would be needed to have an $80 \%$ chance to observe an interaction effect of small to medium size $\left(f^{2}=.05\right)$. Hence, to satisfy this criterion and leave some flexibility to exclude inattentive participants, we aim at recruiting 230 participants via Amazon Mechanical Turk for an online study.

Study 2 - Hierarchical Regression Analyses (Demographics, SDO, ID, Political Orientation, and TIS on Criterion Variables) (Table 8) As determined via power analyses (G*Power, Faul et al., 2009; Linear multiple regression: Fixed model, $R^{2}$ increase), a total of 212 participants in total would be needed to have an $80 \%$ chance to observe an interaction effect of small to medium size $\left(R^{2}=.05\right)$. Hence, to satisfy this criterion and leave some flexibility to exclude inattentive participants, we aim at recruiting 230 participants via Amazon Mechanical Turk for an online study. 


\section{SUPPLEMENTAL ONLINE MATERIALS: NATURE OF ISLAMOPHOBIA}

Table S2

Socio-Demographic Composition of Samples (Samples 1-5: $N=1466$; Sample 6: $N=213$ ).

\section{Country - Demographics}

Mean SD Min Max N

\section{Sample 1 USA $(n=295)$}

Age $(1=$ Low $-8=$ High $)$

Gender $(1=$ Male $/ 2=$ Female $/ 3=$ Other $)$

$\begin{array}{lllll}4.14 & 1.29 & 2 & 8 & 295\end{array}$

Education $(1=$ Low $-8=$ High $)$

Household Income $(1=$ Low $-9=$ High $)$

$\begin{array}{lllll}1.46 & 0.51 & 1 & 3 & 295\end{array}$

Political Orientation $(1=$ Liberal $/$ Left $-7=$ Conservative $/$ Right $)$

$\begin{array}{lllll}4.34 & 1.34 & 1 & 8 & 295 \\ 3.92 & 1.63 & 1 & 9 & 295 \\ 2.78 & 1.22 & 1 & 5 & 295\end{array}$

\section{Sample 2 Germany $(n=293)$}

$$
\begin{aligned}
& \text { Age }(1=\text { Low }-8=\text { High }) \\
& \text { Gender }(1=\text { Male } / 2=\text { Female } / 3=\text { Other }) \\
& \text { Education }(1=\text { Low }-8=\text { High }) \\
& \text { Household Income }(1=\text { Low }-9=\text { High })
\end{aligned}
$$

$\begin{array}{lllll}2.99 & 0.99 & 2 & 7 & 293 \\ 1.39 & 0.49 & 1 & 3 & 293 \\ 7.37 & 1.08 & 1 & 11 & 293 \\ 2.97 & 1.62 & 1 & 8 & 290\end{array}$


SUPPLEMENTAL ONLINE MATERIALS: NATURE OF ISLAMOPHOBIA

Political Orientation $(1=$ Liberal $/$ Left $-7=$ Conservative $/$ Right $)$

\section{Sample 3 Poland $(n=297)$}

Age $(1=$ Low $-8=$ High $)$

Gender $(1=$ Male $/ 2=$ Female $/ 3=$ Other $)$

Education $(1=$ Low $-8=$ High $)$

Household Income $(1=$ Low $-9=$ High $)$

Political Orientation $(1=$ Liberal $/$ Left $-7=$ Conservative $/$ Right $)$

$\begin{array}{lllll}2.70 & 0.86 & 2 & 6 & 297 \\ 1.31 & 0.48 & 1 & 3 & 297 \\ 6.63 & 1.78 & 3 & 10 & 297 \\ 2.43 & 1.33 & 1 & 8 & 294 \\ 3.09 & 0.86 & 1 & 5 & 297\end{array}$

\section{Sample 4 France $(n=288)$}

Age $(1=$ Low $-8=$ High $)$

$\begin{array}{ccccc}3.44 & 1.19 & 2 & 7 & 297 \\ 1.72 & 0.46 & 1 & 3 & 297 \\ 4.76 & 2.96 & 1 & 11 & 297 \\ 3.40 & 2.33 & 1 & 10 & 294 \\ 2.56 & 0.92 & 1 & 5 & 297\end{array}$

\section{Sample 5 India $(n=293)$}

Age $(1=$ Low $-8=$ High $)$

Gender $(1=$ Male $/ 2=$ Female $/ 3=$ Other $)$

$\begin{array}{lllll}3.96 & 1.17 & 2 & 7 & 293 \\ 1.42 & 0.49 & 1 & 2 & 293\end{array}$




\section{SUPPLEMENTAL ONLINE MATERIALS: NATURE OF ISLAMOPHOBIA}

Education $(1=$ Low $-8=$ High $)$

Household Income ( 1 = Low $-9=$ High $)$

$\begin{array}{lllll}3.90 & 1.51 & 1 & 10 & 293\end{array}$

Political Orientation $(1=$ Liberal $/$ Left $-7=$ Conservative $/$ Right $)$

$\begin{array}{llll}2.88 & 1.23 \quad 1 \quad 5\end{array}$

293

\section{Sample 6 USA $(n=213)$}

Age $(1=$ Low $-8=$ High $)$

$\begin{array}{lllll}3.70 & 1.17 & 2 & 7 & 213\end{array}$

Gender $(1=$ Male $/ 2=$ Female $/ 3=$ Other $)$

$\begin{array}{lllll}1.47 & 0.50 & 1 & 3 & 213\end{array}$

Education $(1=$ Low $-8=$ High $)$

$\begin{array}{lllll}4.09 & 1.35 & 1 & 8 & 213\end{array}$

Household Income ( $1=$ Low $-9=$ High $)$

Political Orientation $(1=$ Liberal $/$ Left $-5=$ Conservative $/$ Right $)$

$\begin{array}{lllll}2.13 & 1.42 & 1 & 5 & 213\end{array}$

Notes. Due to data quality issues pertaining to online participants from Amazon MTurk, we included a quality check to sort out bots and otherwise non-sensical and / or random data. Participants were asked to answer an attention check question by choosing one specific answer option at the beginning of the survey. Due to known issues with bots and other issues for the MTurk participants pool in India, we included two additional attention checks into the survey; one additional at the beginning, and one in the middle of the survey (e.g., "To monitor the quality, please press 3 on the following scale.”). Participants who failed one and more quality checks were sorted out. Also, participants who finished the survey in an unreasonably short amount of time ( $>180$ seconds) were sorted out. In total 34 participants for Study 1 were removed due to failed attention checks or other quality measures of the survey (USA: 5; Germany: 7; India: 7; France: 12; Poland: 3). In Study 2, 17 participants were removed. 
SUPPLEMENTAL ONLINE MATERIALS: NATURE OF ISLAMOPHOBIA

Table S3

Indicators of the Tripartite Islamophobia Scale used in all Samples.

\begin{tabular}{llll}
\hline Overarching & First-Order & Definition & Questionnaire items, each with five \\
Concept & Concept & & response options:
\end{tabular}

\begin{tabular}{|c|c|c|c|c|}
\hline \multirow{6}{*}{$\begin{array}{l}\text { Tripartite } \\
\text { Islamophobia }\end{array}$} & Anti-Islam & Indiscriminate and negative & 1) Islam is a sexist religion. & 1 - "Strongly disagree" \\
\hline & & & $\begin{array}{l}\text { 3) The Islamic religion is harmful for } \\
\text { world peace. }\end{array}$ & $\begin{array}{l}4 \text { - "Somewhat agree" } \\
5 \text { - "Strongly agree" }\end{array}$ \\
\hline & & & 4) The Islamic religion is by default & \\
\hline & & & not compatible with modernity. & \\
\hline & & & 5) Islam is an anti-semitic religion. & \\
\hline & & & 6) Islam has produced an admirable & \\
\hline
\end{tabular}




\section{SUPPLEMENTAL ONLINE MATERIALS: NATURE OF ISLAMOPHOBIA}

7) Islamic culture fits perfectly in our

\section{Western World.*}

Anti-Muslim Indiscriminate and negative 1) The Islamist terrorists find strong 1 - "Strongly disagree"

Prejudice attitudes towards Muslim Support among Muslims. $\quad 2$ - "Somewhat disagree"

individuals.

2) Muslims are not trustworthy.

3 - "Neither agree nor disagree"

3) Muslims attract more attention

4 - "Somewhat agree"

due to their aggressive behavior.

5 - "Strongly agree"

4) Muslims are a social and

economic burden for [Respondents

Country].

5) Muslims appear to be rather irrational, compared to non-Muslims

in this country.

6) Muslim practices fit perfectly in

our [Residents Country].* 


\section{SUPPLEMENTAL ONLINE MATERIALS: NATURE OF ISLAMOPHOBIA}

7) Muslims are an enrichment for the

\section{[Residents Country].*}

Anti-Muslim Conspiracy beliefs

Conspiracy

Beliefs
1) Muslims are planning to Islamize the West step by step.

2) Actually, Muslims are striving to establish the Sharia in the

[Respondents Country].

3) Muslims secretly plot for an

Islamization of [Residents

Country]

4) Muslims would like to control the international political institutions.

5) Muslims achieve their collective goals by secret agreements. 


\section{SUPPLEMENTAL ONLINE MATERIALS: NATURE OF ISLAMOPHOBIA}

Notes. The original German items were translated into English, Polish, and French from German or English and back-translated by native speakers and/or professional translators. Many thanks to Dr. Katarzyna Wojnicka and Dr. Katarzyna Jaśko for the Polish translations. Gratitude to Dr. Pascale Roure and Camille Barras MA for the French translations. The translated items are listed below (Tables S14-S15).

* Reverse coded items 


\section{SUPPLEMENTAL ONLINE MATERIALS: NATURE OF ISLAMOPHOBIA}

Table S4

Studies 1 and 2 -Reliability Indicator for TIS Single-Country Analysis (Samples 1-5, USA, Germany, Poland, France and India: N = 1466; Sample

6, USA: $N=213)$.

\begin{tabular}{|c|c|c|c|}
\hline Study & Country & Constructs & $\alpha$ \\
\hline \multirow{3}{*}{ Study 1 Aggregated } & & Conspiracy Beliefs & .95 \\
\hline & & Disgust Islam \& Muslims & .97 \\
\hline & & Fear of Islam and Muslims & .97 \\
\hline \multicolumn{4}{|c|}{ Study 1 Single Country Analysis } \\
\hline & & Conspiracy Beliefs & .95 \\
\hline
\end{tabular}


SUPPLEMENTAL ONLINE MATERIALS: NATURE OF ISLAMOPHOBIA

Anger Islam \& Muslims 


\section{India}

Anti-Islam Sentiment 
SUPPLEMENTAL ONLINE MATERIALS: NATURE OF ISLAMOPHOBIA

Anger Islam \& Muslims

Disgust Islam \& Muslims

Fear of Islam and Muslims

Study 2

USA
$(n=213)$
Anti-Islam Sentiment

Anti-Muslim prejudice

Conspiracy Beliefs

Anger Islam \& Muslims

Disgust Islam \& Muslims

Fear of Islam and Muslims
.91

.92

.97

.97

.97

.97 


\section{SUPPLEMENTAL ONLINE MATERIALS: NATURE OF ISLAMOPHOBIA}

\section{Table S5}

Means, Standard Deviations, and Intercorrelations Between all Variables Across Samples in Study 1.

\begin{tabular}{|c|c|c|c|c|c|c|c|c|c|c|c|c|c|c|}
\hline & $M$ & $(S D)$ & 1 & 2 & 3 & 4 & 5 & 6 & 7 & 8 & 9 & 10 & 11 & 12 \\
\hline 1. Tripartite Islamophobia Scale & 2.01 & 0.97 & - & & & & & & & & & & & \\
\hline 2. Anti-Muslim Prejudice & 3.73 & 1.07 & $.26^{* *}$ & & & & & & & & & & & \\
\hline 3. Anti-Islam Sentiment & 2.13 & 1.42 & $.53 * *$ & $.34 * *$ & & & & & & & & & & \\
\hline 4. Conspiracy Beliefs & 2.23 & 1.37 & $.39 * *$ & $.31^{* *}$ & $.33^{* *}$ & & & & & & & & & \\
\hline 5. Fear of Islam & 2.12 & 1.32 & $.45^{* *}$ & $.31 * *$ & $.45^{* *}$ & $.84 * *$ & & & & & & & & \\
\hline 6. Fear of Muslims & 2.27 & 1.34 & $.43^{* *}$ & $.24 * *$ & $.40 * *$ & $.78 * *$ & $.70 * *$ & & & & & & & \\
\hline 7. Anger toward Islam & 1.98 & 1.23 & $.53 * *$ & $.28 * *$ & $.54 * *$ & $.72 * *$ & $.83^{* *}$ & $.81 * *$ & & & & & & \\
\hline 8. Anger toward Muslims & 2.17 & 1.34 & $.44 * *$ & $.22 * *$ & $.42 * *$ & $.75^{* *}$ & $.71 * *$ & $.93 * *$ & $.83 * *$ & & & & & \\
\hline 9. Disgust of Islam & 1.94 & 1.27 & $.55^{* *}$ & $.27 * *$ & $.50 * *$ & $.71 * *$ & $.79 * *$ & $.79 * *$ & $.94 * *$ & $.85^{* *}$ & & & & \\
\hline 10. Disgust of Muslims & 2.17 & 1.29 & $.44 * *$ & $.32 * *$ & $.40 * *$ & $.96^{* *}$ & $.96^{* *}$ & $.77 * *$ & $.80 * *$ & $.76^{* *}$ & $.78 * *$ & & & \\
\hline 11. Fear Islam \& Muslims & 2.12 & 1.23 & $.50 * *$ & $.27 * *$ & $.49 * *$ & $.79 * *$ & $.80 * *$ & $.96 * *$ & $.95^{* *}$ & $.93 * *$ & $.91 * *$ & $.83^{* *}$ & & \\
\hline 12. Anger Islam \& Muslims & 2.06 & 1.26 & $.51 * *$ & $.25^{* *}$ & $.47 * *$ & $.76^{* *}$ & $.78^{* *}$ & $.90 * *$ & $.91 * *$ & $.97 * *$ & $.96^{* *}$ & $.80 * *$ & $.95^{* *}$ & \\
\hline 13. Disgust Islam \& Muslims & 2.50 & 0.96 & $.36^{* *}$ & $.34 * *$ & $.43^{* *}$ & $.62 * *$ & $.61^{* *}$ & $.76^{* *}$ & $.70 * *$ & $.75^{* *}$ & $.66^{* *}$ & $.64 * *$ & $.77 * *$ & $.73 * *$ \\
\hline
\end{tabular}

$* * p<.01$. 


\section{SUPPLEMENTAL ONLINE MATERIALS: NATURE OF ISLAMOPHOBIA}

Table S6

Regression Results Using the Tripartite Islamophobia Scale as the Criterion Variable $(n=1466)$.

\begin{tabular}{|c|c|c|c|c|c|c|c|c|c|c|}
\hline Country & Predictor & $b$ & $\begin{array}{c}b \\
95 \% \text { CI } \\
{[\text { LL, UL] }}\end{array}$ & beta & $\begin{array}{c}\text { beta } \\
95 \% \text { CI } \\
{[\mathrm{LL}, \mathrm{UL}]} \\
\end{array}$ & $s r^{2}$ & $\begin{array}{c}s r^{2} \\
95 \% \text { CI } \\
{[\mathrm{LL}, \mathrm{UL}]}\end{array}$ & $r$ & Fit & Difference \\
\hline \multirow{12}{*}{$\begin{array}{l}5 \text { Countries } \\
(\mathrm{N}=1466)\end{array}$} & Step 1 & & & & & & & & \multirow{3}{*}{$\begin{array}{l}\text { Adj. } R^{2}=.575 * * \\
95 \% \mathrm{CI}[.55, .60]\end{array}$} & \multirow{7}{*}{$\begin{array}{c}\Delta R^{2}=.115^{* *} \\
95 \% \mathrm{CI}[.09, .13]\end{array}$} \\
\hline & Fear of Islam & $0.38 * *$ & {$[0.33,0.44]$} & 0.45 & {$[0.38,0.51]$} & .05 & {$[.04, .07]$} & $.74 * *$ & & \\
\hline & Fear of Muslims & $0.29 * *$ & {$[0.24,0.35]$} & 0.34 & {$[0.28,0.40]$} & .03 & {$[.02, .04]$} & $.72 * *$ & & \\
\hline & (Intercept) & $1.01 * *$ & {$[0.95,1.08]$} & & & & & & \multirow{4}{*}{$\begin{array}{l}\text { Adj. } R^{2}=.690 * * \\
95 \% \text { CI }[.67, .71]\end{array}$} & \\
\hline & Fear of Islam & $0.17 * *$ & {$[0.12,0.23]$} & 0.20 & {$[0.14,0.27]$} & .01 & {$[.00, .01]$} & $.74 * *$ & & \\
\hline & Fear of Muslims & $0.11 * *$ & {$[0.06,0.17]$} & 0.13 & {$[0.07,0.20]$} & .00 & {$[-.00, .01]$} & $.72 * *$ & & \\
\hline & Anger toward Islam & $0.32 * *$ & {$[0.26,0.38]$} & 0.36 & {$[0.29,0.42]$} & .03 & {$[.02, .03]$} & $.79 * *$ & & \\
\hline & (Intercept) & $1.00 * *$ & {$[0.94,1.07]$} & & & & & & \multirow{5}{*}{$\begin{array}{l}\text { Adj. } R^{2}=.693 * * \\
95 \% \text { CI }[.67, .71]\end{array}$} & \multirow{5}{*}{$\begin{array}{c}\Delta R^{2}=.004 * * \\
95 \% \text { CI }[.00, .01]\end{array}$} \\
\hline & Fear of Islam & $0.16^{* *}$ & {$[0.11,0.22]$} & 0.19 & {$[0.13,0.26]$} & .01 & {$[.00, .01]$} & $.74 * *$ & & \\
\hline & Fear of Muslims & $0.12 * *$ & {$[0.06,0.18]$} & 0.14 & {$[0.07,0.21]$} & .00 & {$[.00, .01]$} & $.72 * *$ & & \\
\hline & Anger toward Islam & $0.25 * *$ & {$[0.18,0.31]$} & 0.28 & {$[0.20,0.35]$} & .01 & {$[.01, .02]$} & $.79^{* *}$ & & \\
\hline & Anger toward Muslims & $0.18 * *$ & {$[0.10,0.25]$} & 0.19 & {$[0.11,0.28]$} & .00 & {$[.00, .01]$} & $.76^{* *}$ & & \\
\hline
\end{tabular}




\section{SUPPLEMENTAL ONLINE MATERIALS: NATURE OF ISLAMOPHOBIA}

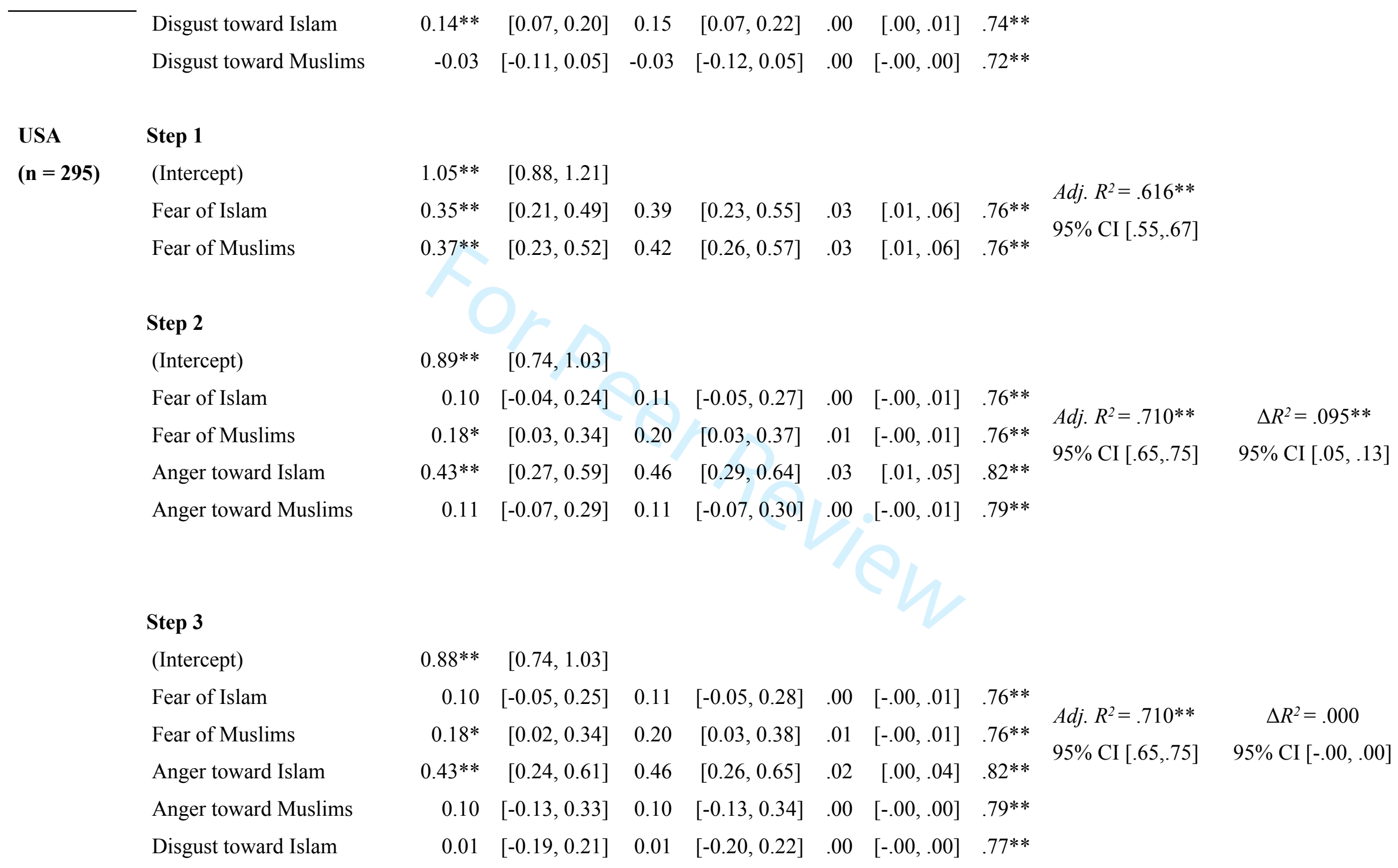




\section{SUPPLEMENTAL ONLINE MATERIALS: NATURE OF ISLAMOPHOBIA}

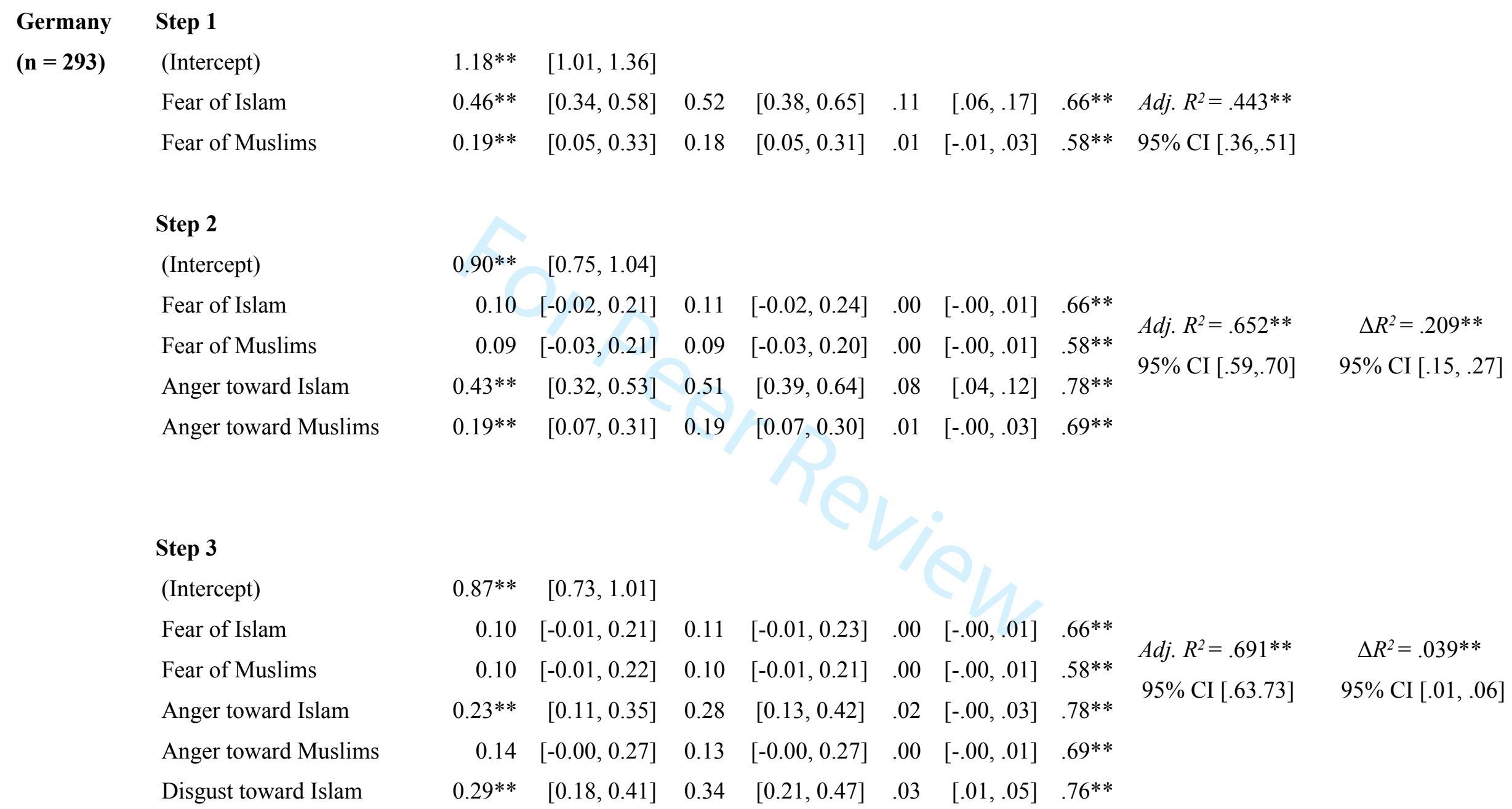

\section{Step 3}

(Intercept)

Fear of Islam

Fear of Muslims

Anger toward Islam

Anger toward Muslims

Disgust toward Islam

Poland Step 1 


\section{SUPPLEMENTAL ONLINE MATERIALS: NATURE OF ISLAMOPHOBIA}

\begin{tabular}{|c|c|c|c|c|c|c|c|c|c|c|}
\hline \multirow[t]{15}{*}{$(n=297)$} & (Intercept) & $2.07 * *$ & {$[1.87,2.26]$} & & & & & & Adj. $R^{2}=.417^{* *}$ & \\
\hline & Fear of Islam & $0.28 * *$ & {$[0.17,0.39]$} & 0.40 & {$[0.25,0.56]$} & .05 & {$[.01, .09]$} & $.63 * *$ & $95 \%$ CI $[.33, .49]$ & \\
\hline & Fear of Muslims & $0.18^{* *}$ & {$[0.08,0.28]$} & 0.27 & {$[0.12,0.43]$} & .02 & {$[-.00, .05]$} & $.60 * *$ & & \\
\hline & $\begin{array}{l}\text { Step } 2 \\
\text { (Intercept) }\end{array}$ & $1.82 * *$ & {$[1.64,1.99]$} & & & & & & \multirow{5}{*}{$\begin{array}{l}\text { Adj. } R^{2}=.568 * * \\
95 \% \text { CI }[.49, .62]\end{array}$} & \multirow{5}{*}{$\begin{array}{c}\Delta R^{2}=.151 * * \\
95 \% \text { CI }[.09, .21]\end{array}$} \\
\hline & Fear of Islam & $0.16^{* *}$ & {$[0.06,0.26]$} & 0.23 & {$[0.08,0.37]$} & .01 & {$[-.00, .03]$} & $.63 * *$ & & \\
\hline & Fear of Muslims & 0.07 & {$[-0.02,0.17]$} & 0.11 & {$[-0.04,0.25]$} & .00 & {$[-.01, .01]$} & $.60 * *$ & & \\
\hline & Anger toward Islam & $0.19 * *$ & {$[0.08,0.29]$} & 0.26 & {$[0.12,0.41]$} & .02 & {$[-.00, .04]$} & $.68 * *$ & & \\
\hline & Anger toward Muslims & $0.18 * *$ & {$[0.08,0.28]$} & 0.27 & {$[0.12,0.41]$} & .02 & {$[-.00, .04]$} & $.68 * *$ & & \\
\hline & \multicolumn{10}{|l|}{ Step 3} \\
\hline & (Intercept) & $1.81 * *$ & {$[1.63,1.99]$} & & & & & & & \multirow{6}{*}{$\begin{array}{c}\Delta R^{2}=.001 \\
95 \% \text { CI }[-.00, .01]\end{array}$} \\
\hline & Fear of Islam & $0.16^{* *}$ & {$[0.06,0.26]$} & 0.23 & {$[0.09$} & .01 & {$[-.00, .03]$} & $.63 * *$ & \multirow{5}{*}{$\begin{array}{l}\text { Adj. } R^{2}=.569 * * \\
95 \% \text { CI }[.49, .62]\end{array}$} & \\
\hline & Fear of Muslims & 0.07 & {$[-0.02,0.17]$} & 0.11 & {$[-0.04,0.25]$} & .00 & {$[-.01, .01]$} & $.60 * *$ & & \\
\hline & Anger toward Islam & $0.16^{* *}$ & {$[0.05,0.28]$} & 0.23 & {$[0.07,0.40]$} & .01 & {$[-.00, .03]$} & $.68^{* *}$ & & \\
\hline & Anger toward Muslims & $0.16^{* *}$ & {$[0.04,0.28]$} & 0.24 & {$[0.06,0.42]$} & .01 & {$[-.00, .03]$} & $.68^{* *}$ & & \\
\hline & Disgust toward Islam & 0.04 & {$[-0.08,0.16]$} & 0.06 & {$[-0.11,0.22]$} & .00 & {$[-.00, .00]$} & $.60 * *$ & & \\
\hline \multirow{3}{*}{$\begin{array}{l}\text { France } \\
(n=289)\end{array}$} & Step 1 & & & & & & & & & \\
\hline & (Intercept) & $1.01 * *$ & {$[0.87,1.15]$} & & & & & & \multicolumn{2}{|l|}{ Adj. $R^{2}=.606^{* *}$} \\
\hline & Fear of Islam & $0.37 * *$ & {$[0.28,0.47]$} & 0.47 & {$[0.35,0.58]$} & .08 & {$[.04, .12]$} & $.75^{* *}$ & \multicolumn{2}{|l|}{$95 \%$ CI [.54,.66] } \\
\hline
\end{tabular}




\section{SUPPLEMENTAL ONLINE MATERIALS: NATURE OF ISLAMOPHOBIA}

$\begin{array}{lllllllll}\text { Fear of Muslims } & 0.33^{* *} & {[0.22,0.44]} & 0.36 & {[0.24,0.48]} & .05 & {[.02, .08]} & .72 * *\end{array}$

\section{Step 2}

(Intercept)

Fear of Islam

Fear of Muslims

Anger toward Islam

Anger toward Muslims

$0.81 * * \quad[0.69,0.93]$

$\begin{array}{llllllll}0.14 * & {[0.03,0.24]} & 0.17 & {[0.03,0.30]} & .01 & {[-.00, .01]} & .75 * *\end{array}$

$\begin{array}{llllllll}0.15^{*} & {[0.02,0.28]} & 0.16 & {[0.02,0.30]} & .00 & {[-.00, .01]} & .72 * *\end{array}$

$\begin{array}{llllllll}0.38 * * & {[0.26,0.50]} & 0.43 & {[0.29,0.56]} & .04 & {[.01, .06]} & .81 * *\end{array}$

Adj. $R^{2}=.733^{* *} \quad \Delta R^{2}=.127^{* *}$

$95 \%$ CI $[.68, .77] \quad 95 \%$ CI $[.08, .17]$

$0.20 * * \quad[0.06,0.34] \quad 0.19 \quad[0.05,0.33] \quad .01 \quad[-.00, .02] \quad .76^{* *}$

\section{Step 3}

(Intercept)

Fear of Islam

Fear of Muslims

Anger toward Islam

Anger toward Muslims

Disgust toward Islam

\begin{tabular}{|c|c|c|c|c|c|c|}
\hline $6^{*}$ & {$[0.64$,} & & & & & \\
\hline 0.14 & {[} & & ] & .01 & {$[-.00, .01]$} & 7. \\
\hline $0.14^{*}$ & {$[0.01$,} & 0.16 & {$[0.01,0.30]$} & .00 & {$[-.00, .01]$} & $.72^{*}$ \\
\hline $25^{*}$ & {$[0.1$} & 0.28 & {$[0.13$,} & .01 & {$[-.00, .03]$} & .81 \\
\hline 0.05 & {$[-0.12,0.21]$} & 0.05 & {$[-0.12,0.21]$} & .00 & {$[-.00, .00]$} & $.76^{*}$ \\
\hline $22 * *$ & {$[0.09,0.35]$} & 0.22 & 35] & .01 & {$[-.00, .02]$} & .79 \\
\hline
\end{tabular}

Adj. $R^{2}=.751^{* *} \quad \Delta R^{2}=.018^{* *}$

$95 \%$ CI $[.70, .78] \quad 95 \%$ CI $[.00, .03]$

\section{India Step 1}

(n= 292) (Intercept)

Fear of Islam

Fear of Muslims

$\begin{array}{llllllll}1.29^{* *} & {[1.12,1.46]} & & & & & & \\ 0.40^{* *} & {[0.26,0.55]} & 0.47 & {[0.31,0.64]} & .04 & {[.01, .08]} & .75^{* *} & \begin{array}{l}\text { Adj. } R^{2}=.584^{* *} \\ 0.27 * *\end{array} \\ {[0.12,0.41]} & 0.31 & {[0.14,0.48]} & .02 & {[-.00, .04]} & .73^{* *} & 95 \% \text { CI }[.51, .64]\end{array}$




\section{SUPPLEMENTAL ONLINE MATERIALS: NATURE OF ISLAMOPHOBIA}

\section{Step 2}

(Intercept)

$1.11^{* *} \quad[0.96,1.26]$

Fear of Islam

$0.25^{* *} \quad[0.10,0.39]$

0.29

Fear of Muslims

$-0.09 \quad[-0.25,0.07]$

$.01[-.00, .03] \quad .75^{* *}$

Adj. $R^{2}=.695^{* *}$

$\Delta R^{2}=.111^{* *}$

Anger toward Islam

$0.28^{* *}$

$[0.12,0.44]$

$-0.11[-0.30,0.08]$

$.00[-.00, .01] \quad .73 * * \quad 95 \%$ CI $[.64, .73]$

$95 \%$ CI $[.07, .16]$

Anger toward Muslims

$0.33 * *$

$[0.16,0.50]$

$[0.14,0.50]$

$.01[-.00, .03] \quad .81 * *$

Anger toward Muslims

\section{Step 3}

(Intercept)

Fear of Islam

Fear of Muslims

Anger toward Islam

Anger toward Muslims

Disgust toward Islam

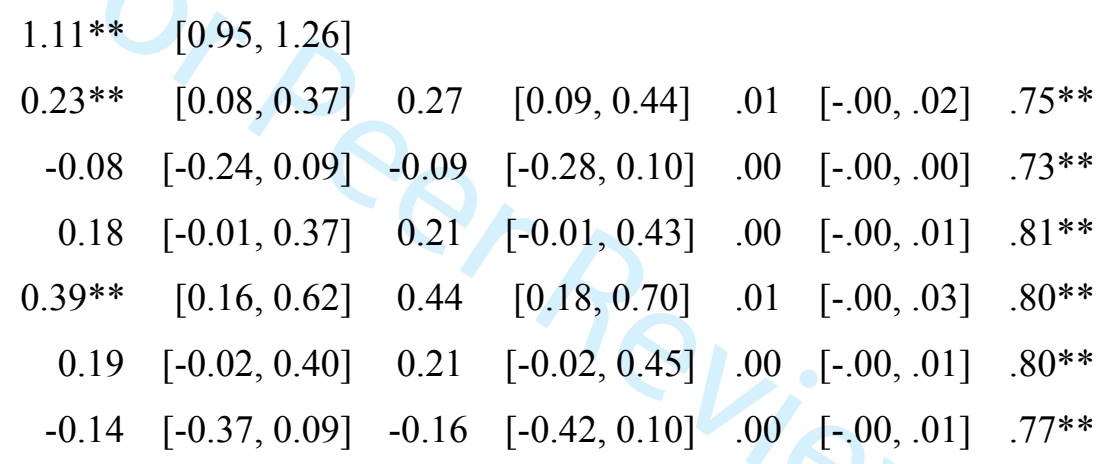

Adj. $R^{2}=.698^{* *} \quad \Delta R^{2}=.003$

$95 \%$ CI $[.64, .73] \quad 95 \%$ CI $[-.00, .01]$

Note. A significant $b$-weight indicates the beta-weight and semi-partial correlation are also significant. $b$ represents unstandardized regression weights. beta indicates the standardized regression weights. $s r^{2}$ represents the semi-partial correlation squared. $r$ represents the zero-order correlation. $L L$ and $U L$ indicate the lower and upper limits of a confidence interval, respectively.

$* p<.05 . * * p<.01$. 


\section{SUPPLEMENTAL ONLINE MATERIALS: NATURE OF ISLAMOPHOBIA}

Table S7

Regression Results Using the Tripartite Islamophobia Subscales as the Criterion Variables $(n=1466)$.

\begin{tabular}{|c|c|c|c|c|c|c|c|}
\hline \multirow[t]{2}{*}{ Country } & \multirow[t]{2}{*}{ Intergroup emotions } & \multicolumn{2}{|c|}{ Anti-Islam Sentiment } & \multicolumn{2}{|c|}{ Anti-Muslim Prejudice } & \multicolumn{2}{|c|}{ Conspiracy Beliefs } \\
\hline & & $B(\mathrm{SE})$ & $\beta$ & $B(\mathrm{SE})$ & $\beta$ & $B(\mathrm{SE})$ & $\beta$ \\
\hline \multirow{16}{*}{$\begin{array}{l}5 \text { Countries } \\
(N=1466)\end{array}$} & Step 1 & & & & & & \\
\hline & Fear of Islam & $.49 * * *(0.04)$ & .54 & $.12 * * *(0.03)$ & .13 & $.19 * * *(0.04)$ & .20 \\
\hline & Fear of Muslims & $.13 *(0.04)$ & .14 & $.13 * * *(0.03)$ & .14 & $.16^{* * *}(0.04)$ & .16 \\
\hline & $R^{2}$ & $.44 * *$ & & $.52 * *$ & & $.51 * *$ & \\
\hline & Step 2 & & & & & & \\
\hline & Anger toward Islam & $.47 * * *(0.04)$ & .50 & $.27 * * *(0.04)$ & .28 & $.11 *(0.04)$ & .11 \\
\hline & Anger toward Muslims & $.10 *(0.05)$ & .10 & $.21 * * *(0.04)$ & .22 & $.22 * * *(0.05)$ & .21 \\
\hline & $R^{2}$ & $.55 * *$ & & $.64 * *$ & & $.59 * *$ & \\
\hline & $\Delta R^{2}$ & $.11 * *$ & & $.12 * *$ & & $.08 * *$ & \\
\hline & Step 3 & & & & & & \\
\hline & Disgust toward Islam & $.25 * * *(0.04)$ & .26 & $.07(0.04)$ & .07 & $.09 *(0.04)$ & .09 \\
\hline & Disgust toward Muslims & $-.24 * * *(0.05)$ & -.24 & $.04(0.04)$ & .04 & $.10(0.05)$ & .09 \\
\hline & $R^{2}$ & $.56^{* *}$ & & $.65^{* *}$ & & $.60 * *$ & \\
\hline & $\Delta R^{2}$ & $.01 * *$ & & $.01 *$ & & $.01 * *$ & \\
\hline & $\Delta F$ & $306.40 * * *$ & & $445.30 * * *$ & & $361.30 * * *$ & \\
\hline & Step 1 & & & & & & \\
\hline \multirow{3}{*}{$\begin{array}{l}\text { USA } \\
(n=295)\end{array}$} & Fear of Islam & $.06(0.10)$ & .07 & $.06(0.08)$ & .07 & $.18(0.09)$ & .18 \\
\hline & Fear of Muslims & $.23 *(0.10)$ & .24 & $.14(0.09)$ & .15 & $.17(0.10)$ & .17 \\
\hline & $R^{2}$ & $.50 * *$ & & $.56 * *$ & & $.56^{* *}$ & \\
\hline
\end{tabular}


SUPPLEMENTAL ONLINE MATERIALS: NATURE OF ISLAMOPHOBIA

\begin{tabular}{|c|c|c|c|c|c|c|c|}
\hline & Step 2 & & & & & & \\
\hline & Anger toward Islam & $.49^{* * *}(0.12)$ & .56 & $.44 * * *(0.10)$ & .46 & $.34 * *(0.12)$ & .33 \\
\hline & Anger toward Muslims & $.08(0.14)$ & -.05 & $.07(0.13)$ & .07 & $.15(0.15)$ & .14 \\
\hline & $R^{2}$ & $.59 * *$ & & $.66^{* *}$ & & $.62 * *$ & \\
\hline & $\Delta R^{2}$ & $.09^{* *}$ & & $.11^{* *}$ & & $.06^{* *}$ & \\
\hline & Step 3 & & & & & & \\
\hline & Disgust toward Islam & $.14(0.13)$ & .14 & $-.04(0.11)$ & -.05 & $-.06(0.13)$ & -.06 \\
\hline & Disgust toward Muslims & $-.23(0.14)$ & -.22 & $.16(0.13)$ & .16 & $.09(0.14)$ & .08 \\
\hline & $R^{2}$ & $.59 * *$ & & $.67 * *$ & & $.62^{* *}$ & \\
\hline & $\Delta R^{2}$ & .00 & & .00 & & .00 & \\
\hline & $\Delta F$ & $69.74 * * *$ & & $95.90 * * *$ & & $79.13 * * *$ & \\
\hline Germany & Step 1 & & & & & & \\
\hline & Fear of Islam & $.15 *(0.07)$ & .14 & $.09(0.07)$ & .09 & $.06(0.08)$ & .06 \\
\hline & Fear of Muslims & $.03(0.07)$ & .03 & $.07(0.07)$ & .06 & $.21 *(0.08)$ & .20 \\
\hline & $R^{2}$ & $.39^{* *}$ & & $.39 * *$ & & $.31^{* *}$ & \\
\hline & Step 2 & & & & & & \\
\hline & Anger toward Islam & $.41 * * *(0.08)$ & .41 & $.21 * *(0.07)$ & .22 & $.08(0.08)$ & .09 \\
\hline & Anger toward Muslims & $.01(0.09)$ & .01 & $.26^{* *}(0.08)$ & .22 & $.14(0.09)$ & .14 \\
\hline & $R^{2}$ & $.60 * *$ & & $.61^{* *}$ & & $.40 * *$ & \\
\hline & $\Delta R^{2}$ & $.21 * *$ & & $.23 * *$ & & $.09 * *$ & \\
\hline & Step 3 & & & & & & \\
\hline & Disgust toward Islam & $0.50 * * *(0.07)$ & .48 & $0.22 * *(0.07)$ & .22 & $0.17 *(0.08)$ & .19 \\
\hline & Disgust toward Muslims & $-.28 * *(0.10)$ & -.21 & $.14(0.10)$ & .11 & $.10(0.11)$ & .09 \\
\hline
\end{tabular}


SUPPLEMENTAL ONLINE MATERIALS: NATURE OF ISLAMOPHOBIA

\begin{tabular}{|c|c|c|c|c|c|c|c|}
\hline & $R^{2}$ & $.66^{* *}$ & & $.65^{* *}$ & & $.42 * *$ & \\
\hline & $\Delta R^{2}$ & $.06^{* *}$ & & $.03 * *$ & & $.02 * *$ & \\
\hline & $\Delta F$ & $90.71 * * *$ & & $87.14 * * *$ & & $34.89 * * *$ & \\
\hline \multirow{15}{*}{$\begin{array}{l}\text { Poland } \\
(n=297)\end{array}$} & Step 1 & & & & & & \\
\hline & Fear of Islam & $.16^{*}(0.06)$ & .22 & $.14 *(0.06)$ & .18 & $.18 *(0.07)$ & .21 \\
\hline & Fear of Muslims & $.03(0.06)$ & .05 & $.10(0.06)$ & .13 & $.08(0.07)$ & .10 \\
\hline & $R^{2}$ & $.25^{* *}$ & & $.38 * *$ & & $.34 * *$ & \\
\hline & Step 2 & & & & & & \\
\hline & Anger toward Islam & $.13(0.07)$ & .18 & $.25 * * *(0.07)$ & .31 & $.11(0.08)$ & .13 \\
\hline & Anger toward Muslims & $.17 *(0.08)$ & .24 & $.17 *(0.07)$ & .23 & $.14(0.08)$ & .17 \\
\hline & $R^{2}$ & $.34 * *$ & & $.53 * *$ & & $.45^{* *}$ & \\
\hline & $\Delta R^{2}$ & $.09 * *$ & & $.15^{* *}$ & & $.12 * *$ & \\
\hline & Step 3 & & & & & & \\
\hline & Disgust toward Islam & $.10(0.07)$ & .13 & $-.04(0.07)$ & -.05 & $0.07(0.08)$ & .08 \\
\hline & Disgust toward Muslims & $-.11(0.08)$ & -.14 & $.03(0.08)$ & .04 & $.10(0.09)$ & .11 \\
\hline & $R^{2}$ & $.35^{* *}$ & & $.53 * *$ & & $.46^{* *}$ & \\
\hline & $\Delta R^{2}$ & .00 & & .00 & & .01 & \\
\hline & $\Delta F$ & $25.91 * * *$ & & $54.61 * * *$ & & $41.16^{* * *}$ & \\
\hline \multirow{4}{*}{$\begin{array}{l}\text { France } \\
(n=289)\end{array}$} & Step 1 & & & & & & \\
\hline & Fear of Islam & $.14(0.08)$ & .16 & $.06(0.06)$ & .08 & $.21 * *(0.08)$ & .22 \\
\hline & Fear of Muslims & $.14(0.09)$ & .14 & $.18 *(0.07)$ & .18 & $.11(0.09)$ & .11 \\
\hline & $R^{2}$ & $.46^{* *}$ & & $.56^{* *}$ & & $.52 * *$ & \\
\hline
\end{tabular}


SUPPLEMENTAL ONLINE MATERIALS: NATURE OF ISLAMOPHOBIA

\begin{tabular}{|c|c|c|c|c|c|c|c|}
\hline & Step 2 & & & & & & \\
\hline & Anger toward Islam & $.44 * * *(0.09)$ & .45 & $.22 * *(0.07)$ & .24 & $.09(0.09)$ & .09 \\
\hline & Anger toward Muslims & $-.08(0.12)$ & -.07 & $.05(0.09)$ & .05 & $.17(0.12)$ & .14 \\
\hline & $R^{2}$ & $.57 * *$ & & $.70 * *$ & & $.62 * *$ & \\
\hline & $\Delta R^{2}$ & $.11^{* *}$ & & $.14^{* *}$ & & $.10^{* *}$ & \\
\hline & Step 3 & & & & & & \\
\hline & Disgust toward Islam & $0.30 * *(0.09)$ & .28 & $0.16 *(0.07)$ & .15 & $0.20 *(0.09)$ & .17 \\
\hline & Disgust toward Muslims & $-.18(0.12)$ & -.15 & $.29 * *(0.09)$ & .26 & $.22(0.12)$ & .18 \\
\hline & $R^{2}$ & $.59 * *$ & & $.72 * *$ & & $.64 * *$ & \\
\hline & $\Delta R^{2}$ & $.02 * *$ & & $.02 * *$ & & $.02 * *$ & \\
\hline & $\Delta F$ & $67.28 * * *$ & & $122.30^{* * *}$ & & $82.75^{* * *}$ & \\
\hline India & Step 1 & & & & & & \\
\hline 92) & Fear of Islam & $.27 * *(0.09)$ & .29 & $.14(0.08)$ & .16 & $.27 * *(0.09)$ & .28 \\
\hline & Fear of Muslims & $-.11(0.11)$ & -.12 & $-.09(0.09)$ & -.10 & $-.04(0.10)$ & -.04 \\
\hline & $R^{2}$ & $.47 * *$ & & $.51 * *$ & & $.56^{* *}$ & \\
\hline & Step 2 & & & & & & \\
\hline & Anger toward Islam & $.32 *(0.13)$ & .34 & $.17(0.11)$ & .20 & $.05(0.12)$ & .05 \\
\hline & Anger toward Muslims & $.28(0.15)$ & .30 & $.34 * *(0.13)$ & .38 & $.54 * * *(0.14)$ & .55 \\
\hline & $R^{2}$ & $.56^{* *}$ & & $.64 * *$ & & $.65^{* *}$ & \\
\hline & $\Delta R^{2}$ & $.09 * *$ & & $.13^{* *}$ & & $.08^{* *}$ & \\
\hline & Step 3 & & & & & & \\
\hline & Disgust toward Islam & $0.16(0.14)$ & .17 & $0.20(0.11)$ & .23 & $0.20(0.13)$ & .21 \\
\hline & Disgust toward Muslims & $-.20(0.15)$ & --.21 & $-.04(0.13)$ & -.04 & $-.20(0.14)$ & -.20 \\
\hline
\end{tabular}


SUPPLEMENTAL ONLINE MATERIALS: NATURE OF ISLAMOPHOBIA

$\begin{array}{cccc}R^{2} & .56^{* *} & .64^{* *} & .65^{* *} \\ \Delta R^{2} & .00 & .00 & .00 \\ \Delta F & 60.69^{* * *} & 85.55^{* * *} & 89.92^{* * *}\end{array}$

Note. All standardized estimates are from the last step of the analyses.

$* p<.05 . * * p<.01 .{ }^{* * *} p<.001$. 
SUPPLEMENTAL ONLINE MATERIALS: NATURE OF ISLAMOPHOBIA

Table S8

Study 1 - Single-Country Confirmatory Factor Analysis: Global Fit Measures for One-Factor, Two-Factor, and Three-Factor Islamophobia Models (USA, Germany, Poland, France and India) $N=1466$.

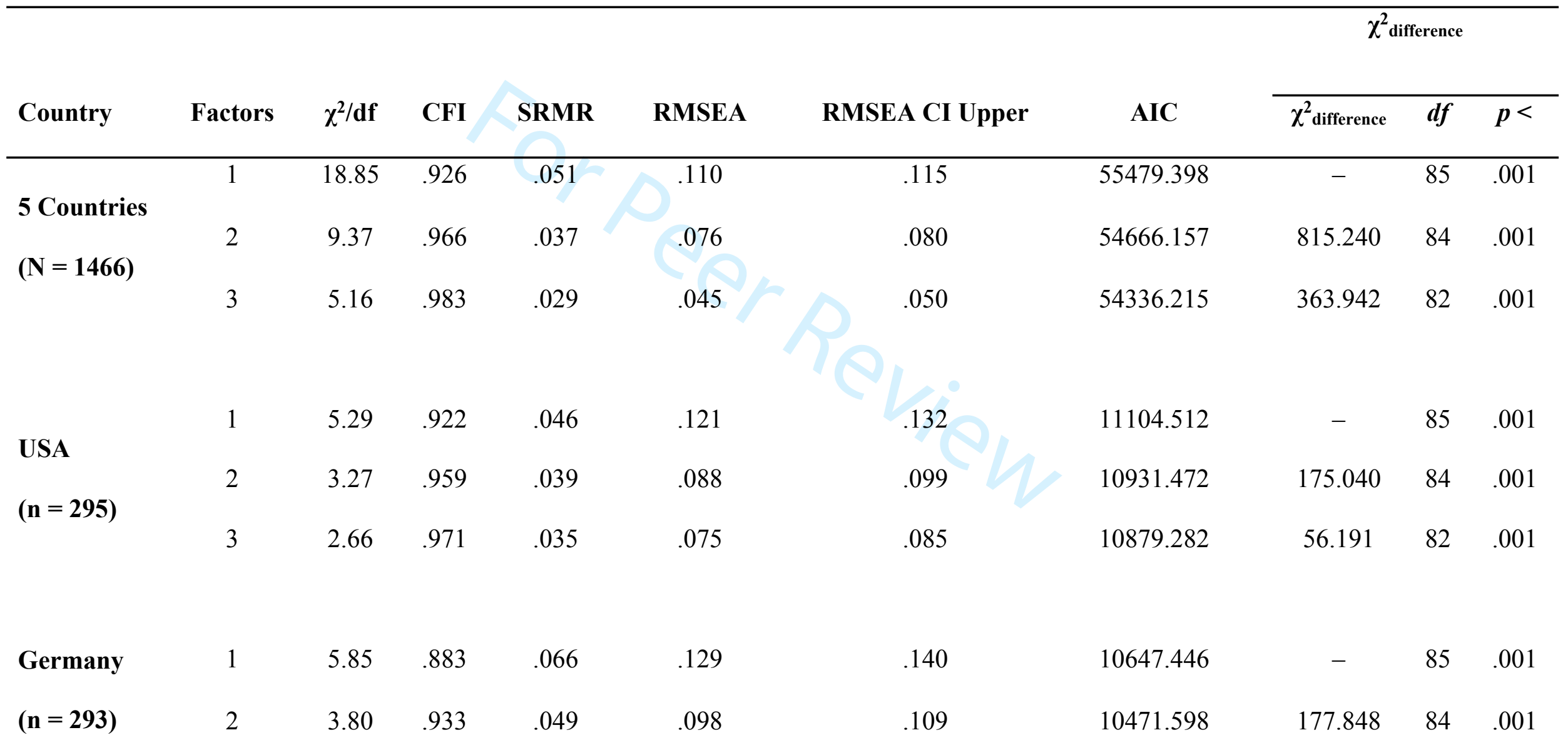


SUPPLEMENTAL ONLINE MATERIALS: NATURE OF ISLAMOPHOBIA

\begin{tabular}{|c|c|c|c|c|c|c|c|c|c|c|}
\hline & 3 & 2.15 & .973 & .032 & .063 & .075 & 10332.078 & 143.520 & 82 & .001 \\
\hline Poland & 1 & 3.25 & .926 & .055 & .087 & .099 & 11770.263 & - & 85 & .001 \\
\hline \multirow{2}{*}{$(n=297)$} & 2 & 2.37 & .956 & .047 & .068 & .080 & 11695.090 & 77.173 & 84 & .001 \\
\hline & 3 & 1.80 & .975 & .042 & .052 & .065 & 11647.754 & 51.337 & 82 & .001 \\
\hline France & 1 & 4.01 & .930 & .054 & .102 & .114 & 10128.309 & - & 85 & .001 \\
\hline \multirow{2}{*}{$(n=289)$} & 2 & 2.26 & .971 & .036 & .066 & .078 & 9980.882 & 151.421 & 84 & .001 \\
\hline & 3 & 1.82 & .982 & .032 & .053 & .067 & 9943.370 & 40.427 & 82 & .001 \\
\hline India & 1 & 5.15 & .925 & .047 & .119 & .130 & 10990.176 & - & 85 & .001 \\
\hline \multirow{2}{*}{$(n=292)$} & 2 & 3.04 & .963 & .038 & .084 & .096 & 10809.444 & 182.281 & 84 & .001 \\
\hline & 3 & 2.68 & .971 & .037 & .076 & .088 & 10777.403 & 36.345 & 82 & .001 \\
\hline
\end{tabular}

Notes. Robust SEM Model-fit (Satorra-Bentler correction; Mplus Variant).

The One-Factor Model was constructed with all items representing one latent factor. In the Two-Factor Model, all items referring to Islam constituted on latent variable and all items referring to Muslims formed a second latent variable. In the Three-Factor Model, the proposed tripartite 


\section{SUPPLEMENTAL ONLINE MATERIALS: NATURE OF ISLAMOPHOBIA}

structure was modelled representing anti-Muslim prejudice, anti-Islam sentiment, and conspiracy beliefs. We also tested all possible two-factor models. The results can be found in Table S9 in this file. As reported in Table S8, single country CFAs indicated acceptable modification indices (CFI, AIC, SRMR, RMSEA) with only India and the USA showing RMSEA values slightly above the threshold of .080 (USA: RMSEA =0.085; India: $R M S E A=0.088)$. Hence, a few modifications were applied to achieve better fit of the models for the remaining analysis. In order to improve the model fit indices for the models, we explored the modification indices in each country sample. Additional covariances were introduced into the models in theoretically justified and significant cases $\left(\chi^{2}\right.$ difference $\left.>10\right)$ among the modification indices. We allowed error items of the same latent constructs, but not between items measuring different latent constructs to covary, resulting in the re-specification of five parameters for the overall sample in total: one residual covariance for anti-Islamic sentiment (Isl_4 Isl_5); one residual covariance for anti-Muslim prejudice (Musl_1 Musl_3), and three residual covariances for conspiracy beliefs (Consp_3 Consp_5; Consp_2 Consp_3 + Consp_5). The MI analysis was conducted including these re-specifications. 


\section{SUPPLEMENTAL ONLINE MATERIALS: NATURE OF ISLAMOPHOBIA}

Table S9

Study 1 - Single-Country Confirmatory Factor Analysis: Global Fit Measures for all Alternative Two-Factor Combinations of the Islamophobia Model (USA, Germany, Poland, France and India; $N=1466)$.

\section{$\chi^{2}$ difference}

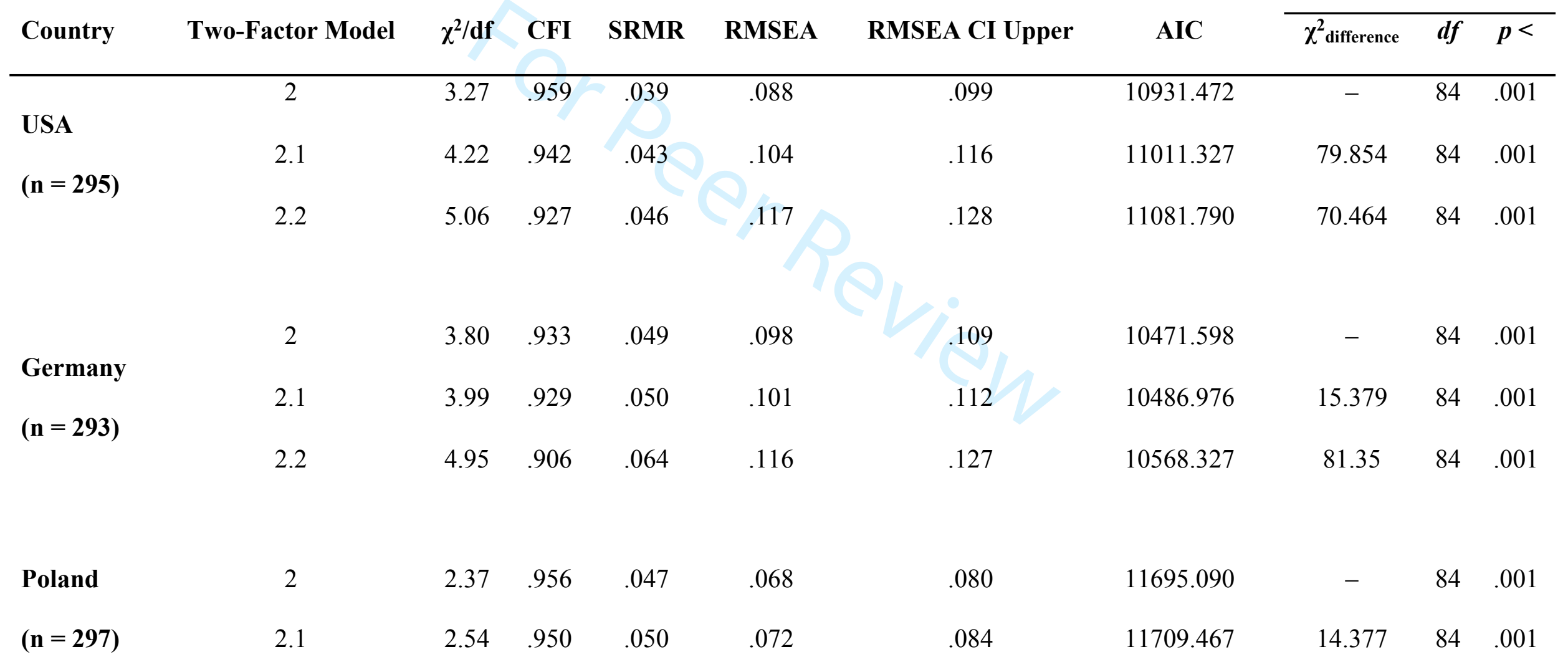


SUPPLEMENTAL ONLINE MATERIALS: NATURE OF ISLAMOPHOBIA

France

$(n=289)$
India

$(\mathrm{n}=\mathbf{2 9 2})$

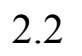

2.1

2.2
$2.87 \quad .940$

.052

$2.26 \quad .971 \quad .036$

.079

.066

$3.27 \quad .948$

$3.73 \quad .938$

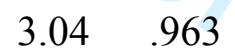

.038

.084

$4.11 \quad .944$

.046

$4.88 \quad .930$

.047
.091

11736.602

27.135

84

.001

Notes. Robust SEM Model-fit (Satorra-Bentler correction; Mplus Variant).

In the first Two-Factor Model (2), all items referring to Islam constituted on latent variable and all items referring to Muslims (anti-Muslim

Prejudice and conspiracy beliefs) formed a second latent variable (this version, which showed the best fit to data, was also used as comparative twofactor model in the main analysis (see Table S8 in this file). The second Two-Factor Model (2.1) was constructed with anti-Muslim prejudice items and anti-Islam sentiment items representing one latent factor and conspiracy belief items representing the second latent factor. In the third Two-

Factor Model (2.2) items from anti-Islam sentiment and conspiracy beliefs components formed one latent factor, while anti-Muslim prejudice formed the second latent variable. 


\section{SUPPLEMENTAL ONLINE MATERIALS: NATURE OF ISLAMOPHOBIA}

Table S10

Regression results using the Tripartite Islamophobia Scale as the Criterion Variable $(n=1466)$.

\begin{tabular}{|c|c|c|c|c|c|c|c|c|c|c|}
\hline Country & Predictor & $\boldsymbol{b}$ & $\begin{array}{c}b \\
95 \% \text { CI } \\
{[L L, U L]}\end{array}$ & beta & $\begin{array}{c}\text { beta } \\
95 \% \text { CI } \\
{[\mathrm{LL}, \mathrm{UL}]} \\
\end{array}$ & $s r^{2}$ & $\begin{array}{c}s r^{2} \\
95 \% \text { CI } \\
{[L L, \text { UL] }}\end{array}$ & $r$ & Fit & Difference \\
\hline \multirow{12}{*}{$\begin{array}{l}5 \text { Countries } \\
(\mathrm{N}=1466)\end{array}$} & Step 1 & & & & & & & & & \\
\hline & (Intercept) & $1.23 * *$ & {$[1.15,1.30]$} & & & & & & Adj. $R^{2}=.574^{* *}$ & \\
\hline & Fear Islam \& Muslims & $0.68 * *$ & {$[0.65,0.71]$} & 0.76 & {$[0.72,0.79]$} & .57 & {$[.54, .60]$} & $.76^{* *}$ & $95 \%$ CI $[.54, .60]$ & \\
\hline & Step 2 & & & & & & & & & \\
\hline & (Intercept) & $1.03 * *$ & {$[0.96,1.10]$} & & & & & & $A d i R^{2}=687 * *$ & $\Delta R^{2}=1+1$ \\
\hline & Fear Islam \& Muslims & $0.28 * *$ & {$[0.24,0.33]$} & 0.32 & {$[0.27,0.37]$} & .04 & {$[.03, .05]$} & $.76^{* *}$ & & \\
\hline & Anger Islam \& Muslims & $0.52 * *$ & {$[0.47,0.56]$} & 0.55 & {$[0.51,0.60]$} & .11 & {$[.09, .13]$} & $.81 * *$ & 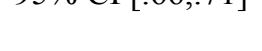 & ] \\
\hline & Step 3 & & & & & & & & & \\
\hline & (Intercept) & $1.03 * *$ & {$[0.96,1.09]$} & & & & & & & \\
\hline & Fear Islam \& Muslims & $0.28 * *$ & {$[0.24,0.32]$} & 0.32 & {$[0.27,0.36]$} & .04 & {$[.03, .05]$} & $.76^{* *}$ & Adj. $R^{2}=.689 * *$ & $\Delta R^{2}=.002 * *$ \\
\hline & Anger Islam \& Muslims & $0.44 * *$ & {$[0.36,0.51]$} & 0.46 & {$[0.39,0.54]$} & .03 & {$[.02, .04]$} & $.81 * *$ & $95 \%$ CI $[.67, .71]$ & $95 \%$ CI $[-.00, .00]$ \\
\hline & Disgust Islam \& Muslims & $0.10^{* *}$ & {$[0.03,0.16]$} & 0.10 & {$[0.03,0.17]$} & .00 & {$[-.00, .00]$} & $.76^{* *}$ & & \\
\hline \multirow{3}{*}{$\begin{array}{l}\text { USA } \\
(n=295)\end{array}$} & Step 1 & & & & & & & & & \\
\hline & (Intercept) & $1.05^{* *}$ & {$[0.88,1.21]$} & & & & & & Adj. $R^{2}=.616^{* *}$ & \\
\hline & Fear Islam \& Muslims & $0.72 * *$ & {$[0.66,0.79]$} & 0.78 & {$[0.71,0.86]$} & .62 & {$[.55, .67]$} & $.78 * *$ & $95 \%$ CI $[.55, .67]$ & \\
\hline
\end{tabular}

Step 2 


\section{SUPPLEMENTAL ONLINE MATERIALS: NATURE OF ISLAMOPHOBIA}

\begin{tabular}{llllllllll} 
(Intercept) & $0.90^{* *}$ & {$[0.75,1.04]$} & & & & & \multicolumn{3}{c}{ Adj. $R^{2}=.706^{* *}$} \\
Fear Islam \& Muslims & $0.27^{* *}$ & {$[0.17,0.38]$} & 0.30 & {$[0.18,0.42]$} & .02 & {$[.00, .04]$} & $.78^{* *}$ & $95 \%$ CI $[.65, .75]$ & $\Delta R^{2}=.091^{* *}$ \\
Anger Islam \& Muslims & $0.55^{* *}$ & {$[0.44,0.67]$} & 0.57 & {$[0.45,0.69]$} & .09 & {$[.05, .13]$} & $.83^{* *}$ & & $95 \%$ CI $[.05, .13]$
\end{tabular}

\section{Step 3}

(Intercept)

$0.90^{* *} \quad[0.75,1.04]$

Fear Islam \& Muslims

$0.28^{* *} \quad[0.17,0.39]$

Anger Islam \& Muslims

$0.58 * * \quad[0.39,0.76]$

0.30

$[0.18,0.42] \quad .02 \quad[.00, .04] \quad .78^{* *}$

Adj. $R^{2}=.706^{* *}$

$\Delta R^{2}=.000$

Disgust Islam \& Muslims

$-0.03$

$[-0.21,0.15]$

$-0.03$

$[0.41,0.79]$

.04

$[.01, .06] \quad .83^{* *}$

$95 \%$ CI $[.65,74]$

$95 \% \mathrm{CI}[-.00, .00]$

\section{Germany Step 1}

$(\mathbf{n}=\mathbf{2 9 3}) \quad$ (Intercept)

Fear Islam \& Muslims

$1.19^{* *} \quad[1.01,1.36]$

$0.67 * * \quad[0.58,0.76]$

0.66

$[0.57,0.75]$

.43

$[.35, .50]$

$.66^{* *}$

Adj. $R^{2}=.434 * *$

$95 \%$ CI $[.35, .50]$

\section{Step 2}

(Intercept)

$0.90^{* *} \quad[0.75,1.04]$

Fear Islam \& Muslims

Anger Islam \& Muslims

$0.19^{* *}$

$[0.09,0.29]$

$0.64 * *$

$[0.55,0.74]$

0.19

$[0.09,0.29]$

0.66

$[0.56,0.76]$

.02

$[-.00, .04] \quad .66^{* *}$

Adj. $R^{2}=.644 * *$

$\Delta R^{2}=.210^{* *}$

\section{Step 3}

(Intercept)

$0.86^{* *} \quad[0.71,1.00]$

Fear Islam \& Muslims

Anger Islam \& Muslims

$0.20^{* *}$

$[0.10,0.30]$

$0.36^{* *} \quad[0.22,0.50]$

0.20

$[0.10,0.29]$

.02

$[.00, .04] \quad .66^{* *}$

Adj. $R^{2}=.676^{* *}$

$\Delta R^{2}=.032 * *$

Disgust Islam \& Muslims

$0.34^{* *}$

$[0.22,0.47]$

0.34

$[0.23,0.5$

$[.01, .05] \quad .79 * *$

$95 \%$ CI $[.62, .72]$

$95 \%$ CI $[.01, .06]$ 


\section{SUPPLEMENTAL ONLINE MATERIALS: NATURE OF ISLAMOPHOBIA}

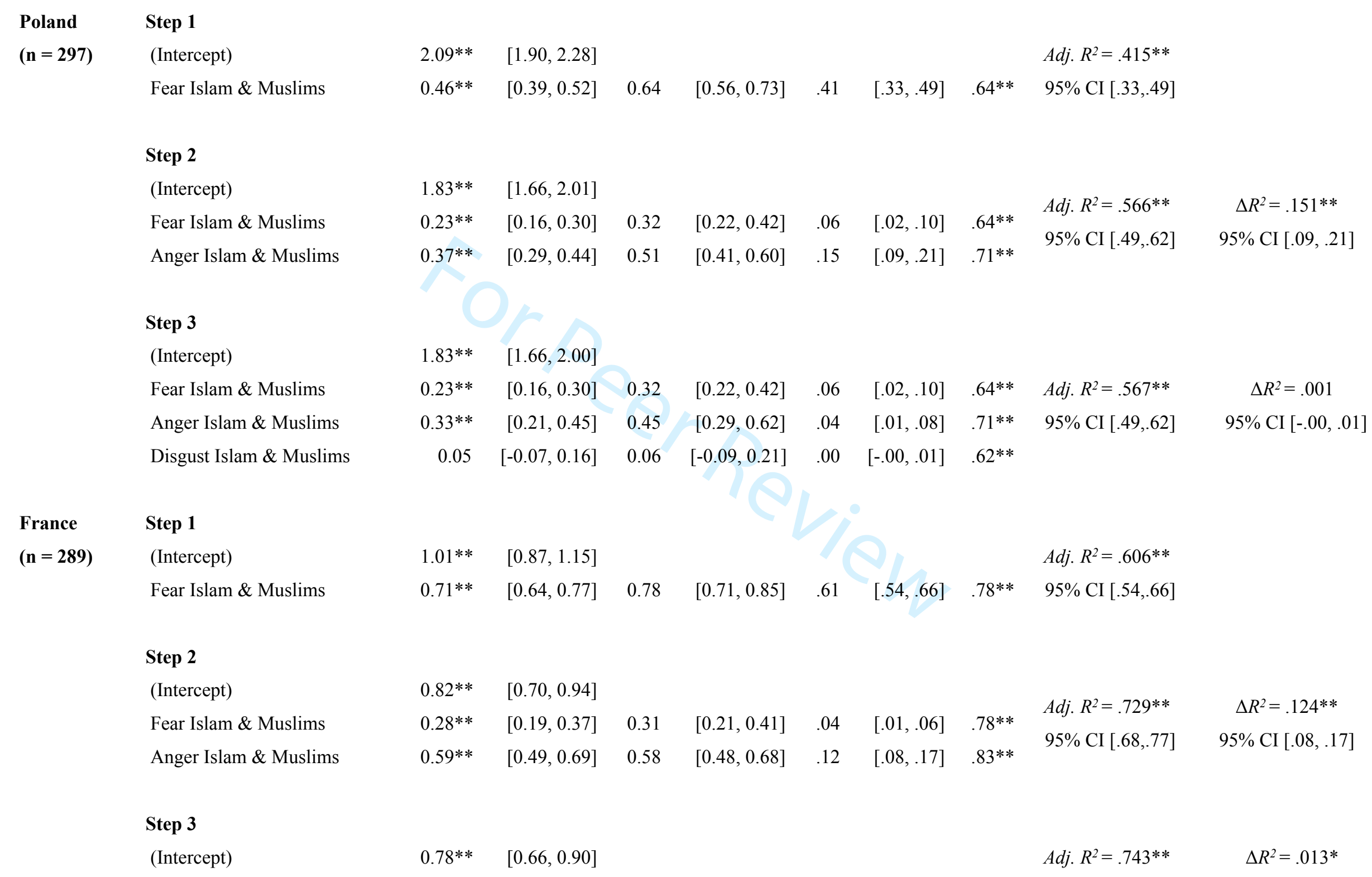




\section{SUPPLEMENTAL ONLINE MATERIALS: NATURE OF ISLAMOPHOBIA}

$\begin{array}{llllllllll}\text { Fear Islam \& Muslims } & 0.28^{* *} & {[0.19,0.37]} & 0.31 & {[0.21,0.41]} & .03 & {[.01, .06]} & .78^{* *} & 95 \% \text { CI }[.69, .78] & 95 \% \text { CI }[.00, .03] \\ \text { Anger Islam \& Muslims } & 0.34^{* *} & {[0.18,0.50]} & 0.34 & {[0.18,0.50]} & .02 & {[.00, .03]} & .83^{* *} & & \\ \text { Disgust Islam \& Muslims } & 0.30^{* *} & {[0.15,0.45]} & 0.28 & {[0.13,0.42]} & .01 & {[-.00, .03]} & .81^{* *} & & \end{array}$

\section{India Step 1}

$(\mathbf{n}=\mathbf{2 9 2}) \quad$ (Intercept)

\section{$1.30^{* *} \quad[1.13,1.47]$}

Fear Islam \& Muslims

$0.67^{*}$

$[0.60,0.73]$

0.76

$[0.69,0.84]$

.58

$[.51, .64]$

Adj. $R^{2}=.582^{* *}$

\section{Step 2}

(Intercept)

Fear Islam \& Muslims

Anger Islam \& Muslims

$\begin{array}{lll}1.13^{* *} & {[0.98,1.28]} & \\ 0.18^{* *} & {[0.07,0.29]} & 0.20 \\ 0.58^{* *} & {[0.47,0.70]} & 0.65\end{array}$

$[0.08,0.33]$

$[0.52,0.78]$

.01

$[-.00, .02]$

$.76^{* *}$

Adj. $R^{2}=.688^{* *}$

$\Delta R^{2}=.105^{* *}$

\section{Step 3}

(Intercept)

$1.13^{* *} \quad[0.98,1.28]$

Fear Islam \& Muslims

Anger Islam \& Muslims

$0.18^{* *} \quad[0.06,0.29]$

$0.55^{* *} \quad[0.34,0.77] \quad 0.61$

[0.07, 0.33]

$.01 \quad[-.00, .02] \quad .76^{* *}$

Adj. $R^{2}=.688^{* *}$

$\Delta R^{2}=.000$

Disgust Islam \& Muslims

0.03

$[-0.17,0.24]$

0.04

$[-0.19,0.27]$

$.00 \quad[-.00, .00] \quad .80^{* *}$

$95 \%$ CI $[.63, .73]$

$95 \%$ CI $[-.00, .00]$

Note. A significant $b$-weight indicates the beta-weight and semi-partial correlation are also significant. $b$ represents unstandardized regression weights. beta indicates the standardized regression weights. $s r^{2}$ represents the semi-partial correlation squared. $r$ represents the zero-order correlation. $L L$ and $U L$ indicate the lower and upper limits of a confidence interval, respectively.

$* p<.05 . * * p<.01$. 


\section{SUPPLEMENTAL ONLINE MATERIALS: NATURE OF ISLAMOPHOBIA}

Table S11

Regression Results Using the Tripartite Islamophobia Subscales as the Criterion Variables.

\begin{tabular}{|c|c|c|c|c|c|c|c|}
\hline \multirow[t]{2}{*}{ Country } & \multirow[t]{2}{*}{ Intergroup emotions } & \multicolumn{2}{|c|}{ Anti-Islam Sentiment } & \multicolumn{2}{|c|}{ Anti-Muslim Prejudice } & \multicolumn{2}{|c|}{ Conspiracy Beliefs } \\
\hline & & $B(\mathrm{SE})$ & $\beta$ & $B(\mathrm{SE})$ & $\beta$ & $B(\mathrm{SE})$ & $\beta$ \\
\hline \multirow{13}{*}{$\begin{array}{l}5 \text { Countries } \\
(N=1466)\end{array}$} & Step 1 & & & & & & \\
\hline & Fear & $.27 * * *(0.03)$ & .25 & $.24 * * *(0.02)$ & .26 & $.35 * * *(0.03)$ & .35 \\
\hline & $R^{2}$ & $.43 * *$ & & $.52 * *$ & & $.51 * *$ & \\
\hline & Step 2 & & & & & & \\
\hline & Anger & $.50 * * *(0.05)$ & .50 & $.49 * * *(0.04)$ & .49 & $.31 * * *(0.05)$ & .30 \\
\hline & $R^{2}$ & $.52 * *$ & & $.64 * *$ & & $.59 * *$ & \\
\hline & $\Delta R^{2}$ & $.09 * *$ & & $.12 * *$ & & $.08 * *$ & \\
\hline & Step 3 & & & & & & \\
\hline & Disgust & $-.01(0.04)$ & -.01 & $.10 * *(0.04)$ & .10 & $.20 * * *(0.04)$ & .18 \\
\hline & $R^{2}$ & $.52 * *$ & & $.65 * *$ & & $.60 * *$ & \\
\hline & $\Delta R^{2}$ & .00 & & $.01 * *$ & & $.01 * *$ & \\
\hline & $\Delta F$ & $529.00 * * *$ & & $891.30 * * *$ & & $722.10 * * *$ & \\
\hline & Step 1 & & & & & & \\
\hline \multirow{6}{*}{$\begin{array}{l}\text { USA } \\
(n=295)\end{array}$} & Fear & $.28 * * *(0.07)$ & .29 & $.20 * * *(0.06)$ & .21 & $.35 * * *(0.07)$ & .35 \\
\hline & $R^{2}$ & $.50 * *$ & & $.56 * *$ & & $.56 * *$ & \\
\hline & Step 2 & & & & & & \\
\hline & Anger & $.65 * * *(0.12)$ & .63 & $.57 * * *(0.10)$ & .56 & $.52 * * *(0.12)$ & .48 \\
\hline & $R^{2}$ & $.57 * *$ & & $.66^{* *}$ & & $.62 * *$ & \\
\hline & $\Delta R^{2}$ & $.07 * *$ & & $.10 * *$ & & $.06^{* *}$ & \\
\hline
\end{tabular}


SUPPLEMENTAL ONLINE MATERIALS: NATURE OF ISLAMOPHOBIA

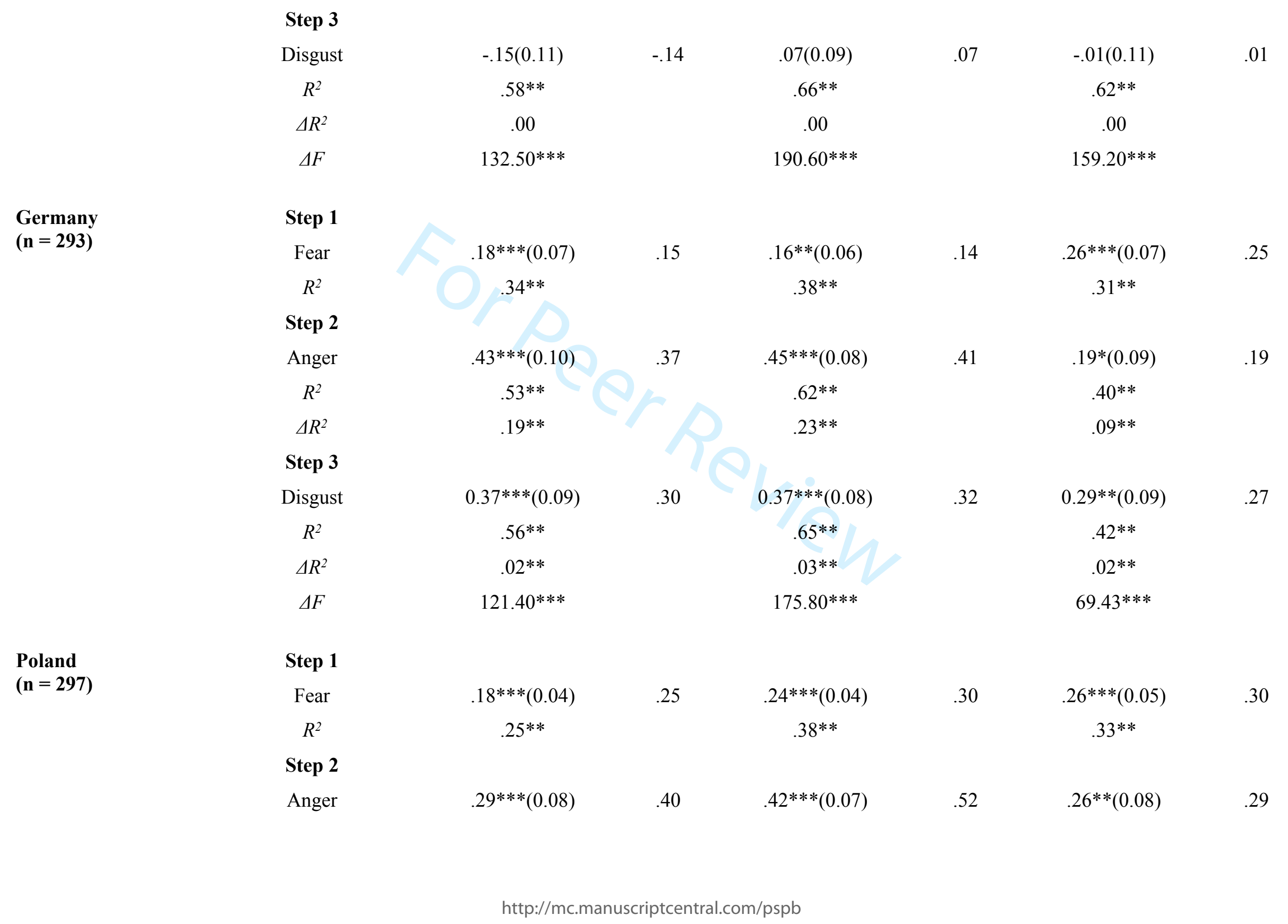


SUPPLEMENTAL ONLINE MATERIALS: NATURE OF ISLAMOPHOBIA

\begin{tabular}{|c|c|c|c|c|c|c|c|}
\hline & $R^{2}$ & $.34 * *$ & & $.53 * *$ & & $.45^{* *}$ & \\
\hline & $\Delta R^{2}$ & $.09 * *$ & & $.15^{* *}$ & & $.12 * *$ & \\
\hline & Step 3 & & & & & & \\
\hline & Disgust & $-0.00(0.07)$ & -.01 & $-0.02(0.06)$ & -.03 & $0.16 *(0.08)$ & .18 \\
\hline & $R^{2}$ & $.34 * *$ & & $.53 * *$ & & $.46^{* *}$ & \\
\hline & $\Delta R^{2}$ & .00 & & .00 & & $.01^{*}$ & \\
\hline & $\Delta F$ & $50.46 * * *$ & & $109.80^{* * *}$ & & $82.78 * * *$ & \\
\hline France & Step 1 & & & & & & \\
\hline$(n=289)$ & Fear & $.28 * * *(0.07)$ & .28 & $.23 * * *(0.05)$ & .24 & $.33 * * *(0.06)$ & .31 \\
\hline & $R^{2}$ & $.43 * *$ & & $.55^{* *}$ & & $.52 * *$ & \\
\hline & Step 2 & & & & & & \\
\hline & Anger & $.48 * * *(0.12)$ & .43 & $.30 * * *(0.09)$ & .28 & $.25 *(0.11)$ & .21 \\
\hline & $R^{2}$ & $.51 * *$ & & $.69 * *$ & & $.62 * *$ & \\
\hline & $\Delta R^{2}$ & $.08^{* *}$ & & $14 * *$ & & $.09 * *$ & \\
\hline & Step 3 & & & & & & \\
\hline & Disgust & $0.05(0.11)$ & .04 & $0.43 * * *(0.08)$ & .38 & $0.42 * * *(0.11)$ & .33 \\
\hline & $R^{2}$ & $.51^{* *}$ & & $.72 * *$ & & $.64^{* *}$ & \\
\hline & $\Delta R^{2}$ & .00 & & $.03 * *$ & & $.02 * *$ & \\
\hline & $\Delta F$ & $101.10^{* * *}$ & & $244.20 * * *$ & & $166.90 * * *$ & \\
\hline India & Step 1 & & & & & & \\
\hline$(n=292)$ & Fear & $.19 *(0.08)$ & .21 & $.07(0.06)$ & .08 & $.25 * * *(0.07)$ & .26 \\
\hline & $R^{2}$ & $.46^{* *}$ & & $.51 * *$ & & $.56^{* *}$ & \\
\hline
\end{tabular}


SUPPLEMENTAL ONLINE MATERIALS: NATURE OF ISLAMOPHOBIA

$\begin{array}{cc}\text { Step 2 } & \\ \text { Anger } & .62 * * *(0.14) \\ R^{2} & .54 * * \\ \Delta R^{2} & .08^{* *}\end{array}$

\section{Step 3}

Disgust

$-0.09(0.14)$

$-.10$

$0.16(0.11)$

$.54 * *$

$.64^{* *}$

$(0.12)$

$.64 * *$

$\Delta R^{2}$

.00

.00

.00

$\Delta F$

$112.60 * * *$

$168.90 * * *$

$174.70^{* * *}$

Note. All standardized estimates are from the last step of the analyses.

${ }^{*} p<.05 .{ }^{* *} p<.01 .{ }^{* * *} p<.001$. 


\section{SUPPLEMENTAL ONLINE MATERIALS: NATURE OF ISLAMOPHOBIA}

Table S12

Means, Standard Deviations, Scales, and Intercorrelations Between Variables ( $N=213$, USA: Sample 6).

\begin{tabular}{|c|c|c|c|c|c|c|c|c|c|c|c|c|c|c|c|c|c|}
\hline & $M$ & $(S D)$ & 1 & 2 & 3 & 4 & 5 & 6 & 7 & 8 & 9 & 10 & 11 & 12 & 13 & 14 & 15 \\
\hline 1. Social dominance orientation & 2.01 & 0.97 & - & & & & & & & & & & & & & & \\
\hline 2. Ingroup identification & 3.73 & 1.07 & $.26^{* *}$ & & & & & & & & & & & & & & \\
\hline 3. Political orientation & 2.13 & 1.42 & $.53 * *$ & $.34 * *$ & & & & & & & & & & & & & \\
\hline 4. Fear of Islam & 2.23 & 1.37 & $.39 * *$ & $.31 * *$ & $.33 * *$ & & & & & & & & & & & & \\
\hline 5. Fear of Muslims & 2.12 & 1.32 & $.45^{* *}$ & $.31 * *$ & $.45^{* *}$ & $.84 * *$ & & & & & & & & & & & \\
\hline 6. Anger toward Islam & 2.27 & 1.34 & $.43^{* *}$ & $.24 * *$ & $.40 * *$ & $.78 * *$ & $.70 * *$ & & & & & & & & & & \\
\hline 7. Anger toward Muslims & 1.98 & 1.23 & $.53 * *$ & $.28 * *$ & $.54 * *$ & $.72 * *$ & $.83^{* *}$ & $.81 * *$ & & & & & & & & & \\
\hline 8. Disgust of Islam & 2.17 & 1.34 & $.44^{* *}$ & $.22 * *$ & $.42 * *$ & $.75^{* *}$ & $.71 * *$ & $.93 * *$ & $.83 * *$ & & & & & & & & \\
\hline 9. Disgust of Muslims & 1.94 & 1.27 & $.55^{* *}$ & $.27 * *$ & $.50 * *$ & $.71 * *$ & $.79 * *$ & $.79 * *$ & $.94 * *$ & $.85^{* *}$ & & & & & & & \\
\hline 10. Fear of Islam \& Muslims & 2.17 & 1.29 & $.44 * *$ & $.32 * *$ & $.40 * *$ & $.96^{* *}$ & $.96 * *$ & $.77 * *$ & $.80 * *$ & $.76^{* *}$ & $.78 * *$ & & & & & & \\
\hline 11. Anger Islam \& Muslims & 2.12 & 1.23 & $.50 * *$ & $.27 * *$ & $.49 * *$ & $.79 * *$ & $.80 * *$ & $.96 * *$ & $.95^{* *}$ & $.93 * *$ & $.91 * *$ & $.83 * *$ & & & & & \\
\hline 12. Disgust Islam \& Muslims & 2.06 & 1.26 & $.51 * *$ & $.25^{* *}$ & $.47 * *$ & $.76^{* *}$ & $.78 * *$ & $.90 * *$ & $.91 * *$ & $.97 * *$ & $.96^{* *}$ & $.80 * *$ & $.95 * *$ & & & & \\
\hline 13. Anti-Islam Sentiment & 2.50 & 0.96 & $.36^{* *}$ & $.34 * *$ & $.43 * *$ & $.62 * *$ & $.61 * *$ & $.76^{* *}$ & $.70 * *$ & $.75^{* *}$ & $.66^{* *}$ & $.64 * *$ & $.77 * *$ & $.73 * *$ & & & \\
\hline 14. Anti-Muslim Prejudice & 2.08 & 0.97 & $.52 * *$ & $.37 * *$ & $.58 * *$ & $.67 * *$ & $.73 * *$ & $.71 * *$ & $.80^{* *}$ & $.73 * *$ & $.78 * *$ & $.73 * *$ & $.79 * *$ & $.78^{* *}$ & $.79 * *$ & & \\
\hline 15. Conspiracy-Beliefs & 2.38 & 1.36 & $.47 * *$ & $.34 * *$ & $.57 * *$ & $.66^{* *}$ & $.69 * *$ & $.73 * *$ & $.78 * *$ & $.75^{* *}$ & $.75^{* *}$ & $.71 * *$ & $.80 * *$ & $.78^{* *}$ & $.81 * *$ & $.87 * *$ & \\
\hline 16. Tripartite Islamophobia Scale & 2.35 & 1.04 & $.48 * *$ & $.37 * *$ & $.55 * *$ & $.70 * *$ & $.73 * *$ & $.78 * *$ & $.80 * *$ & $.78 * *$ & $.77 * *$ & $.75 * *$ & $.83 * *$ & $.80 * *$ & $.92 * *$ & $.94 * *$ & $.94 * *$ \\
\hline
\end{tabular}


SUPPLEMENTAL ONLINE MATERIALS: NATURE OF ISLAMOPHOBIA

Table S13

Study 2 - Single-Country Confirmatory Factor Analysis: Global Fit Measures for One-Factor, Two-Factor, and Three-Factor Islamophobia Models (USA) $N=213$.

$\chi^{2}$ difference

\begin{tabular}{|c|c|c|c|c|c|c|c|c|c|c|}
\hline \multirow{2}{*}{ Country } & \multirow[b]{2}{*}{ Factors } & \multirow{2}{*}{$\chi^{2 / d f}$} & \multirow{2}{*}{ CFI } & \multirow[b]{2}{*}{ SRMR } & \multirow[b]{2}{*}{ RMSEA } & \multirow[b]{2}{*}{ RMSEA CI Upper } & \multirow[b]{2}{*}{ AIC } & \multirow{2}{*}{$\chi_{\text {difference }}^{2}$} & \multirow[b]{2}{*}{$d f$} & \multirow{2}{*}{$p<$} \\
\hline & & & & & & & & & & \\
\hline \multirow{2}{*}{$\begin{array}{l}\text { USA } \\
(n=213)\end{array}$} & 2.1 & 2.82 & .936 & .041 & .092 & .127 & 7499.862 & 77.319 & 89 & .001 \\
\hline & 3 & 1.73 & .975 & .040 & .072 & .099 & 7356.948 & 177.854 & 87 & .001 \\
\hline
\end{tabular}

Notes. Robust SEM Model-fit (Satorra-Bentler correction; Mplus Variant).

The One-Factor Model was constructed with all items representing one latent factor. In the Two-Factor Model, all items referring to Islam constituted on latent variable and all items referring to Muslims formed a second latent variable. In the Three-Factor Model, the proposed tripartite structure was modelled representing anti-Muslim prejudice, anti-Islam sentiment, and conspiracy beliefs.

As in Study 1, we also tested all possible two-factor models. The first alternative Two-Factor Model (2.1) was constructed with anti-Muslim

prejudice items and anti-Islam sentiment items representing one latent factor and conspiracy belief items representing the second latent factor. In the 


\section{SUPPLEMENTAL ONLINE MATERIALS: NATURE OF ISLAMOPHOBIA}

second alternative Two-Factor Model (2.2) items from anti-Islam sentiment and conspiracy beliefs components formed one latent factor, while anti-

Muslim prejudice formed the second latent variable. 


\section{SUPPLEMENTAL ONLINE MATERIALS: NATURE OF ISLAMOPHOBIA}

Table S14

Translation of Intergroup Emotions into respective languages.

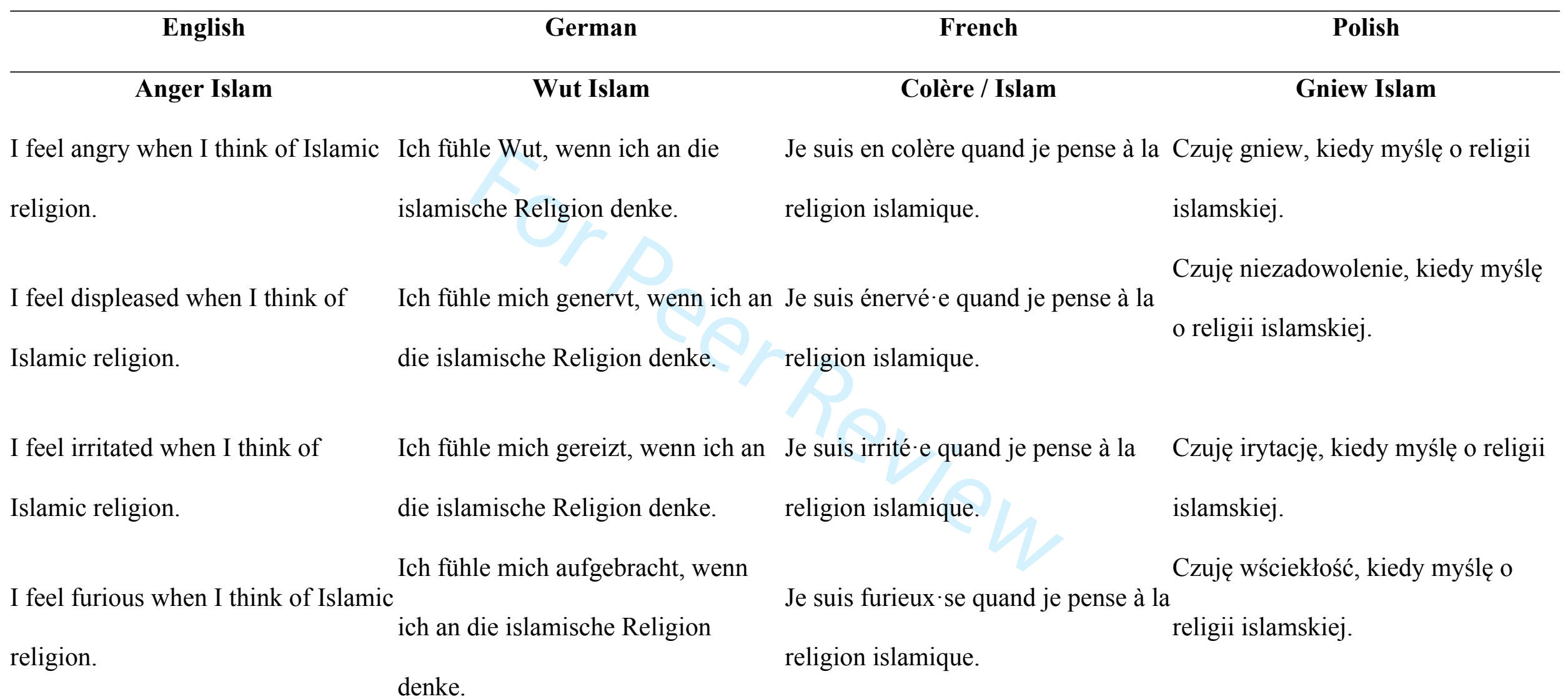

\section{Disgust Islam}

Ekel Islam

Dégoût / Islam

Obrzydzenie Islam 


\section{SUPPLEMENTAL ONLINE MATERIALS: NATURE OF ISLAMOPHOBIA}

I feel disgusted when I think of

Islamic religion.

I feel contemptuous when I think of Die islamische Religion empfinde

Islamic religion.

ich als verächtlich.

I feel repelled when I think of the

Islamic religion.

I feel sick when I think of the

Islamic religion.

\section{Fear Islam}

I feel afraid when I think of Islamic Ich fühle Angst, wenn ich an die religion. islamische religion denke.

I feel fearful when I think of Islamic Ich fühle mich ängstlich, wenn ich religion.

I feel worried when I think of

Islamic religion. an die islamische Religion denke.

Ich fühle mich besorgt, wenn ich an Je suis inquiet ète quand je pense à die islamische Religion denke. à la religion islamique.

religii islamskiej.

La religion islamique m'inspire de laCzuję pogardę, kiedy myślę o religii méfiance. islamskiej.

La religion islamique me répugne.

Czuję odrazę, kiedy myślę o religii islamskiej.

J'ai la nausée quand je pense à la Jest mi niedobrze, kiedy myślę o religion islamique. religii islamskiej.

\section{Peur / Islam}

\section{Strach Islam}

J'ai peur quand je pense à la religion Odczuwam strach, kiedy myślę o islamique.

religii islamskiej.

Je suis angoissé·e quand je pense à Odczuwam lęk, kiedy myślę o religii islamskiej.

Martwię się, kiedy myślę o religii

islamskiej. 


\section{SUPPLEMENTAL ONLINE MATERIALS: NATURE OF ISLAMOPHOBIA}

I feel anxious when I think of

Islamic religion.

Anger Muslims

I feel angry when I think of Muslim Ich fühle Wut, wenn ich an individuals.

I feel displeased when I think of

Muslim individuals.

I feel irritated when I think of

Muslim individuals.

I feel furious when I think of

Muslim individuals.

\section{Disgust Muslims}

Ich fühle mich beängstigt, wenn ich

an die islamische Religion denke.

Je suis apeuré·e quand je pense à la Odczuwam niepokój, kiedy myślę o

religii islamskiej.

\section{Gniew Muzułmanie}

Je ressens de la colère quand je

pense à des personnes musulmanes.

Czuję gniew, kiedy myślę o muslimische Personen denke.

Muzułmanach

Czuję niezadowolenie, kiedy myślę

Ich fühle mich genervt, wenn ich an Je suis énervé·e quand je pense à des

muslimische Personen denke. personnes musulmanes.

o Muzułmanach.

Ich fühle mich aufgebracht, wenn Je suis furieux·se quand je pense à Czuję wściekłość, kiedy myślę o

ich an muslimische Personen denke. des personnes musulmanes. Muzułmanach.
Ich fühle mich gereizt, wenn ich an Je suis irrité e quand je pense à des Czuję irytację, kiedy myślę o muslimische Personen denke. $\quad$ personnes musulmanes.

Muzułmanach. 


\section{SUPPLEMENTAL ONLINE MATERIALS: NATURE OF ISLAMOPHOBIA}

I feel disgusted when I think of Ich fühle Abscheu, wenn ich an Je ressens du dégoût quand je pense Czuję obrzydzenie, kiedy myślę o

Muslim individuals.

muslimische Personen denke.

à des personnes musulmanes.

Muzułmanach.

I feel contemptuous when I think of Muslimische Personen empfinde ich Les personnes musulmanes

Czuję pogardę, kiedy myślę o

Muslim individuals.

I feel repelled when I think of

Muslim individuals.

als verächtlich.

m’inspirent de la méfiance.

Muslimische Personen empfinde ich Les personnes musulmanes me

als abstossend.

répugnent.

I feel sick when I think of Muslim Ich fühle Übelkeit, wenn ich an individuals.

\section{Fear Muslims}

I feel afraid when I think of Muslim Ich fühle Angst, wenn ich an individuals. muslimische Personen denke.

I feel fearful when I think of Muslim Ich fühle mich ängstlich, wenn ich individuals.

I feel worried when I think of

Muslim individuals. an muslimische Personen denke.

Ich fühle mich besorgt, wenn ich an Je me sens inquiet ète quand je

muslimische Personen denke.
J'ai la nausée quand je pense à des personnes musulmanes.

\section{Peur / Musulmans}

J'ai peur quand je pense à des

personnes musulmanes.

Je me sens angoissé·e quand je

pense à des personnes musulmanes. Muzułmanach. pense à des personnes musulmanes. Muzułmanach.
Muzułmanach.

Czuję odrazę, kiedy myślę o

Muzułmanach.

Jest mi niedobrze, kiedy myślę o

Muzułmanach.

\section{Strach Muzułmanie}

Odczuwam strach, kiedy myślę o

Muzułmanach.

Odczuwam lęk, kiedy myślę o

Martwię się, kiedy myślę o 


\section{SUPPLEMENTAL ONLINE MATERIALS: NATURE OF ISLAMOPHOBIA}

I feel anxious when I think of

Muslim individuals.
Ich fühle mich beängstigt, wenn ich Je suis apeuré·e quand je pense à des Odczuwam niepokój, kiedy myślę o an Muslimische Personen denke. personnes musulmanes. 


\section{SUPPLEMENTAL ONLINE MATERIALS: NATURE OF ISLAMOPHOBIA}

Table S15

Translation of Tripartite Islamophobia Scale into respective languages.

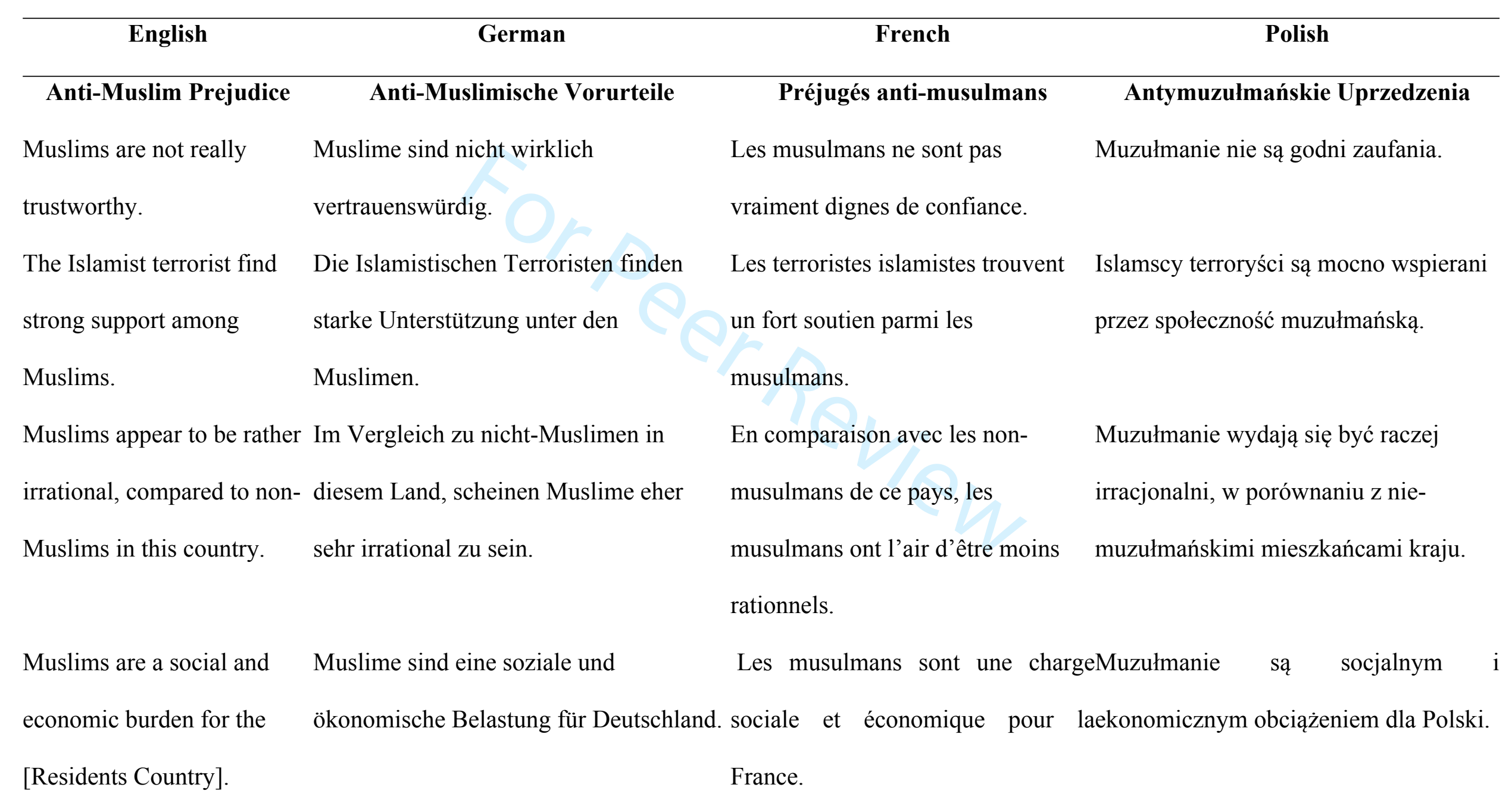




\section{SUPPLEMENTAL ONLINE MATERIALS: NATURE OF ISLAMOPHOBIA}

Muslims attract more $\quad$ Muslime fallen häufiger durch ihr

attention due to their

aggressive behavior.

Muslims are an enrichment Muslime sind eine Bereicherung für

for the [Residents

Country].*

Muslim practices fit

perfectly in our [Residents

Country].*

Anti-Islamic Sentiment

Anti-Islamisches Sentiment

Islam is a sexist religion. Die islamische Religion ist frauenfeindlich.

Islam is a violence- $\quad$ Die islamische Religion ist

glorifying religion.

aggressives Verhalten auf.
Muslimische Praktiken passen perfekt in Les pratiques musulmanes

s'intègrent parfaitement dans notre pasują do zachodniego świata.* monde occidental.*

\section{Sentiment anti-islamique}

\section{Antyislamskie opinie}

La religion islamique est hostile aux Religia islamska jest seksistowska. femmes.

La religion islamique glorifie la Religia islamska jest religią

violence. 


\section{SUPPLEMENTAL ONLINE MATERIALS: NATURE OF ISLAMOPHOBIA}

Islam is an antisemitic Der Islam ist eine antisemitische L'Islam est une religion antisémite. Religia islamska jest antysemicka.

religion.

Religion.

The Islamic religion is $\quad$ Die islamische Religion ist schädlich für La religion islamique menace la

Religia islamska działa na szkodę harmful for world peace. den Weltfrieden. paix dans le monde. światowego pokoju.

The Islamic religion is by

Die islamische Religion ist von seiner

La religion islamique, par sa nature, Religia islamska jest z założenia

default not compatible with Natur aus nicht vereinbar mit der

est incompatible avec la modernité. niespójna z nowoczesnością.

modernity.

Moderne.

Islam has produced an

Der Islam hat eine bewundernswerte

L'Islam a engendré une civilisation

Religia islamska stworzyła kulturę,

admirable culture.*

Kultur hervorgebracht.*

digne d'admiration.*

La religion islamique s'intègre

parfaitement à notre monde

occidental.*

Nation.*

Anti-Muslim Conspiracy

Islamophobe

Beliefs

Verschwörungstheorien
Théories du complot

islamophobes którą można podziwiać.*

Religia islamska pasuje do zachodniego

świata.*
Islamofobiczne

Teorie Spiskowe 


\section{SUPPLEMENTAL ONLINE MATERIALS: NATURE OF ISLAMOPHOBIA}

Muslims are planning to Muslime planen den Westen Schritt für Les musulmans ont pour but

Islamize the West step by Schritt zu Islamisie

step.

Actually, Muslims are

striving to establish the

Sharia in the [Residents

Country].

Muslims secretly plot for an Muslime streben insgeheim die

Islamization of the

[Residents Country].

Muslims would like to

control the international

political institutions.

Muslims achieve their

collective goals by secret

agreements.
Muzułmanie planują, krok po kroku,

d'islamiser progressivement

zislamizowanie zachodu.

l'Occident.

Secrètement, les musulmans

W tej chwili Muzułmanie usiłują

Scharia in Deutschland zu etablieren.

aspirent à établir la charia en

wprowadzić prawo Szariatu w Polsce.
Les musulmans aspirent secrètementMuzułmanie spiskują w celu

à l'islamisation de la France. $\quad$ zislamizowania Polski.

Les musulmans voudraient bien Muzułmanie chcieliby kontrolować

Muslime würden gerne die

contrôler les institutions politiques

międzynarodowe instytucje polityczne.

kontrollieren.

internationales.

Muslime erreichen ihre kollektiven Ziele Les musulmans atteignent leurs

Muzułmanie osiągają swoje wspólne durch geheime Absprachen

objectifs communs par des accords cele na drodze tajnych porozumień. 


\section{SUPPLEMENTAL ONLINE MATERIALS: NATURE OF ISLAMOPHOBIA}

Note. For the questionnaire used in India, we used the English version of the items. English language proficiency was a necessary requirement for the Amazon MTurk participants and participants were chosen accordingly using Amazon MTurk demographic information as well as indicating on the HIT board that English language proficiency was a necessary requirement. Additionally, we included an attention check in each survey to sort out non-sensical / random responses. Furthermore, some items in the Islamophobia construct were modified for the Indian context. Specifically, items referring to the "Western World" or "Western Culture" were changed to "India" or "Indian Culture." Similar to Amazon MTurk, PROLIFIC online academic research participant recruitment services provide the possibility to include/exclude specific socio-demographic target groups. To recruit only German, Polish, and French speaking candidates who live in either Germany, Poland, or France, the respective requirements were chosen from the online preset choices (birthplace, current country of residence, and native language).

* Reverse coded items

Consent Form, Debriefing Material, Online Study Description, and socio-demographic variables were also translated into the respective languages and can be obtained by the first author of this study. 


\section{SUPPLEMENTAL ONLINE MATERIALS: NATURE OF ISLAMOPHOBIA}

\section{References}

Little, T. D. (2013). Longitudinal structural equation modeling. New York, NY, US: Guilford Publications.

Meade, A. W., \& Bauer, D. J. (2007). Power and precision in confirmatory factor analytic tests of measurement invariance. Structural Equation Modeling, 14(4), 611-635. https://doi.org/10.1080/10705510701575461

Putnick, D. L., \& Bornstein, M. H. (2016). Measurement Invariance Conventions and Reporting: The State of the Art and Future Directions for Psychological Research. Developmental Review : DR, 41, 71-90. https://doi.org/10.1016/j.dr.2016.06.004

Schoemann, A. M., Boulton, A. J., \& Short, S. D. (2017). Determining Power and Sample Size for Simple and Complex Mediation Models. Social Psychological and Personality Science, 8(4), 379-386. https://doi.org/10.1177/1948550617715068 